$=$

failed

states

and

fragile

societies 
Failed States and Fragile Societies 



\title{
Failed States and Fragile Societies \\ A New World Disorder?
}

\author{
Ingo TrauschWEIZER \\ AND \\ Steven M. Miner \\ EDITORS
}

Ohio University Press

Athens 
Ohio University Press, Athens, Ohio 45701

ohioswallow.com

(C) 2014 by Ohio University Press

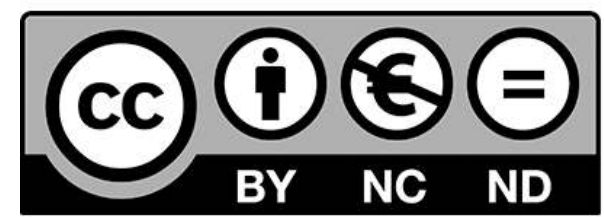

This work is licensed under the Creative Commons Attribution-NonCommercial-NoDerivs 4.0 (BY-NC-ND) which means that the text may be used for noncommercial purposes, provided credit is given to the author. For details go to http://creativecommons.orghicenses/by-nc-nd/4.o/.

\author{
Printed in the United States of America \\ Ohio University Press books are printed on acid-free paper. $\infty$ TM
}

201918171615141354321

Library of Congress Cataloging-in-Publication Data

Failed states and fragile societies : a new world disorder? /

edited by Ingo Trauschweizer, Steven M. Miner.

pages $\mathrm{cm}$. - (Baker series in peace and conflict studies)

Summary: "Since the end of the Cold War, a new dynamic has arisen within the international system, one that does not conform to established notions of the state's monopoly on war. In this changing environment, the global community must decide how to respond to the challenges posed to the state by military threats, political and economic decline, and social fragmentation. This insightful work considers the phenomenon of state failure and asks how the international community might better detect signs of state decay at an early stage and devise legally and politically legitimate responses. This collection of essays brings military and social historians into conversation with political and social scientists and former military officers. In case studies from the former Yugoslavia, Somalia, Iraq, and Colombia, the distinguished contributors argue that early intervention to stabilize social, economic, and political systems offers the greatest promise, whereas military intervention at a later stage is both costlier and less likely to succeed"- Provided by publisher.

Includes bibliographical references and index.

ISBN 978-0-8214-2090-4 (hardback) — ISBN 978-0-8214-2091-1 (pb) -

ISBN 978-0-8214-4488-7 (pdf)

1. Failed states-Case studies. 2. War. 3. Military policy. 4. Humanitarian assistance. 5. Human rights. 6. Conflict management--International cooperation. 7. Peaceful change (International relations) 8. Security, International. 9. World politics. I. Trauschweizer, Ingo. II. Miner, Steven Merritt, 1956-

JC328.7.F35 2014

$327.1-\mathrm{dc} 23$ 


\section{CONTENTS}

Introduction vii

Ingo Trauschweizer

\section{Part I: State Failure?}

1 The Future of War: Understanding Fragile States and What to Do about Them

David Carment and Yiagadeesen Samy

2 Human Rights and Wrongs in Failed States: Bosnia-Herzegovina, the International Community, and the Challenges of Long-Term Instability in Southeastern Europe

T. David Curp

\section{Part II: Using Force?}

3 The Past and Future of Insurgency: Protracted Warfare and Protracted Counterinsurgency Jonathan M. House

4 "The Lessons of the Last War Are Clear": The MilitaryIndustrial Complex, Private Contractors, and US Foreign Policy James M. Carter

5 Crime, Low-Intensity Conflict, and the Future of War in the Twenty-First Century

Vanda Felbab-Brown

\section{Part III: Systemic Response}

6 Odious and Failed States, Humanitarian Responses

Robert I. Rotberg

7 State Collapse and Local Response in Somalia

Ken Menkhaus

Postscript

Contributors

Index 



\title{
INTRODUCTION
}

\author{
INGO TRAUSCHWEIZER
}

Since the end of the Cold War, a dynamic has become apparent that does not conform to our deeply held notions of the state's monopoly of war. For example, the United States has been at war for a decade, but the wars in Afghanistan and Iraq do not entirely match our conventional understanding of what constitutes war. Do nonstate actors get to engage the armed forces of a great power as peer rivals? In the past two decades, the United Nations has underwritten more peacemaking or peacekeeping missions than in all of its prior history since 1945. Are these operations within the purview of war or peace? Students of war, violence, and the modern world have discovered a paradigm shift since the end of the Cold War, although it could be argued that the foundations of the old order started to crumble even as the Second World War came to a close in the Asia-Pacific theater. ${ }^{1}$ A school of thought is emerging that considers the wars of the late twentieth and early twenty-first centuries "new wars," defined by a burst of organized violence outside the framework of the state and its military. ${ }^{2}$ This may denote a new historical epoch, one in which the state's monopoly of significant violence, which had defined the political history of the West and the expansion of its empires since the seventeenth century, no longer applies. Anticolonial groups waging wars of national liberation had begun to erode that monopoly even in the earliest years of the Cold War era, but climactic events such as the Battle of Mogadishu in 1993 and the terrorist attacks on September 11, 2001, have served as stark and visual signs of a new age.

Western observers and policymakers have taken the state's monopoly of violence for granted, which has affected the ways in which they have related to instability and threats. A century ago, Max Weber defined the modern state as the sole legitimate wielder of power and violence. That definition was based on a long history of European princely states and nation-states that had 
developed ever greater bureaucratic reach since the early modern age, when fundamental changes in warfare and society led to centralized state power. There may be debate over whether "war made the state and the state made war," as the sociologist Charles Tilly famously proposed in the 1970s, but there can be little doubt about the power of the European state model and its global projection in the age of empire. ${ }^{3}$ And yet, while modern state structures also emerged outside of Europe, the monopoly of violence as fundamental definition hardly fit even the United States, surely a European offspring, until the First World War. ${ }^{4}$ And in Europe itself, the basis for legitimacy changed in the second half of the twentieth century from the warfare state to a civilian state, which thrives on economic integration and interdependency, on commerce and welfare, not on war. ${ }^{5}$ This suggests that successful states can be transformed, but it also suggests that both stability and prosperity are crucial pillars. Sadly, that leaves much of the world in a precarious position as the state's monopoly of violence has been eroded in the past decades.

The assumption of the post-Cold War years, following either realist theory or humanitarian instincts, that outside intervention could establish stability, which in turn would lead to a return of legitimate governmentideally in a democratic form-has proved to be tenuous at best. ${ }^{6}$ And yet, what is the global community to do when a regime collapses, as in Egypt; civil war erupts, as in Libya or Syria; ethnic tensions flare up, as in the former Yugoslavia; or warlords and rebel groups threaten the fabric of the state, as in Somalia and elsewhere in Africa? One response, traced in several contributions to this volume, asserts the responsibility of the global community to intervene and protect the population on the basis of the modern human rights regime. The question, however, also raised in these pages, is how to establish stability and legitimacy as outsiders and at what point and with what means to intervene. From the perspective of a military historian, it appears that the division of the world into a zone of peace and a zone of conflict is a rather grim reality that is based on the tremendous gap in prosperity more than it is rooted in political ideology or the desire to adjust borders that colonial powers once drew up too randomly. ${ }^{7}$ The fundamental question that needs to be considered carefully is what alternative sources of legitimacy exist for the state and for society.

How much anarchy in the international system can we tolerate? I suspect the answer would be none until we considered the flip side of the question: How much order can we afford to pay for? How should the West, or the United States, or the somewhat diffuse global community respond to the challenges posed to the state by military threats, political and economic decline, or social fragmentation? Idealists might propose primary emphasis on nongov- 
ernmental organizations that can operate in conflict zones or poor regions of the world without some of the encumbrance that comes with official diplomacy. Yet the commentator David Brooks surely has a point, even as he states it with some degree of polemics:

It's hard not to feel inspired by all these idealists, but their service religion does have some shortcomings. In the first place, many of these social entrepreneurs think they can evade politics. They have little faith in the political process and believe that real change happens on the ground beneath it. That's a delusion. You can cram all the nongovernmental organizations you want into a country, but if there is no rule of law and if the ruling class is predatory then your achievements won't add up to much. ${ }^{8}$

The ideal course of action, then, could be a combination of early recognition of sociopolitical, economic, or other fundamental crises, state and NGO engagement, and military intervention as a course of last resort.

At the Baker Peace Conference in the spring of 2011, scholars probed questions of failed and failing states, fragile and vulnerable societies, and the appropriate international response in contemporary history and in the present day. In his keynote address, Gen. Anthony Zinni, former commander of US Central Command and an astute observer of the greater Middle East and of matters of national and international security, presented a wide-ranging overview of the problem. From the perspective of the practitioner, as both a military professional and a peace mediator since his retirement from the Marine Corps, Zinni offered the fundamental lesson that the best intervention is an early intervention (i.e., he proposed that outside forces should invest in economic growth, education, and social and political stability to prevent states from failing and societies from fragmenting). He expressed great concern about the American propensity to deploy the armed forces as nationbuilders, which in Africa, Asia, and the Middle East has led to the image of an American as a uniformed soldier, while other foreigners are more likely to appear in the business attire of an investor, engineer, or educator. Zinni related his frustration as a regional commander with those in the United States who were not willing to authorize fairly limited spending on foreign aid, but would later support and underwrite much more expensive military operations. ${ }^{9}$

The problems that have led to the weakening and failure of states can stem from a depletion of natural resources, collapse of the legitimacy of a ruling party or individual leader, global economic developments, and a whole host of local issues. These are by no means new phenomena, but the apparent stability and binary nature of the Cold War tended to overshadow the poverty 
and erosion of power in much of the Third World. ${ }^{10}$ As General Zinni put it, during the Cold War both the United States and the Soviet Union "bought these problems off." Part of the payments arrived in the form of weapon systems that are still being used in the brutal wars in Eastern and Central Africa; and, of course, we are all too keenly aware of the indebtedness of Afghan mujahideen groups to the Carter and Reagan administrations, a fact that has not kept them from fighting NATO and notably the American occupiers with a ferocity similar to that with which they fought the Soviets in the 1980s. But these are the bigger wars in an age where organized violence below the level of interstate or even intrastate warfare threatens the nature and stability of the international system, where local warlords make common cause with crime syndicates, where smugglers help finance perpetual violence, and where business investments and much humanitarian aid is deflected into the coffers of the warring factions. And, most grimly, civilians make the most accessible and lucrative targets. Violence in weakening or failed states, in short, resembles "ethnic cleansing" more than it resembles "war"; and control over resources and territory relies on fear more than it depends on legitimate government.

It is critically important to assess the challenges posed by weakening states and fragmenting societies. What causes state failure? Can the symptoms be detected early enough and will the global community develop the political determination to act on that recognition? Should outside powers unilaterally intervene, or should the global community design intervention mechanisms? At the symposium a fault line became visible between historians and political and social scientists on these issues. The former suggested that every case is different and requires careful consideration that might, in some instances, lead to the decision to stay out of the downward spiral of a state because it is not apparent that intervention would do any good. The latter tended to emphasize the need to develop overarching policies that should be universally applicable. The surprise was the emergence of a consensus among those across disciplinary boundaries who study conditions in failing states that new sources of stability and legitimacy can evolve locally; that society in places like Somalia or Yemen may find ways to keep some villages, towns, or regions out of the vortex. And yet, from an international perspective, state failure poses a major threat not only to vulnerable people on the ground, but also to the world economy, if shipping routes see increased activity by pirates operating from bases in Somalia or Indonesia and Malaysia; and to international security, if terrorists find safe havens in Afghanistan, the autonomous tribal borderlands of Pakistan, or Yemen. Realists and idealists surely can find common ground in assessing the depth and the manifestations of the problem. Whether they 
can find common ground in advising policymakers to intervene, and how and when to do so, appears much less certain.

In part 1, David Carment and Yiagadeesen Samy present a rich and detailed global analysis of what constitutes a fragile state, while T. David Curp provides a case study of the convulsions of the wars in former Yugoslavia in the 1990s.

David Carment and Yiagadeesen Samy's collaboration highlights the malleability of terms such as "failed state" and "fragile state." The two authors suggest we should use the latter, which is more inclusive and perhaps also less controversial. Fragile states are on the brink of collapse in any oneor more- of three areas: effective and responsive governance, authority over people and territory, and capacity of the economy and of resource mobilization. Carment and Samy's research identifies anywhere from thirty to fifty fragile states around the world today that suffer from political, social, and economic instability, as well as from the lack of legitimacy of their authoritarian regimes. They note that there are similarities within regions: fragile states in sub-Saharan Africa are more likely to be faced by failing economies; the weakness and the vulnerability of Middle Eastern and South Asian states tend to stem from regimes that are often deemed illegitimate by significant parts of the populace. Drawing heavily on the statistical research of the Country Indicators for Foreign Policy project at Carleton University, Carment and Samy present three specific case studies-Haiti, Pakistan, and Yemen-that illustrate some of the different ways in which states can become vulnerable to a high degree of fragility. They argue that fragility of a state is an evolving process that should be closely monitored so that the international community can determine ways in which to help local actors. Carment and Samy conclude that doing so will require preparedness to engage early on in prevention rather than late in intervention, and it will require integrated research criteria across disciplines and policy-advice mechanisms across national borders.

T. David Curp reminds us of the wars of dissolution in the former Yugoslavia, a primary example of what Mary Kaldor has called "new wars," and he concludes that the optimism underlying Carment's study may be misplaced in particular cases. Specifically, Curp considers the aftermath of the brutal fighting in Bosnia-Herzegovina and the inherent difficulty of establishing a sovereign state in a territory comprising Bosnian Muslims, Serbs, and Croats, who continue to eye one another with great suspicion and hatred born from historical and recent experiences. Bosnia posed a challenge to outsiders who in principle wanted to intervene and stop the killing in the early 1990s, because it made plain that one of the foundational notions of humanitarian interventionism might not be universally applicable: we cannot assume that 
it is possible to separate enemy peoples, and we may have to face the reality that intervention requires choosing sides. Curp implies that what stability the 1995 Dayton Accords have helped to establish in Bosnia-Herzegovina may rest on the disquieting fact that most of the ethnic-cleansing projects of all combatants had in fact been completed by the time the political agreement was signed. He further argues that outside intervention, though driven by the best intentions and pursued in the name of human rights, has caused just as much harm as good in superimposing legal and political systems that do not fit the environment. Most pessimistically, Curp concludes that developments in Kosovo strongly suggest that the West's failure in Bosnia was not unique and that there are deeper underlying problems. It may be that the peculiar and particularly volatile mix of ancient hatreds, ethnic tensions, religious divides, and contemporary violence in the Balkans has shown us the outer limits of the modern human rights regime; but Curp suspects that reflexive humanitarian interventionism may be partially to blame, and he questions whether European leaders have thought through the consequences of their actions.

In part 2, Jonathan House, James Carter, and Vanda Felbab-Brown consider a range of responses, from humanitarian intervention and nation-building, to counterinsurgency and war, to the challenge posed to international security and human rights by state collapse.

Jonathan House, in an essay on the recent past and projected future of warfare, offers further insight into that unsettling question. House draws a careful distinction between insurgencies that are inspired by Mao Tse-tung's patient strategy of protracted war built on asymmetrical warfare by guerrillas or other local forces and older forms of "compound warfare," in which guerrillas operate alongside regular armed forces. The Vietnamese Communists, House suggests, offer a modern example for the latter. From a contemporary American perspective, of course, it is crucial to develop successful counterinsurgency methods. Here, House draws on historical examples that offer a range of responses, from brutal repression in dictatorships to the complex "Afghan math" at present, which highlights that indiscriminate killing of insurgents stokes the fires of the uprising. Fortunately, modern counterinsurgents have learned from the past and commonly apply an assumption that their insurgent foes are not all fighting for the same reasons and purpose. Consequently, in today's population-centric counterinsurgency approach, it should be possible, if exceedingly difficult, to appeal to that majority of the people who will fight only when compelled by circumstances or fear. In short, if it is possible to provide security at the local level, the hard core of insurgents will be starved of support, supply, and reinforcements. House draws on the Vietnam War as an example of the attempt to create positive outcomes through the closer 
integration of civilian nation-building, counterterrorism, and military efforts from 1967 forward. House concludes that interpreting the past helps us come to a better understanding of the present - and to better anticipate the threats and demands of the near future-but it cannot offer firm solutions. We can safely assume that insurgencies and asymmetrical warfare will be with us for some time to come, but local circumstances do not conform to rigid doctrine. The quintessential problem remains: the insurgent wins if he doesn't lose; the counterinsurgent has to win decisively so as to avoid a long, grinding, frustrating path to defeat.

James Carter reveals the close integration of the military-industrial complex of the Cold War era and private contractors in contemporary US foreign policy and in military interventions. He traces the roots of that pattern back to the Vietnam War, when private corporations were tasked with building the infrastructure and much of the logistics that permitted large-scale warfare in an underdeveloped country. While they contributed to the waging of war, contractors also played a critical role in the nation-building efforts. Carter's essay suggests that this dichotomy persists in the wars of our time. Indeed, he shows how the relationship between the military and defense contractors has grown ever more intimate since the 1960s, and he points at the fundamental problems of control and accountability of contractors, who do not have to abide by the same rules as the armed forces. Instead of suffering from a drawdown after the Cold War, contractors gained a greater role in the increasingly ambitious strategy of the United States, wherein fewer soldiers, sailors, airmen, and marines were asked to project power around the world. Contractors filled critical functions not only in the areas of arms manufacture and logistics, but also in what the public still generally regards as core military missions. To illustrate the continuities since the Vietnam War, and to show the growth of the military-industrial-contractor nexus, Carter considers in particular the role played by dozens of corporations in security and nation-building efforts in Iraq after the 2003 invasion. As he points out, more than $\$ 50$ billion worth of contracts were awarded to some 150 private firms for work in Iraq and Afghanistan in 2003 alone. The persistent influence of contractors, and the continuing phenomenon of war profiteering, raises serious questions about how we conceive of the roles of the state and its armed forces and of capitalist ventures in war. Carter's contribution strongly suggests that there is little novelty in how the United States pursues the "new wars" of the twenty-first century. Aren't we still trying to solve the question of how to win in Vietnam?

Vanda Felbab-Brown argues that while it makes good sense to consider the wars of the late twentieth and early twenty-first centuries through the lens of asymmetric warfare, this phenomenon has manifested itself in quite different 
ways, and even the assumption that we won't see interstate wars in the near future appears difficult to support. Consequently, policymakers and military commanders alike need to weigh the lessons of the past very carefully in order not to fall prey to rigid misreading of the present. Felbab-Brown reminds us that religion and ideology have served as motivating factors for challengers of the established order, but she cautions that a historically determinist view of quasi-religious wars between civilizations does not capture reality. New technologies, particularly in the field of communications, and the vulnerability of cyberspace introduce further complexity to international security and to the stability of the nation-state. The upshot of Felbab-Brown's erudite discussion is the increasing spectrum of war and violence and the resulting concern that conventional military force and counterinsurgency capability cannot address the whole range. This is particularly apparent in the responses of Mexico, Colombia, Jamaica, and other countries to crime, a de facto insurgency by drug cartels, and escalating gang violence. In those cases, the state has been on the defensive in efforts to rein in illicit economies, which have done great harm to national prosperity, and in providing basic security for its citizens. FelbabBrown concludes that the intertwining of crime, terrorism, and insurgency is dependent on local conditions and that historical and contemporary examples suggest the need for muscular peacekeeping on the ground and for careful intelligence gathering rather than for reliance on airpower and offshore strikes to topple an odious regime. Decisions on the nature of peacekeeping have to be made in advance of military intervention, so that the occupying forces can utilize the initial readiness of local population to cooperate against those who would thrive from instability and fear. Felbab-Brown ultimately reminds us that long-term stability requires both local consent and international engagement, and she suggests that intervention in local crises needs to be complemented by rigorous actions against the most rapacious transnational networks and crime syndicates.

In part 3, Robert Rotberg and Ken Menkhaus suggest two rather different systemic responses to state failure.

In "Odious and Failed States, Humanitarian Responses," Robert Rotberg advances the forceful argument that the world's great powers and international institutions have a responsibility to intervene in failing states on humanitarian grounds. His definition of what constitutes state failure is shaped by a belief in the universal appeal of democracy and human rights, and he suggests that states that attack and abuse their own citizens and subjects are highly likely to suffer from irreparable social stress and economic decline. Rotberg labels the most repressive regimes "odious," and he suggests that they are bound to collapse, which further increases the vulnerability of their already oppressed 
and abused people. He is concerned with two fundamental issues: Should the world community intervene before an odious state collapses and perhaps fragments? And, can we agree on a responsibility-to-protect doctrine? Rotberg considers regimes that one may call the usual suspects, North Korea, Burma, and Zimbabwe prominently among them; and he discusses the upheaval in North Africa and the Middle East as the most recent-and in some cases still ongoing - example of the domestic and international ramifications of the slide of odious regimes into failed states. He argues that the international community should act against those that place themselves outside the modern human rights regime. In a conflict between sovereignty and justice, he suggests, the global community should emphasize the latter. Doing so will strengthen the humanitarian foundation of the modern world and help ensure stability in a fragile world order.

Ken Menkhaus offers a reflective essay on the local response to state failure in Somalia that proposes an important corrective to the generally deeply pessimistic assumptions of what happens when a state collapses. Apocalyptic visions of outsiders and hyperbole of casual observers notwithstanding, the lack of central governance and the breakdown of what we consider to be the fundamental functions of the modern state-security and law and orderhave not led to outright anarchy in all parts of the country. Instead, Menkhaus shows that there are alternative sources for at least a degree of stability based on customary law, communal voluntarism, and creative ways to establish security and allow local economies to grow. But if local communities may provide "governance without government," in Menkhaus's words, could they also serve as the nucleus for new state structures? That is, could there be an organic response to state failure that would allow for measured engagement rather than outside intervention? Yet his discussion of the emergence of a radical Islamist regime also suggests that any local recovery remains fragile, and informal governance may require protection by military force.

The themes and policy dilemmas raised in this volume underscore that the global community cannot effectively create or maintain absolute security for all. On the other hand, our instinctive response to the images of murder, rapine behavior of militias or soldiers, and a steady flow of refugees that have accompanied wars and violent conflicts in the past decades equally suggests that we cannot idly stand by. And yet we have to come to terms with the complex reality that has characterized recent wars around the globe and that has made it very difficult to know exactly when and how to intervene. The still-ongoing civil war in Syria offers a case in point. The most striking commonality in these essays appears to be an appeal for education and careful analysis, based equally on forecasting models and on cultural and historical awareness. Most 
importantly, we can draw the conclusion that great powers and nongovernmental actors within the global community have to integrate local, regional, and even global responses into a coherent strategy that would allow for success in the "wars" on drugs, terror, poverty, and crime. If prosperity is indeed the main indicator for peace and stability, then the best responses to state failure and resulting or concurrent upheavals can neither stop at installing a new political regime nor be confined within national borders.

\section{NOTES}

1. See, for instance, Christopher Bayly and Tim Harper, Forgotten Wars: Freedom and Revolution in Southeast Asia (Cambridge, MA: Harvard University Press, 2006); and Ronald H. Spector, In the Ruins of Empire: The Japanese Surrender and the Battle for Postwar Asia (New York: Random House, 2007).

2. Herfried Münkler, The New Wars, trans. Patrick Camiller (Cambridge, MA: Polity Press, 2005); Mary Kaldor, New and Old Wars: Organized Violence in a Global Era, 2nd ed. (Stanford, CA: Stanford University Press, 2007).

3. See, for instance, Geoffrey Parker, The Military Revolution: Military Innovation and the Rise of the West, 1500-1800, 2nd ed. (Cambridge: Cambridge University Press, 1996). Charles Tilly's quote is from Tilly, "Reflections on the History of European State-Making," in The Formation of National States in Western Europe, ed. Charles Tilly (Princeton, NJ: Princeton University Press, 1975), 42.

4. Christopher Capozzola, Uncle Sam Wants You: World War I and the Making of the Modern American Citizen (New York: Oxford University Press, 2008).

5. James J. Sheehan, Where Have All the Soldiers Gone? The Transformation of Modern Europe (Boston: Houghton Mifflin, 2008).

6. For the long-standing tradition of humanitarian intervention, see Gary J. Bass, Freedom's Battle: The Origins of Humanitarian Intervention (New York: Knopf, 2008). For the American nation- and state-building creed, see Tony Smith, America's Mission: The United States and the Worldwide Struggle for Democracy (Princeton, NJ: Princeton University Press, 2012); and Robert Kagan, The World America Made (New York: Knopf, 2012).

7. Azar Gat, War in Human Civilization (Oxford: Oxford University Press, 2006), 618-61.

8. David Brooks, "Sam Spade at Starbucks," New York Times, April 14, 2012, http://www.nytimes.com/2012/04/13/opinion/brooks-sam-spade-at-starbucks. html?_r=1\&src=tp\&smid=fb-share.

9. Anthony Zinni, "Failed States: Keynote Address at the 2011 Baker Peace Conference" (Ohio University, Athens, April 7, 2011).

10. Odd Arne Westad, The Global Cold War: Third World Interventions and the Making of Our Times (Cambridge: Cambridge University Press, 2005). 


\section{REFERENCES}

Bass, Gary J. Freedom's Battle: The Origins of Humanitarian Intervention. New York: Knopf, 2008.

Bayly, Christopher, and Tim Harper. Forgotten Wars: Freedom and Revolution in Southeast Asia. Cambridge, MA: Harvard University Press, 2006.

Brooks, David. "Sam Spade at Starbucks." New York Times, April 12, 2012. http:// www.nytimes.com/2012/04/13/opinion/brooks-sam-spade-at-starbucks. html?_r=1\&src=tp\&smid=fb-share.

Capozzola, Christopher. Uncle Sam Wants You: World War I and the Making of the Modern American Citizen. New York: Oxford University Press, 2008.

Gat, Azar. War in Human Civilization. Oxford: Oxford University Press, 2006.

Kagan, Robert. The World America Made. New York: Knopf, 2012.

Kaldor, Mary. New and Old Wars: Organized Violence in a Global Era. 2nd ed. Stanford, CA: Stanford University Press, 2007.

Münkler, Herfried. The New Wars. Translated by Patrick Camiller. Cambridge, MA: Polity Press, 2005.

Parker, Geoffrey. The Military Revolution: Military Innovation and the Rise of the West, 1500-1800. 2nd ed. Cambridge: Cambridge University Press, 1996.

Sheehan, James J. Where Have All the Soldiers Gone? The Transformation of Modern Europe. Boston: Houghton Mifflin, 2008.

Smith, Tony. Americas Mission: The United States and the Worldwide Struggle for Democracy. Princeton, NJ: Princeton University Press, 2012.

Spector, Ronald H. In the Ruins of Empire: The Japanese Surrender and the Battle for Postwar Asia. New York: Random House, 2007.

Tilly, Charles. "Reflections on the History of European State-Making." In The Formation of National States in Western Europe, edited by Charles Tilly, 3-83. Princeton, NJ: Princeton University Press, 1975.

Westad, Odd Arne. The Global Cold War: Third World Interventions and the Making of Our Times. Cambridge: Cambridge University Press, 2005.

Zinni, Anthony. "Failed States: Keynote Address at the 2011 Baker Peace Conference." Ohio University, Athens, April 7, 2011. 

PART I

State Failure? 



\section{CHAPTER 1}

\section{The Future of War \\ Understanding Fragile States and What to Do about Them}

\section{David Carment and Yiagadeesen Samy}

\section{INTRODUCTION}

"Fragility" is not a term typically applied to countries as dissimilar as Haiti, Pakistan, and Yemen. Yet each is fragile in its own unique way. Yemen ranks poorly using legitimacy standards, which include measures of gender equity, political representation, human rights, and rule of law, among others. Pakistan is a poor performer in political and social development and is plagued by low-intensity turmoil, political instability, and other internal challenges to its authority structures. A more typical choice for a high-ranking fragile state would be Haiti, and, indeed, this is a country that suffers from weaknesses in multiple areas of political and social performance but is especially weak in economic capacity. Depending on the specific point in time at which one examines each of these states, they could also be described as "weak," "failing," or "failed" states (see fig. 1 on page 4).

In comparing these three examples, we can see that some states more easily fit our understanding of what we think a fragile state should be. These are states that have typically fallen into complete collapse brought on by "manmade" calamity, such as civil war or a mismanaged economy, sometimes exacerbated by environmental degradation or natural disasters. These states are, despite international efforts, utterly incapable of managing their political and economic space. 


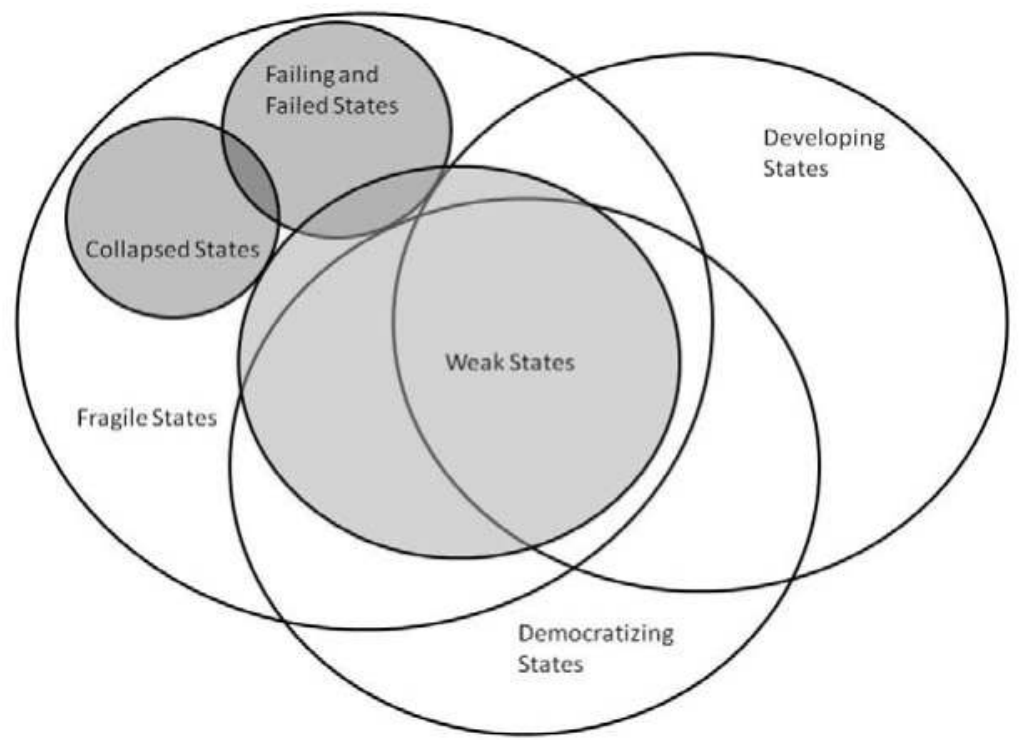

Figure r: Fragile States Venn Diagram

State fragility can also be understood as a composite measure of all aspects of state performance, resulting in those countries that are typically "failed" being ranked at the top of the list. This list would be recognized by most policymakers and academics; indeed, if one surveys the vast literature on fragility and the various rankings available, it is clear that such lists do not vary that much in terms of which countries appear at the top. There are thirty to fifty so-called "fragile" states, most of which are experiencing or have experienced large-scale violence and suffer from internal challenges to their authority structures.

State fragility is also an unfolding and ultimately indeterminate process associated with a subset of performance standards. More generally, the economic capacity problems that beset the fragile states of sub-Saharan Africa are distinct from the legitimacy and authority problems of the fragile states of the Middle East and South Asia.

The definition of "fragility" that we use in our research called the Country Indicators for Foreign Policy (CIFP) project (www.carleton.ca/cifp) rests upon conceptualizations and measures that are relative. Some states may be strong by certain measures and weak by others. The proper referents for understanding state fragility include not only a state's own past, present, and future performance in absolute terms, but also its performance relative to other states 
at any given point. The rate of change, which is understood by examining a state's relative performance, whether progressive or regressive, tells us whether a state is moving toward increasing fragility or whether its situation is improving. In other words, structural characteristics and measures of performance are useful for understanding state fragility only if there are appropriate reference cases with which to compare. And since these reference points are themselves evolving over time, it is important to understand that "fragility" is a relative term and has meaning only with respect to state performance at specific points in comparison with a given state's peers. Figure 1 identifies how fragility fits into our understanding of related concepts. We can see that fragility encompasses more specific concepts such as failed, collapsed, and weak states and overlaps with but is not equivalent to developing and democratizing states.

In brief, fragility is not an "end state" such as failure or collapse; properly understood, it is a convergence of structural changes and processes that arise under specific conditions that are evolving over time. Fragility is a measure of the extent to which the actual practices and capacities of states differ from their idealized image. It is a matter of degree, not kind. It is intended to be a general term, one within which related, though more specific terms, including "weakness," "failure," and "collapse," may be located. Fragility is a measure of the extent to which the actual institutions, functions, and political processes of a state accord with the strong image of sovereign state, the one reified in both state theory and international law. By this definition, all states are to some extent fragile; this is a closer representation of reality than an arbitrary line, however drawn, between weak and strong or resilient and vulnerable.

Obviously, some countries have sufficiently robust capabilities across all vital dimensions of stateness such that we would not apply the adjective "fragile" to them, even as some states are so challenged across various measures that few observers would argue that they are anything but fragile. To put it bluntly, no one will disagree that the failed state of Somalia is extremely weak and dysfunctional across several structural characteristics.

The three core structural parameters for understanding fragility are authority, legitimacy, and capacity (represented by the acronym ALC). First, there is the development or economic capacity problem. Populations living in fragile states are further from achieving the Millennium Development Goals (MDGs) than any others on the planet. Among all developing nations, though they comprise roughly one-sixth of the world population, fragile states by various definitions account for a disproportionate amount of the absolute poor, of children who do not receive a primary education, of children who die before their fifth birthdays, of maternal deaths, of people living with HIV/ AIDS, and of people lacking safe drinking water. 
"Capacity" refers to the potential for a state to mobilize and employ resources toward productive ends. Its actual ability to do so is captured through our measures of authority and legitimacy. States lacking in capacity may prove unable to respond effectively to sudden shocks such as natural disasters, epidemics, food shortages, or refugee flows. They may not have sufficient resources to feed, clothe, and educate their population, particularly in the presence of exogenous shocks of all kinds, whether domestic or international, whether natural or human in origin. They may therefore be heavily reliant upon civil society and the international community in such situations. Key measures of capacity include gross domestic product (GDP) per capita, education, human development, infant and maternal mortality, literacy, disaster risk, arable land, and energy consumption (from a total basket of about twenty indicators).

Second, there is the authority problem, namely, the inability to control both people and territory. Since the end of the Cold War, fragile states have overwhelmingly been the locus of much of the world's violence, both conflictrelated and otherwise. Today, however, politically motivated civil conflict is not the only source of violence and instability in fragile states; fear of criminal and drug-related violence has come to dominate these states and their neighbors, surpassing concerns regarding terrorism, civil war, and international conflict. A state that does not fulfill the most basic obligations of authority is a state whose leadership does not have the means and credibility to compel internal order or to deter or repel external aggression. In addition, that leadership does not, or cannot, provide sufficiently for the people to attract minimal sufficient domestic support. Fragility begins when the central state starts to deteriorate, leading to the fractionalization of society, with loyalties shifting from the state to traditional communities that seem to offer better protection.

The parameter of "authority" captures the extent to which a state possesses the abilities to enact binding legislation over a population, to exercise coercive force over its sovereign territory, to provide core public goods, and to provide a stable and secure environment to its citizens and communities. States lacking in authority may be unable to exercise control over the full extent of their legal territory; such states will likely have difficulty responding effectively to threats, whether internal or external. In some areas, nonstate actors such as rebel militias or criminal organizations may possess de facto authority; in others, the rule of law may be completely absent. Border control may be intermittent or nonexistent, enabling illicit flows of people and goods. Essential government services may be either underprovided or privatized. Other potential problems include the inability to enforce government policy, combat corruption and criminality, effectively mobilize the resources of the state toward the ends requested and required by government, regulate private markets, or guarantee contracts. 
Key measures include: rule of law, economic growth, internal rebellion, border disputes, size of the informal economy, paying taxes, military expenditures, political stability, terrorism, refugees hosted, and regulatory quality (from a basket of about twenty-five total indicators).

Finally, there is the legitimacy problem. When it comes to practicing effective governance, many fragile states lack the legitimacy to be effective and responsive policymakers. To be sure, while there are still some deeply entrenched and often predatory regimes among those states we call fragile, many simply reflect a disengaged population weary of governments incapable of providing basic services and a legal system that makes contractual relationships, property rights, and respect for human rights untenable. Fragile states need an institutional architecture for consolidated and sustainable political competition that ensures elites are answerable to the people they serve.

The emergence of state disorder is due to the failure of prevailing societal values to legitimize existing divisions of labor and political order. Perceptions and expectations are essential determinants of how a society views and reacts to state policy. In some cases, fragile states are in transitional stages in which existing ideologies fail to legitimize the positions of various actors in a hierarchical social structure. Under such conditions, the result can be the breakdown of the social and political orders. In the context of state fragility, the destruction of national identities stands in the way of acquiring shared values that could provide a basis for intergroup cooperation and recognition of a common authority. The obstacles to contractual or hierarchical solutions to the problem of mutual noncooperation are analogous: both the trust required for a contract and the legitimacy needed for stable authoritative hierarchy will be elusive when state-society relations are weak.

The legitimacy parameter refers to the extent to which a state commands public loyalty to the governing regime, and the extent to which domestic support is generated for that government's legislation and policy. Such support must be created through a voluntary and reciprocal arrangement of effective governance and citizenship founded upon broadly accepted principles of government selection and succession that is recognized both locally and internationally. States in which the ruling regime lacks either broad and voluntary domestic support or general international recognition suffer a lack of legitimacy. Such states face significant difficulties in maintaining peaceful relations among various communities within the state; any security found within the state is likely the result of coercion rather than popular consent. As a result, such states are inherently vulnerable to internal upheaval, and must be considered fragile as a result. Key measures of legitimacy include gender equality, level of democracy, minority rights, civil and political rights, freedom of the 
press, corruption and transparency and accountability, and international covenants on human rights (from a basket of about fifteen total indicators). ${ }^{1}$

\section{PROFILES OF FRAGILITY}

Let us return now to the three examples cited at the beginning of this paper. Our motivation for choosing these cases is that they are almost always listed among the most fragile states when one examines the various annual rankings produced by different organizations, including CIFP. Yet a closer examination of the underlying factors leading to fragility in these states (see below) indicates that they are also each unique in their own way. In this section, we will thus identify the various risk factors that contribute to making these three states fragile, highlight some trends regarding their changes over time, and identify some policy options for external actors. We will then conclude with some general recommendations for policymakers. In an effort to illustrate the tripartite approach discussed above, each profile highlights particular areas of state weakness: Pakistan's authority challenges, Haiti's capacity challenges, and Yemen's legitimacy challenges. To be sure, each of these countries has weaknesses in all three areas, but, again, it is notable that these countries are distinct in the way their fragility is manifested.

\section{PAKISTAN: THE PIVOTAL STATE}

In January 2008, following the assassination of Benazir Bhutto, an Economist editorial argued that democracy offered the best chance for bringing stability to what the magazine called "the world's most dangerous place." Pakistan's intricate relationship with Afghanistan makes it particularly important as a pivotal state in the War on Terror. To be sure, both Afghanistan and Pakistan have taken divergent paths in nation-building. For example, whereas Afghanistan is a true client state, Pakistan tends toward the bureaucratic authoritarian, with a largely untaxed middle class that benefits from a lax financial system, and a strong military apparatus that has proved the most incapable of delivering emergency services. Although governance is a primary area of weakness throughout the region, particularly with regard to inclusiveness, transparency, and accountability, security concerns, both domestic and regional, undermine attempts to strengthen Pakistan's internal governance structures. The grievances of many of the groups engaged in violent conflict in Pakistan stem largely from frustrations with its system of governance.

Pakistan belongs to a group of second-tier countries, which, though not being outright failures, are particularly vulnerable in certain aspects of "state- 
ness." CIFP's rankings have placed Pakistan in the top twenty fragile states in the world in most years during the past two decades. On the one hand, as Pakistan's inability to control internal conflict, environmental degradation, and a highly unequal society increases over time, the legitimacy of the government continues to erode and challenges from within increase. Indeed, historically, aid to Pakistan has been used to shore up a centralized authority structure, whether it was perceived to be legitimate or not. That reinforced authority structure, a kind of bureaucratic authoritarianism, has been in place since the 1950 s.

On the other hand, the risks that Pakistan poses to its neighbors have been shaped by its historical rivalry with India. Pakistan's behavior, specifically in reference to Kashmir, was, until it acquired its own nuclear weapons, formed by the need to counterbalance Indian military superiority. Beyond Kashmir, the news does not get any better. In addition to supporting separatist movements and terrorist attacks in India, Pakistan has provided sanctuary and training, as well as arms, to other hotbeds of conflict throughout Asia, including Sri Lanka, southern Thailand, and of course to the mujahideen in Afghanistan during the war against Russian occupation.

More fundamental analyses suggest that the risks Pakistan poses lie in the need to externalize internal tensions through territorial expansion and conquest — what MIT professor Myron Weiner called many years ago the "Macedonian Syndrome." ${ }^{2}$ This argument is based on the assumption that the only way to hold together an ethnically fractionalized and artificial country like Pakistan is through strong-arm leadership. The key attributes are a highly centralized government, heavy investment in the military security apparatus, and a very weak middle class.

In essence Pakistan's problems are to a large extent self-created. An analysis of the country's underlying risk shows that it faces significant performance challenges in all but a few of its core state functions. Of particular concern are its governance and human development scores, low even when compared to others in the region. It is both weak and unstable and ranks as the third-mostfragile state in Asia. It is particularly weak in authority-ranked fourth in Asia by our measurements because of security challenges presented by various armed militant groups, and this despite receiving massive military aid from the United States since the 9/11 attacks. Further, the government has been unable to extend control throughout the country, and faces secessionist movements from tribal and militant groups. State legitimacy is also problematic, as attempts to retain control of the government and army draw protests from numerous quarters. The country has had an average of more than one hundred bombings a year during the last several years. 
To be sure, Pakistan's capacity is also a high-risk area. The capacity of the state to respond to the needs of the population is weak. Although growth rates in per capita terms have been mostly positive since the 1990s, at an average of nearly 2 percent, poverty remains a growing problem. According to the latest Human Development Report, 60 percent of Pakistan's population lives on less than $\$ 2$ a day, and 23 percent on less than $\$ 1.25$ a day. The country is ranked in the medium human development category, only a few ranks above countries such as Angola, Madagascar, and Haiti. It faces a range of development challenges in the areas of education, health, and respect for human rights, despite receiving more than US $\$ 44$ billion in foreign aid since 1960 (our calculations using World Bank data). Pakistan will most likely not meet its MDGs in primary education and gender equality, nor in child and maternal mortality.

Less than 2 percent of Pakistan's population pays income tax-the result of loopholes in the system, corruption, and the protection of special interests among others-so that the country's revenue from taxes is one of the lowest in the world. The absence of an efficient tax system means that the wealthy are largely untaxed, thus preventing any meaningful redistribution of income or creation of a fiscal pact where government has to be accountable to its taxpayers. Why tax and be accountable when aid, despite being volatile, keeps flowing in year after year?

In addition, there are a number of militant groups in Pakistan, varying in size and strength from small tribal groups to national militant organizations. There are many pro-Taliban militant groups situated in North and South Waziristan and the North-West Frontier Province. These groups occasionally cooperate but are often engaged in low-intensity violent conflicts with other militant groups.

With respect to sequencing, we can see that after Pakistan experienced internal violence over the last couple of years, there was an effort to shore up existing authority structures, no matter how weak they were, as a bulwark against further decline. Such an emphasis, exemplified in the United States' long-term-aid program for Pakistan (as a result of its support for allies in the Global War on Terror), led to a distortion in both the selection of aid recipients in Pakistan and the type of aid provided. A large amount of aid has been given to Pakistan, a state with limited authority and capacity, regardless of the legitimacy of the regime in power. The result is a deeply unpopular, nearly illegitimate regime, heavily dependent on external aid that can be unstable over the long term. This "shoring up" of authority structures then results in a vicious cycle of further decline, where both capacity and legitimacy are undermined and in turn authority is further challenged (see fig. 2 on page 11 ). 


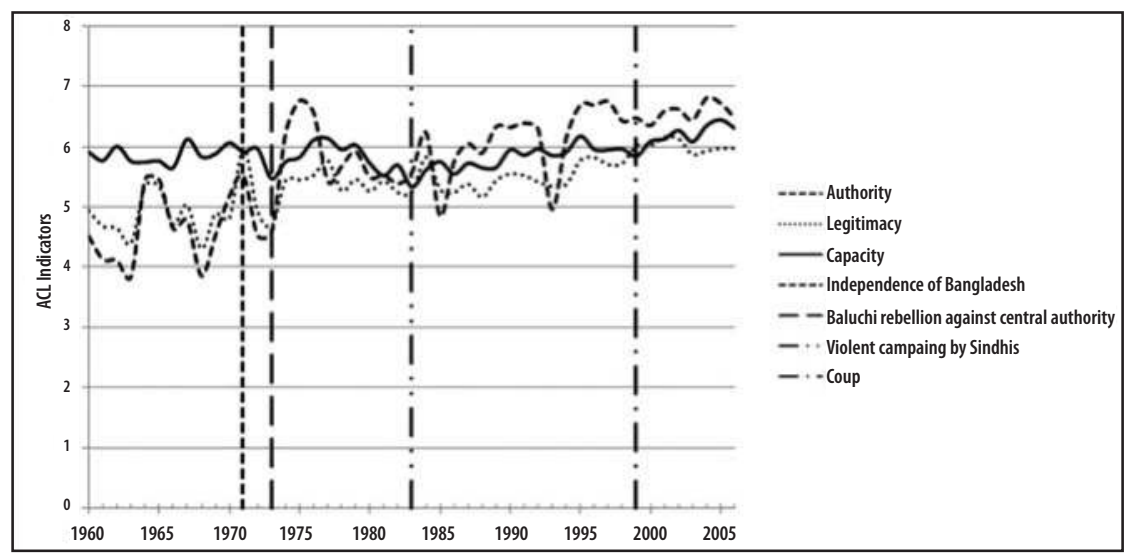

Figure 2: ALC Indicators for Pakistan

The negative reinforcement of Pakistan's authority structures is achieved through an institutional system, political structure, and popular media in Pakistan that collectively reinforce the identity of statecentric nationalism. The Pakistani state is not so much a subordinate to dominant ethnic groups but rather works in partnership with them. This partnership is reinforced when the state is challenged by regional minority groups, itself a response generated by assimilative pressures, policies on in-migration, economic competition, and, more recently, political threats of secession.

The net result is a lethal "policy feedback" process, in which the central government's policies in Karachi, in the form of entitlements for the majority ethnic groups, induce minority groups to organize for political action. This challenge in turn generates greater resistance to change from the state-center. Simply put, the sequencing of Pakistan's increasing fragility appears to begin with a deterioration in its authority structures, which, rather than being adaptively modified in a positive way, are negatively reinforced, with the consequence of increasing instability over the short run.

Is democracy a viable alternative for bringing stability to Pakistan? Though the country has flirted with democracy since independence, there is little reason to believe it will be a panacea. An opening up through democratization would create opportunities for increased challenges from within and the possibility that fundamentalists might win elections. 
No country is in a position to "fix" Pakistan. Changes must come from within. But there are good reasons for hastening and widening the integrated regional approach to stability called the "Dubai process." Such an approach requires a frank assessment of how Pakistan and Afghanistan (and India) are historically interlinked, how Pakistan has historically been the source of much of the instability in the region, and recognition that the current strategy on Pakistan is not working. Most importantly, it means understanding that Pakistan's internal problems are fundamentally linked to core problems in governance and human development.

If Pakistan fails, the costs will be immense. Research conducted by Lisa Chauvet, Paul Collier, and Anke Hoeffler has shown that ignoring fragile states can be extremely expensive in terms of development, as well as for neighboring countries and the international community. ${ }^{3}$ These authors estimate the annual cost of failing states to be more than twice the amount of aid being distributed globally, with most of the cost being inflicted on neighboring countries. It is far more expensive to invest in rebuilding failed states than to monitor and take appropriate preventive action in fragile environments. A strategy of reacting to events is clearly not sustainable in the long run. Pakistan is a good example of a situation where preventive strategies focused on promoting good governance and human development must be applied.

\section{HAITI: FRAGILITY AS VULNERABILITY}

Since its independence, Haiti has had a troubled economy. Even by historical standards, however, its recent experiences have been particularly traumatic. It is the only non-African country other than Afghanistan that is consistently ranked among the top ten most fragile states. In fact, Haiti has failed to achieve any real growth and development over the last several decades. Its GDP per capita in 2008 of US $\$ 1,087$ was roughly half of what it was in 1980 , and life expectancy at birth is at sixty-one years; the corresponding numbers for its immediate neighbor, the Dominican Republic, are US\$7,600 and seventy-two years. Haiti received US $\$ 8.9$ billion in foreign aid over the period of 1960 to 2008, yet it is ranked 149th out of 182 countries on the latest human development index (HDI), with 72 percent of its population living on less than $\$ 2$ a day and 42 percent not using an improved water source. ${ }^{4}$ In addition to Haiti's many poverty-driven problems, there are also issues related to the extreme inequality that exists in the country. Haiti has an extremely small, mostly French-speaking elite that dominates much of the country's assets; most measurements of income inequality place Haiti at or near the bottom of the list of developing countries. 
The difficulties that Haiti faced in the immediate aftermath of the 2010 earthquake in terms of rescue efforts and aid coordination on the ground stemmed from deep underlying weaknesses in governance, human development, economic development, and security that were in place many decades before the earthquake struck. Poverty and fragility meant that security was never guaranteed, that property rights had been virtually nonexistent, that there were no building codes, that construction-quality standards were not respected, and that successive governments were too weak to enforce whatever standard was in place. For most of its contemporary history, Haiti's governments and leaders have failed to provide security to their people, to promote economic freedom, or to encourage entrepreneurship. The result is an extremely weak formal economy with entrenched corruption that is heavily dependent on external assistance, and a large informal sector where most people are barely surviving.

Much of the extreme degradation of Haiti's environment, particularly its level of deforestation, can be explained by demographic factors; the deforestation is also a direct result of the levels of poverty in the country. For decades, rural Haitians have been forced to turn to local forests as a source for cooking fuel in the absence of reliable and affordable alternatives. In 2000, the island nation had 880 square kilometers of forest, covering just 3.2 percent of the total land area. The remaining forest was disappearing at a rate exceeding 5 percent per year. ${ }^{5}$ Without significant tree cover, the land cannot absorb even moderate levels of rainfall. Thus, whereas other nations may not be unduly disturbed by a given storm, Haiti is likely to be deeply affected. When intense phenomena such as tropical storms hit the country, the results are inevitably tragic.

Haiti also suffers from a range of macroeconomic problems, including an extreme and chronic lack of liquidity. Its levels of foreign direct investment and foreign aid improved somewhat in the latter half of the 1990s but collapsed again in the wake of Jean-Bertrand Aristide's 2000 reelection and the resulting American decision to suspend all bilateral aid. Aid flows have been on the rise again in the past few years. Haiti's industry has gradually decayed since the early 1990s and was only recently slightly revived through the Hemispheric Opportunity through Partnership Encouragement (HOPE) Act. Haiti's other traditional exports are largely agricultural, including cash crops such as sugarcane, coffee, and mangoes. These continue to suffer due to international agricultural tariffs, as well as increased competition from new market players such as Vietnam. There are few other sources of economic growth within the country; as a result, Haitians have had to increasingly turn to other sources of income, including international remittances and, in more extreme cases, illicit activities such as corruption, kidnapping, and drug trafficking. Transparency 
International ranked Haiti 168th out of 180 countries in its 2009 corruption perceptions index, which measures the perceived level of public-sector corruption. Criminal activities are becoming increasingly transnational in character; the activities of Haitian organized-crime gangs are becoming a matter of increasing importance for Canada. ${ }^{6}$

Despite seeing a large part of its debt written off as a result of reaching the completion point of the Heavily Indebted Poor Countries (HIPC) Initiative, Haiti still owed US $\$ 1.25$ billion in 2009 (according to IMF data). Of this amount, the biggest creditors were the Inter-American Development Bank (34 percent) and Venezuela's Petrocaribe (24 percent). ${ }^{7}$ However, following the earthquake, President Hugo Chávez announced that Venezuela would cancel Haiti's debt. Given Haiti's poor track record, one has to wonder what all those loans and remittances have accomplished.

Corruption and lack of independence within the judicial system also contribute to the instability of the political system, further weakening government checks and balances. With no independent body able to review government actions, Haitians have little choice but to hope that the elected president remains committed to democracy and broad-based economic growth. Although Haiti features a relatively rural population by regional standards, the capital of Port-au-Prince tends to dominate political decision making within the country. As a result, many regions are excluded from efforts to enhance economic and social benefits; this increases discontent and reduces the legitimacy of the central government. Further, although the government of Haiti ostensibly controls all areas of the country, in reality many rural jurisdictions are in fact under the de facto control of local individuals or groups. In some cases, these groups use this control to dominate the local population.

In 2005, the entire Haitian diaspora sent US\$985 million home in the form of remittances, contributing the equivalent of one-fourth of Haiti's GDP. The diaspora helps alleviate poverty by sending money to friends and family, but also by providing them with goods for private consumption or retail. Although the Haitian population uses an important part of remittances sent to buy consumer goods, only a small percentage of the money is saved, invested, or spent on services with positive externalities such as education and basic health care. The question as to why there has been only a minimal impact on social capital in Haiti can be answered by considering that the Haitian national government has not encouraged senders and recipients of remittances to save and invest in supporting good governance because the country receives so much in aid to do precisely that. A functioning banking and legal system free of corruption and with lower transaction costs would also increase the benefits linked to remittances. For example, transfer costs and transaction fees 
are currently high and can amount to more than 5 percent of the money transferred in the form of remittances.

Despite immense remittance flows finding their way into households, the net impact of diaspora groups on the political process in Haiti has been somewhat ambiguous and counterproductive. That is because, in the case of Haiti, overly partisan political engagement by the diaspora group has encouraged more intransigent behavior by homeland politicians. This is true for most countries with a history of deep social divisions or open conflict, but exceptional in the case of Haiti. For example, beyond the political and economic activities that remittances might support, there is also the issue of crime financing in diaspora communities, and the potential for migrant groups to bring with them criminal patterns from their country of origin when they immigrate. Despite continuing debate regarding the true impact of criminal deportees on crime in Haiti, there are nonetheless firm reasons to suspect some connection. In essence, the practice by Canada and the United States of deporting convicted criminals to Haiti might be termed trade in human criminal capital. The potential exists for such criminals to use the skills and knowledge acquired in the host country to manipulate immigration systems, illegally reentering the country and acting as a criminal entrepreneur, thus facilitating activity between host and home countries, to the detriment of both. ${ }^{8}$

Haiti's performance has been appalling when compared to the global sample of countries. It was ranked among the top ten fragile states during the period 1983-1994, among the top twenty for most of the period of 1995-2003, and again among the top ten during the period of 2004-2007; its fragility score has deteriorated by 20 percent over the full period. The small gains that were made in rare periods of relative stability were quickly erased as a result of a combination of political instability, poor economic policies, and natural disasters. Let us examine figure 3 below, keeping in mind that just as in figure 2 , an increasing trend is associated with increasing fragility and deterioration in the ALC components. Capacity scores have always been very high (poor) in the case of Haiti and are also the least susceptible to rapid fluctuations. However, authority structures have worsened so much, followed by legitimacy, that they are now largely responsible for the fragility of the country. Except for capacity scores, there is a clear upward trend line in all other components.

In the case of Haiti, the situation was improving in the two years prior to the 2010 earthquake. In particular, improvements in authority structures and the political sphere were, to a certain extent, offsetting the country's poor economic performance. However, the earthquake's devastating effects have caused the situation in the country to deteriorate again. Specifically, we see increasing problems in governance, security and crime, human development, and the 


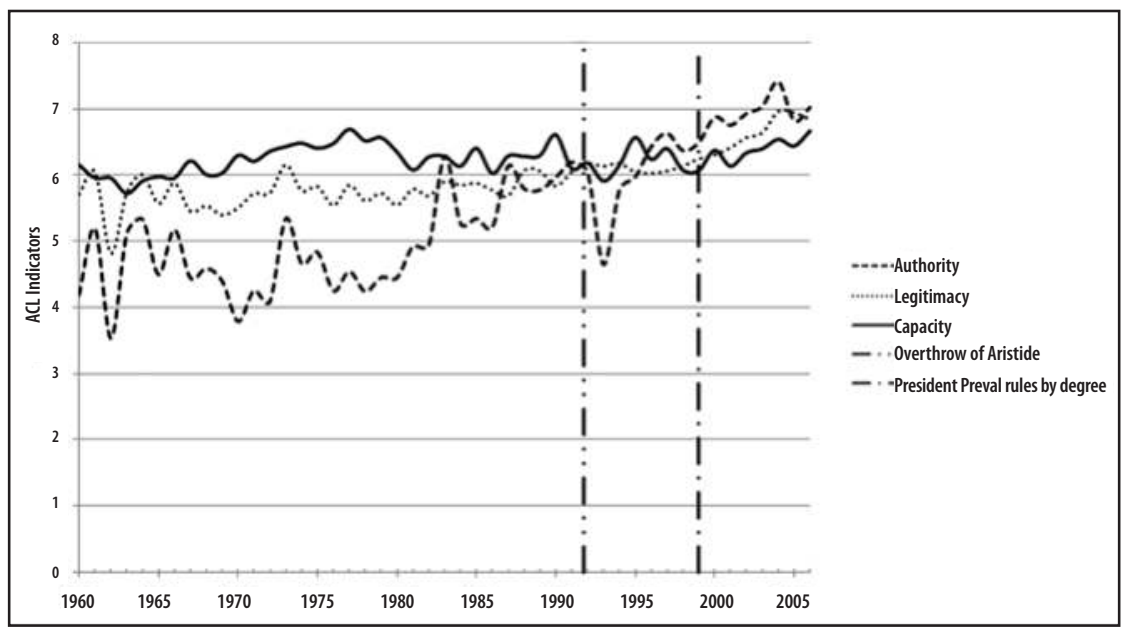

Figure 3: ALC Indicators for Haiti

environment, and only a very minor improvement in economic performance. A key goal in rebuilding the country should be increased capacity, focusing on economic development, and reinstating and creating basic services to its people. Second, providing security through proxy in order to reestablish effective authority and control over territories and people will be essential. Finally, only after authority and capacity have been stabilized should democracy be reintroduced to the country. After all, how is it that a leadership that was utterly incapable of providing for its people before and during the earthquake can be considered legitimate? It will take years if not decades to introduce less corrupt forms of leadership to Haiti. In summary, we have evidence of volatility and quick reversal in the case of Haiti, where rapid gains quickly evaporated as a result of an exogenous shock exacerbated by the lack of a functioning economy and a weak political system.

\section{YEMEN: TRIPLE THREAT}

In 2010, Yemen started to give way to internal stresses that had built up over the past decade. Not only is the Arab world's poorest nation challenged by mass protests of the kind that toppled tyrants in Egypt and Tunisia, brought civil war to Libya, and forced concessions from oil-rich despots in Bahrain and Saudi Arabia, it is home to a resurgent al-Qaeda, a northern Shiite uprising, and a revived southern secessionist movement. The 1990 North-South unification is proving to be untenable. The country could easily disintegrate into 
three or more pieces. Today, Yemen has replaced Afghanistan as the most important al-Qaeda stronghold in the world. Many of that organization's most dangerous operations have originated in Yemen. Judging from their recent actions, the extremists are both motivated and highly capable. ${ }^{9}$

Yemen's underlying sources of conflict and instability are impossible to solve over the short run. The country is running out of oil and water. Ali Abdullah Saleh, in power for more than thirty years, proved incapable of holding the country together without extreme force. Transitioning Yemen toward a more democratic system will only mean a hardening of tribal divisions and a deepening of the corruption, clientelism, and cronyism that are rife throughout the country.

Yemen's political authority, economic capacity, and regime legitimacy experienced modest improvements in the mid-1990s, but since 2000 have seen an alarming deterioration (see fig. 4 on page 19). Yemen's risk profile represents a country that has few positive economic, social, and political attributes. The country suffers from an underdeveloped and haphazard rule of law, uneven and inequitable economic development dividing the North and the South, an extremely corrupt civil service and judiciary, a weak educational system, poor service delivery, and a government struggling to control excessive spending on the military. Its leaders are heavily dependent on foreign aid to finance budget deficits and development programs. Yemen's taxation system, as in the case of Pakistan's and perhaps worse, is almost nonexistent, meaning the government is accountable to no one. Its agricultural sector is under threat due to water scarcity and a chronic inability to buy inputs such as fertilizer, putting at risk more than half of the country's economically active population who work in agriculture.

Even before the country transformed into a sanctuary for extremists, Yemen was one of the poorest in the world. It ranks 133rd out of 169 on the human development index, with a per capita GDP of about $\$ 1,000$ compared to an average of about $\$ 26,000$ for the other Gulf states. Yemen's GDP annual growth average of 2.6 percent is far below the regional average of 5.9 percent. Literacy and life expectancy are among the lowest in the world. There is a plethora of small arms scattered among Yemen's diverse tribal peoples, making security a major challenge. Adding to these problems, Yemen has a very high population growth rate of 3.46 percent and an extremely large "youth bulge" of 46.4 percent. ${ }^{10}$ More than 18 percent of its total labor force is unemployed, especially in urban areas. The urban population is growing at a rate double that of the total population, and city infrastructure is increasingly unable to handle that growth. Nearly half of Yemen's population lives below the poverty line with a daily income of $\$ 2$. Although many natural resources are located in 
the South, a reduced portion of public funds from an unsympathetic government leaves them hindered by grinding poverty. An analysis of Yemen's budget shows that the regime's priority has been military spending, an area dominated by Saleh's relatives. Military expenditures are typically four times the amount spent on health care.

Oil accounts for almost 90 percent of export earnings and around 70 percent of government revenue, making the country susceptible to internal shocks such as droughts and floods and external shocks such as oil prices. Based on current trends, oil reserves are expected to be depleted within fifteen years. ${ }^{11}$ Yemen is one of the most water-scarce regions in the world, with water tables falling by about two meters a year, a rate of extraction that exceeds precipitation by about 70 percent. Without corrective action, groundwater supplies in Yemen's capital, Sanaa, are expected to be exhausted very soon and already are unsafe to drink. Some fifty thousand Somalis flee to Yemen each year, leading to the diffusion of their conflicts. Outbreaks of violence within refugee camps are contributing to Yemen's instability.

The 1990 unification of the "republican" North Yemen with the formerly Marxist South Yemen was followed rapidly by civil war in 1994 . That conflict ensured the domination of Saleh's Northern forces and his tribe's control of the country's political institutions. Since then, Saleh has established an intricate network of patron-client relations in the North, while largely ignoring the economically weaker South. Saleh's government is heavily influenced by al-Qaeda Arabs, jihadists who fought for him in the 1994 civil war after their return from Afghanistan. Today, Bin Laden supporters are thought to be in positions of influence in the military and the government. Saleh also faces rebellion in the North from a band of very capable Shiite rebels in the Saada region on the border with Saudi Arabia.

There is some urgency to the situation for the people of both Yemen and the West. The country has become the center of al-Qaeda operations for attacks on the United States, including the 2000 bombing of the USS Cole in Aden, the failed targeting of CIA agents in 2010, and two attacks on the US Embassy in Sanaa in 2008. South Yemen-based al-Qaeda leader Anwar al-Awlaki, an engineer with US-Yemen dual citizenship, was implicated in the November 2009 Fort Hood shootings, the attempted bombing of a US aircraft in Detroit on Christmas Day 2009, and indirectly to the Times Square bombing attempt of 2010. Anwar al-Awlaki was killed in a drone attack on September 30, 2011, in Yemen.

In response, the Obama administration has made a more secure and stable Yemen an administrative priority, insisting that the country improve its efforts to track down al-Qaeda operatives in the South. The collusion between Saleh's 


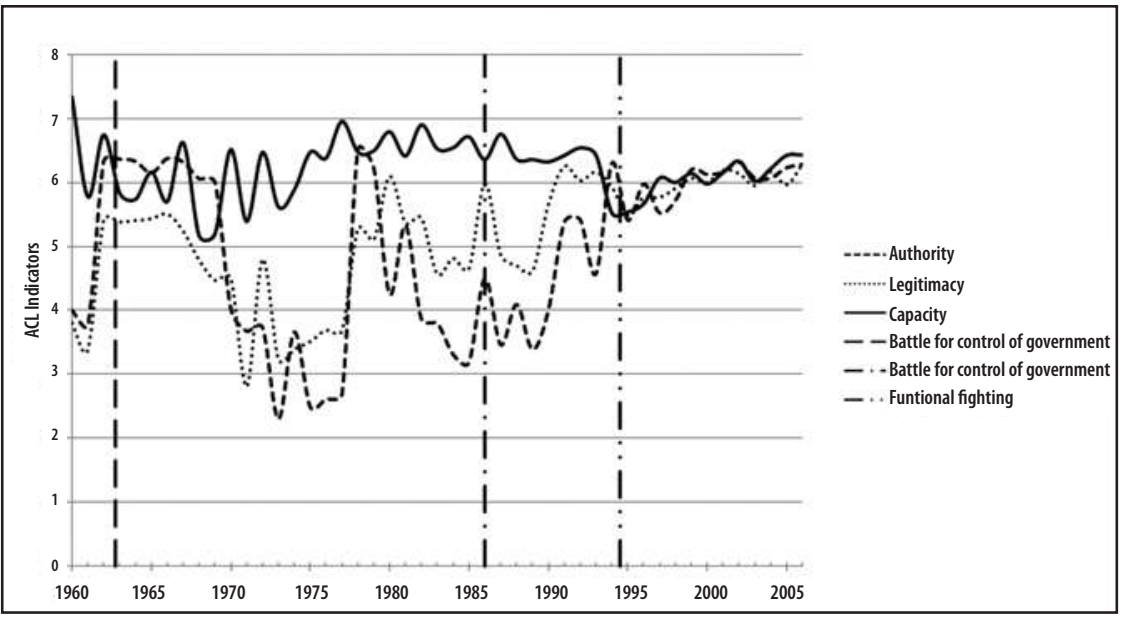

Figure 4: ALC Indicators for Yemen

military and al-Qaeda is seen as a major impediment to progress in that area, so, using a blueprint suggestive of the United States' approach to Afghanistan and Iraq, the administration is focusing on root causes. When she visited the country last year, Secretary of State Hillary Clinton announced that her government wanted a broader security relationship with Yemen beyond fighting extremists by tackling the sources of Yemen's fragility such as poverty and corruption. Between 2006 and 2010, US military assistance to Yemen has totaled about US\$250 million. In 2010, military and civilian aid was almost evenly split and combined for about US\$300 million and will increase in 2011.

If Yemen continues on its current trajectory, it will become a failed state in less than two years, and, depending on the actions of opposition forces and their supporters, collapse could come sooner. Yemen's implosion would have a significant impact on Saudi Arabia, itself feeling the direct effects of upheaval in the North. Failure would also give al-Qaeda unprecedented operational space in the South. For that reason the United States is reluctant to create a power vacuum by pressuring Saleh to step down (the US has not signaled that Saleh should resign as they did with Mubarak and Gadhafi). It has been suggested that giving the opposition greater opportunities in advance of the elections planned for 2013 might lead to an immediate reduction of tensions. Accommodation, democratization, and decentralization are often seen as solutions for moving a country away from authoritarianism. After all, 
democracy appears to be the path deemed suitable for some of Yemen's Arab neighbors. Yet there is little reason to believe democracy offers a way out for Yemen. Most of the country's major institutions are controlled by President Saleh and are largely dysfunctional. There remains a deep economic and political divide between the privileged North and the impoverished South. The gap between popular expectations and authoritarian rule looms so large in Yemen, it is doubtful that reform-minded movements like the kind we saw play out in Egypt, Tunisia, Bahrain, and Jordan could succeed without significant international involvement. The country is simply too poor and too divided and Saleh's tribe too powerful.

Looking forward, we can anticipate that Saleh will continue to collaborate with the United States for self-serving reasons: to maintain his control of power, to obtain access to foreign aid, and to use the cover of antiterrorism efforts to oppress opposition to his regime. The government's ongoing complicity with al-Qaeda is troubling, but it may also serve to co-opt some extremists. The problem is that the process of deradicalization may take years to succeed. The crux of the issue is that Yemen, like much of the Middle East, has an authoritarian leader clinging to control well past his due date, and there are no viable alternatives for keeping the country together.

Since the terrorist attacks in New York and Washington, DC, on September 11, 2001, which were facilitated through the support of al-Qaeda by the Taliban regime in Afghanistan, the world has realized that weak and failed states pose a threat not only to their own people but also to the security of other countries and the international community. In our extremely interconnected world, we can no longer allow countries to descend into chaos without expecting some of that to affect the rest of the world.

Yemen was the most fragile state in the Middle East and North Africa according to data from 2009-a year before the beginning of the Arab uprising that has since swept across the region. ${ }^{12}$ In fact, it is consistently ranked among the ten most fragile states in the world. Table 1 below shows how Yemen stacks up against the Middle East and North African countries (the MENA region is made up of twenty-one countries). Most have become politically or economically unstable for different reasons. Their social indicators such as life expectancy and primary school completion rates are not dire when compared, for example, to some of the countries in the sub-Saharan African region, yet protest and war are on the rise. The table shows that these protests and conflicts are related to legitimacy rather than to pure economic and political problems; the regional average for legitimacy is worse than the global average. Countries such as Saudi Arabia and Tunisia are to some extent fragile in their own unique ways. Yet both perform disappointingly in the basket of 
legitimacy standards, which include measures of gender equity, political representation, human rights, and rule of law.

\section{POLICY RECOMMENDATIONS}

Security, Development and the Fragile State: Bridging the Gap Between Theory and Policy ${ }^{13}$ emphasizes the multidimensional and multifaceted nature of the "fragile" state and highlights the need for continuous assessment and monitoring of countries at risk in order to be able to intervene before they begin to fail, and gives suggestions on how to transition them from fragility to sustainable and stable states when they begin to recover. The book also shows a disconcerting upward trend in fragility over time, despite increasing amounts of resources being devoted to fragile states. In particular, there is a widening gap between the most fragile and the most wealthy states.

Needless to say, there are numerous challenges to state-building that arise in the modern context, including risks of ethnic conflict, challenges to economic development, and regional instability. First, leaders must ensure that they have institutions to provide adequate services to the population. Second, they must find ways to properly channel ethnic, social, and ideological competition that will otherwise erode the effectiveness of weak institutions even more. Finally, leaders must find a way to overcome the cumulative effects of poverty, overpopulation, rural flight, and rapid urbanization, as well as environmental degradation, which can otherwise overwhelm a vulnerable state's legitimacy. Rebuilding fragile states is a function of the policies leaders choose. Narrow policies favoring one group are less sound than broad distributive ones. In severe cases, the state must ensure that on the one hand, it has the capacity to respond to crises produced by uneven ethnic mobilization and social change, and that on the other hand, it does not become the dominating force providing differential advantages to regions and ethnic groups.

Although state-building is primarily a domestic process that involves local actors, the role of international actors is still very important. The donor community can contribute to supporting and facilitating political and institutional processes in order to strengthen the basis for resilience through prevention, mediation, and support of underlying structures. This might include political settlements, working to underpin the responsiveness of the state to effectively fulfill its principal functions in providing key services, and supporting legitimate forms of societal political pressures that will determine how a state should function.

First, given the aforementioned conceptualization of fragility as being multidimensional, it follows that varying policy responses are required and need to be 


\begin{tabular}{|l|c|c|c|c|}
\hline Country & Fragility & Authority & Legitimacy & Capacity \\
\hline Yemen, Rep. & 6.7 & 7.2 & 7.4 & 6.1 \\
\hline Iraq & 6.5 & 7.5 & 7.0 & 5.5 \\
\hline Djibouti & 6.2 & 4.9 & 6.6 & 7.1 \\
\hline West Bank and Gaza & 5.9 & 6.7 & 6.9 & 5.3 \\
\hline Iran & 5.8 & 7.1 & 7.1 & 4.2 \\
\hline Algeria & 5.6 & 6.3 & 6.5 & 4.7 \\
\hline Lebanon & 5.4 & 5.5 & 6.0 & 5.1 \\
\hline Saudi Arabia & 5.4 & 4.7 & 7.4 & 5.1 \\
\hline Egypt & 5.3 & 5.4 & 6.7 & 4.6 \\
\hline Syria & 5.3 & 5.3 & 7.2 & 4.7 \\
\hline Jordan & 5.0 & 4.0 & 6.6 & 5.3 \\
\hline Libya & 5.0 & 4.6 & 7.4 & 4.3 \\
\hline Kuwait & 4.8 & 4.5 & 5.7 & 4.6 \\
\hline Morocco & 4.8 & 3.8 & 6.2 & 4.9 \\
\hline Bahrain & 4.6 & 3.9 & 6.3 & 4.5 \\
\hline Oman & 4.6 & 3.6 & 6.1 & 4.6 \\
\hline Qatar & 4.4 & 3.0 & 6.3 & 4.5 \\
\hline Tunisia & 4.4 & 3.7 & 6.5 & 4.1 \\
\hline UAE & 4.3 & 3.9 & 5.7 & 4.0 \\
\hline Israel & 3.9 & 4.7 & 3.9 & 3.4 \\
\hline Malta & 3.5 & 2.8 & 3.2 & 4.1 \\
\hline Regional Average & 5.1 & 4.9 & 6.3 & 4.8 \\
\hline Global Average & 4.8 & 4.7 & 5.0 & 4.8 \\
\hline
\end{tabular}

TABle i: Middle East and North Africa (MENA) Rankings

contextualized. In our own work, we have found that except for the most severe cases of fragility, countries are rarely extremely deficient in all of their ALC components. Such an observation underscores the variety of ways in which states exhibit fragility, and supports the utility of the ALC approach in highlighting different situations. We have also found it extremely helpful to profile countries along different clusters that include governance, economics, security and crime, human development, demography, and environment. It is not uncommon for countries with relatively similar fragility scores to behave quite differently along these different indicator clusters, thus further highlighting strengths and weaknesses, as well as entry points for policy actions. Furthermore, using quantitative indicators at the structural level, in combination with dynamic analysis or events-based monitoring and qualitative assessments that are timely in order to provide a full picture of what is happening in-country, can provide further nuance and contextualization for policy actions.

Second, although "doing no harm" makes sense in theory as a principle, in reality the practice is quite different. As an example, consider the recent elections that were held in the extremely fragile state of Haiti, where the underlying assumption (and source of confusion) is that democratic elections can buy legitimacy. All that these elections have done has been to further de- 
stabilize a country that has hardly recovered from the tragic January 12, 2010, earthquake. In fact, only a quarter of Haiti's registered voters turned out for the elections, which were reported to have cost around US\$30 million, and the first-round results were subjected to much criticism. It would have made far more sense to strengthen state institutions and work with the current, albeit weak, government to deliver basic services to the population, and gradually build legitimacy before holding elections later.

Third, and related to the second point, the timing and the sequencing of policies are crucial. On the one hand, focusing on state-building as the main objective, as recommended by the Organization for Economic Cooperation and Development (OECD), makes sense, but only for those countries where legitimacy is weak. On the other hand, some states can be strong but lacking in capacity; after all, many democracies in Africa, Asia, and Latin America have been overthrown and replaced by authoritarian regimes because of their failure to deliver economic development. Two findings from our work are crucial here. To the extent that the level of development is a highly significant determinant of fragility, growth should be prioritized, even if other factors such as regime type and trade openness matter. Furthermore, in the most severe cases of fragility, where sudden changes in authority structures are highly destabilizing and independent of changes in capacity structures, specific instruments targeting individual weaknesses are required, rather than focusing on security and hoping development will follow.

However, in situations where fragility is not extreme, strategic timing and preventive diplomacy may be more appropriate for particular areas because of the positive feedback that they create for other weak areas. Our point is not to disagree with state-building as a concept but to argue that interventions need to be context-specific and timed properly and strategically.

Fourth, alignment with local priorities, coordination among international actors, acting fast but staying engaged for a long period of time, and avoiding pockets of exclusion, as recommended by the OECD, are all sensible in theory. In practice, these objectives are far from being met. Although donors should strive to work with governments as much as possible to help them build legitimacy and capacity to deliver basic services, governments sometimes need to be bypassed and aid provided through different channels. Furthermore, aid dollars need to be systematically monitored by the deployment of impact-assessment tools, and we need to be ready to withdraw or suspend aid when results are not satisfactory. The proliferation of donor agencies and lack of coordination among them is still a pressing problem, leading to the duplication of efforts. In this respect, the use of multidonor trust funds, for example, should be further encouraged. 
As far as avoiding exclusion, in looking at aid allocation among fragile states, it is still the case that fragile states are underaided as a group when compared to other aid recipients. Within the group of the most fragile states, one can find both aid darlings and aid orphans, with some countries being overfunded with respect to absorptive capacity. For example, the top five recipients of aid among the forty-three fragile states identified by the International Network for Children and Families (INCAF) received more than half of the aid allocated in 2008, despite representing only about 20 percent of the population living in these fragile states. It is quite likely that some of these countries are receiving more aid than they can absorb effectively. In our view, too much emphasis is still placed, generally as well as in the case of fragile states, on the quantity, rather than the quality, of aid delivered. More specifically, the relationship between fragility and democracy in both countries is clearly complex, but suffice it to say that neither has enjoyed fully open participatory systems. Countries with highly functional democratic processes are indeed stable, but then so are deeply entrenched repressive regimes; Zimbabwe and Pakistan as partial democracies lie somewhere in between. Therein lies the problem, because the most unstable countries are those with moderate levels of democratic performance. This presents a challenge to efforts to move repressive regimes toward more open and participatory forms of governance. One must understand the nature of the problem at hand in order to develop pragmatic policies that will target problems without setting off chain reactions of disturbance. ${ }^{14}$

These findings are intuitively plausible. Increased democratic participation in autocratic or authoritarian states may provide valuable guidance for government policy, not to mention reduce literal barriers to commerce such as restrictions on citizen movement or assembly. However, truly responsive democratic governments are more likely to produce policies addressing popular concerns that are not growth-focused, such as regional wealth distribution and social programming focusing on minority interests. This is not to say that democracy is a bad thing, only that it should not be treated as a magic bullet that will solve all of a developing country's problems. Concentrating on accountability, transparency, and predictable rules governing economic interaction is more likely to produce greater wealth and increased distribution. Higher levels of wealth do correlate with stronger democracies, suggesting that putting elections ahead of growth may ultimately be an inefficient use of resources even if well-intentioned. Having examined some of the issues related to both sequencing and timing from a case-specific perspective, we now turn to an evaluation of the large sample empirics.

We have three recommendations for policymakers working in fragile-state situations. First, support policy-relevant analysis. It has been argued many 
times before that a key problem in responding to fragility and failure is not the availability of information or, for that matter, the absence of early warning information, but the absence of a clear understanding of how to make diagnosis policy relevant. In this regard and as we have shown, risk analysis and early warning need to be practicable, standardized, and accessible. In other words, the absence of a clear understanding of how specific information fits within the operational capacities of the end user is the most significant constraint on effective conflict prevention. Properly understood policy-relevant diagnosis combines real-time dynamic analysis with structural information, matches the analysis to the operational capacity of the end user, and provides an evaluative framework for assessing policy impact.

Second, make prevention pay. Political will, or, more specifically, its absence, is the number one justification for failing to respond to impending and foreseeable disaster. Making prevention pay means that the costs (and risks) of inaction must be fully calculated and clearly communicated. It also means that institutional incentive structures must be better developed to ensure better coordination across departments and between governments. Pooling of resources is one way to assist in the process of identifying costed options, but this must be achieved at both the micro and the macro levels. Coordination means that program officers from different departments should work effectively together as a problem-solving team and not in isolation.

Third, integrate findings and methodologies across research communities. There is a lot of good, mostly complementary, analysis, both in academe and advocacy circles, on fragility and failure. Some analysis and research finds its way into the policy community, but not much of it is linked together in a formal institutionalized way with ongoing and secure funding. When it is used, fragility analysis tends be drawn on in an ad hoc and selective way. As a result, key findings remain underutilized, and researchers have little incentive to collaborate among themselves and with the policy community. More hazardous is a trend within government toward individually tailored in-house analytical tools, with each department advocating a distinct set of indicators, tool kits, and set of assumptions about causal connections that support their agendas.

\section{NOTES}

1. CIFP uses statistical measures of the aforementioned ALC components corresponding to six different categories of state performance: economics, governance, security and crime, human development, demographics, and the environment. For definitions, rankings, and indicator measurement, see www.carleton.ca/cifp. 
2. Myron Weiner, “The Macedonian Syndrome: An Historical Model of International Relations and Political Development," World Politics 23, no. 4 (July 1971): 665-83.

3. See Lisa Chauvet, Paul Collier, and Anke Hoeffler, "The Cost of Failing States and the Limits to Sovereignty" (UNU-WIDER Research Paper, no. 2007-30).

4. United Nations Development Programme, Human Development Report 2009: Overcoming Barriers; Human Mobility and Development, http://hdr.undp. org/en/content/human-development-report-2009.

5. FAO Newsroom, "Haiti at Crossroads," December 18, 2006, http://www. reliefweb.int/rw/RWB.NSF/db900SID/EGUA-6WLL9Z?OpenDocument; and Sonia Verma, "Aid in Haïti a 'Logistical Nightmare," Toronto Star, September 25, 2004.

6. The above data and analysis draw directly from David Carment and Yiagadeesen Samy, "Haiti without Tears: Getting Aid Right," Policy Options 31, no. 4 (April 2010): 57-63.

7. See International Monetary Fund, "Haiti: Debt Statistics and IMF Support," January 27, 2010, http://www.imf.org/external/np/country/2010/012710.htm.

8. Alexa Barrera, Sonia Bouffard, Andrew Harrington, and Per Unheim, "Jamaica: A Risk Assessment Brief," Country Indicators for Foreign Policy (CIFP), February 2006, http://www4.carleton.ca/cifp/app/serve.php/1241.pdf.

9. Portions of this analysis are drawn from David Carment, "The New Terrorism: Understanding Yemen," Canadian Defence and Foreign Affairs Institute, March 2011, www.cdfai.org.

10. For a full description of these indicators and the sources from which they are drawn, see Country Indicators for Foreign Policy (CIFP), http://www.carleton .ca/cifp/ffs_indicator_descriptions.htm.

11. See Nicole Alie, Mahsa Hedayati, Amy Keuhl, and Nathan Lysons, "Yemen: A Risk Assessment Report," Country Indicators for Foreign Policy (CIFP), 2007, http://www.carleton.ca/cifp/app/serve.php/1338.pdf.

12. The data in this report shows that people are not demonstrating for just a lack of economic opportunity or poor social services. They have been challenging the very legitimacy of the regime itself. Canadian Defence and Foreign Affairs Institute, http://www.cdfai.org/PDF/Social\%20Underpinnings $\% 20$ of $\% 20$ Unrest .pdf.

13. See David Carment, Stewart Prest, and Yiagadeesen Samy, Security, Development, and the Fragile State: Bridging the Gap between Theory and Policy (New York: Routledge, 2010).

14. In autocratic countries, some democratic opening correlates with higher economic growth. However, research shows that in countries that enjoy low levels of democracy, further increases in political freedoms and responsiveness actually correlate with reduced economic growth. With these two ideas in mind, the answer to whether democracy stimulates economic growth appears to depend on context; a little is good, but a little more may cause harm. 


\section{REFERENCES}

Alie, Nicole, Mahsa Hedayati, Amy Keuhl, and Nathan Lysons. "Yemen: A Risk Assessment Report." Country Indicators for Foreign Policy (CIFP), 2007. http://www.carleton.ca/cifp/app/serve.php/1338.pdf.

Barrera, Alexa, Sonia Bouffard, Andrew Harrington, and Per Unheim. "Jamaica: A Risk Assessment Brief." Country Indicators for Foreign Policy (CIFP), February 2006. http://www4.carleton.ca/cifp/app/serve.php/1241.pdf.

Carment, David. "The New Terrorism: Understanding Yemen." Canadian Defence and Foreign Affairs Institute, March 2011. www.cdfai.org.

Carment, David, Stewart Prest, and Yiagadeesen Samy. Security, Development, and the Fragile State: Bridging the Gap between Theory and Policy. New York: Routledge, 2010.

Carment, David, and Yiagadeesen Samy. "Haiti without Tears: Getting Aid Right." Policy Options 31, no. 4 (April 2010): 57-63.

Chauvet, Lisa, Paul Collier, and Anke Hoeffler. "The Cost of Failing States and the Limits to Sovereignty." UNU-WIDER Research Paper, no. 2007-30.

FAO Newsroom. "Haiti at Crossroads," December 18, 2006. http://www.reliefweb .int/rw/RWB.NSF/db900SID/EGUA-6WLL9Z?OpenDocument.

International Monetary Fund. "Haiti: Debt Statistics and IMF Support," January 27, 2010. http://www.imf.org/external/np/country/2010/012710.htm.

United Nations Development Programme. Human Development Report 2009: Overcoming Barriers; Human Mobility and Development. http://hdr.undp.org/ en/content/human-development-report-2009.

Verma, Sonia. "Aid in Haïti a 'Logistical Nightmare." Toronto Star, September 25, 2004.

Weiner, Myron. "The Macedonian Syndrome: An Historical Model of International Relations and Political Development." World Politics 23, no. 4 (July 1971): 665-83. 


\title{
CHAPTER 2
}

\section{Human Rights and Wrongs in Failed States}

\author{
Bosnia-Herzegovina, the International Community, \\ and the Challenges of Long-term Instability in \\ Southeastern Europe
}

\section{T. DAVID Curp}

Europe has no exit strategy for Bosnia.

—Gerhard Spörl, Spiegel

In this chapter I will briefly survey both the recent history of and several key problems confronting the nested Matryoshka doll of weak and incompetent states currently attempting to exercise sovereignty in the former Bosnia-the (Serbian) Republika Srpska; the Muslim-Croat confederation (which is effectively divided between the de facto independent Croatian Herceg-Bosna statelet and a Bosnian Muslim/Bosniak ministate); the central government of Bosnia headquartered in Sarajevo; and the host of international bodies and NGOs tasked with peace-building and reconstruction. These states and the constellation of outside powers and organizations that seek to maintain the peace in Bosnia would seem eerily familiar to a bureaucrat of the Holy Roman Empire. ${ }^{1}$

In Bosnia, leading European countries in cooperation with the United States appeared to have been so enamored of the options that Gen. Anthony Zinni has argued confront outsider powers contemplating a response to a civil war-that one must either not intervene, choose a side, or separate the parties - that they implemented all three, initially in that order. For more 
than four years, from 1991 to 1995, divided Western policies and hesitancy to get involved led to an international paralysis that allowed the heavily armed Bosnian-Serbian nationalist factions to effectively conquer and ethnically cleanse much of the country. In 1995 Bosnian-Serbian atrocities, from the ongoing attacks on Sarajevo to the assaults on UN safe areas-particularly the massacre in Srebrenica-helped trigger a massive NATO intervention that forcibly brought the warring factions to peace talks at Wright-Patterson Air Force Base in Dayton, Ohio-a place chosen in part because it was so bleak that the parties would be forced to focus on the work of peacemaking rather than enjoying the delights and distractions of a larger, better appointed urban environment. $^{2}$

The Dayton Accords (brokered in part with the indispensable assistance of both Slobodan Milošević and Franjo Tuđman ) resulted in a durable peace that set the stage for a massive NATO military presence in that country, saw the creation of a federal Bosnian constitution and government, and included an agreement by the various Bosnian factions to embrace a series of international objectives intended to put that country on the road to postwar recovery-including the right of refugees who had suffered ethnic cleansing to return to their homes. To support these ends, in addition to military forces, the European Union and the international community deployed a not-sosmall army of multinational organizations, NGOs, and quangos (quasinongovernmental organizations) to further the redevelopment of Bosnia. The result over the past fifteen years has been the creation of a (mostly) peaceful quagmire- highly expensive, deeply corrupt, and potentially quite volatile - such that Günter Verheugen, until recently a commissioner of the EU for more than a decade, remarked that Bosnia represents "an almost insoluble problem" 3 for Europe.

How and why has the work of a whole range of well-funded and wellintended initiatives failed so completely in Bosnia, and what are the results and implications of this failure? I will consider three distinct aspects of the problem: First, the ways in which the conduct of both local and international actors during and after Bosnia's civil war created conditions that have created insoluble dilemmas for all concerned in achieving any of their core objectives. Second, I will examine three distinct areas where both indigenous and exogenous efforts to spur development and respect for human rights have done more harm than good in Bosnia - the provision of generous foreign aid and the ongoing internationally-sponsored prosecutions of war criminals, and the continued development of religious life. I will conclude by analyzing how these cumulative, expensive failures have built upon one another and suggest that there are larger and deeper failed-state problems in Europe than Bosnia 
alone-problems rooted in both the humanitarian extremism and the dysfunctions of the European community.

\section{A SERIES OF UNFORTUNATE EVENTS: THE HISTORY OF YUGOSLAVIA'S AND BOSNIA'S WARTIME AND POSTWAR DISINTEGRATION}

If the international community is not willing to abide by its own principles when faced with major difficulties, what can we expect from local politicians? (From the Council of Europe's criticism of the reform of Bosnia's judiciary by the Office of the High Representative $)^{4}$

A thorough examination of the various problems created by Western indecision and the conduct of Bosnia's civil war locally is outside the scope of this narrative. I will, however, draw attention to two aspects of the conflict that helped set the stage for some of Bosnia's deeper postwar pathologies. The first of these is the relative military incompetence of the Izetbegovic administration in Bosnia. It should be noted that this incompetence to some degree is very much to the credit of former president Alija Izetbegović, who (in an almost suicidal fashion) resisted until the last moment the militarization of Bosnia's secession from Yugoslavia. Yet, while the efforts of Izetbegović to find a peaceful resolution to Bosnia's move to independence demonstrated how ruthless was the Serbian effort to subvert democracy through force of arms, the effects of the president's failures were deep and long-lasting. By actively hindering Bosniak self-defense through the surrender of arms to the Yugoslav People's Army (henceforth JNA [Jugoslovenska Narodna Armija]), even as Serb forces began their attack on Bosnia in the summer of 1992, President Izetbegović effectively facilitated the Bosnian-Serb blitzkrieg that put over 70 percent of the area of the republic under Serb control by the fall of 1992. ${ }^{5}$ Furthermore, the failure to prepare for a military conflict - that both Serbian actions prior to the fall of Yugoslavia and JNA assaults on Slovenia and especially Croatia had telegraphed (combined with the impact of the UN-sponsored arms embargo - see below), deepened both the Izetbegović administration's dependence upon criminal elements and further alienated Bosnian Croats (and even some Bosniaks) ${ }^{6}$ from the government in Sarajevo, setting the stage for the civil war that almost destroyed Bosnia within its first year of existence and further tied already strongly pro-Zagreb Bosnian Croatians more closely to the Tuđman regime than to Sarajevo.

Second, the role of the UN-sponsored, EU-supported arms blockade upon Bosnia and the international community played a key role in undermining the Bosnian state, facilitating Bosnian Serb victories, and increasing - if that 
were possible-contempt for the UN both locally and internationally among those policymakers who effectively maneuvered around the embargo. The naive and destructive belief that a blockade on arms would somehow help limit or contain the conflict did more than provide a major advantage to Serbian aggressors throughout most of the war-it also of necessity forced the Bosnian Croatian and Bosniak authorities and their ostensible Croatian allies to develop smuggling networks that deepened the nexus between organized crime, national defense, and political power brokers in both communities. ${ }^{7}$ These ties have proved enduring and represent another major barrier to economic (and police) reform in Bosnia. Furthermore, the Clinton administration, which was deeply at odds with this policy, circumvented it through clandestine contacts with Iran, which smuggled weapons to Bosnia through Croatia. These policies in turn further strengthened the political dependency of both the United States and Bosnia on Tuđman's Croatia. ${ }^{8}$ Not only did this move enhance the Croatian military's capacity to wage war through that country's "cut" on all Iranian arms it received and then transshipped to Bosnian forces, it also represented a signal to that country's leadership that the United States would not allow UN policies and the expressed will of the international community to constrain the requirements of a "humanitarian" realpolitik. The eventual Croatian-facilitated, NATO-supported military victory that emerged in the summer of 1995 both in Bosnia and in Croatia would set the stage for the kind of peace that would be fashioned in Dayton.

The Dayton Accords as well as their initial implementation reflected the kind of minimalist, low-cost, low-risk approach that had driven the broader international community's various policies toward the former Yugoslavia since the beginning of its breakup. The consensus that the Dayton settlement legitimized Bosnia’s partition (and even Slobodan Miloševićs role as a "peacebroker") need not be elaborated here. ${ }^{9}$ During the first postwar decade, even as the international community transformed Bosnia into a "semi-protectorate," flooded the region with aid, and (reluctantly) expanded NATO and the European community's role in Kosovo, contradictions continued to beset the international community's peace-building efforts. Two contradictions of the "semi-protectorate" that complemented preexisting (prewar and wartime) fault lines in Bosnia are worth attending to: the complementary relationship between the growing and diverging authority, power, and jurisdiction of both Bosnia's various nationalist parties and the Office of the High Representative.

The growth of nationalist parties throughout the former Bosnia and Herzegovina for much of the last fifteen years is hardly unique to the Balkans. As Valery Tishkov has argued in relation to Chechnya, persistent violence and intervention can help induce a sociopolitical "demodernization." 10 
The realities of this postconflict demodernization make Bosnia's status as a semi-protectorate and the unilateral expansion of the international community's authority (formally vested in the Peace Implementation Council [PIC]) in the region through the so-called "Bonn Powers," which, in December 1998, granted the (formally weak) high representative (henceforth HR) "unlimited authority to impose laws at any constitutional level, and to dismiss elected representatives, political party officers and public officials." 11 As a number of analysts of the situation in Bosnia have noted, the HR's expanded powers (and the increasingly expansive-and unaccountable - use of them made by most high commissioners) have created a symbiotic relationship between nationalist (and other) parties and the HR. Local political authorities can defer or avoid unpleasant policy choices by deferring to the HR. The HR, in turn, can (and does) point to the toxicity and irresponsibility of the Bosnian political environment as a sign of the ongoing importance of this position and its maintaining untrammeled authority. The result is a remarkably efficient vicious circle that is almost as politically devastating as the demodernization that sustained conflict can induce, perhaps even more so for enjoying the imprimatur of the international community. ${ }^{12}$

\section{A PROFUSION OF GOOD INTENTIONS: SEEKING MONEY, JUSTICE, AND GOD IN A POST-HUMANITARIAN CRISIS}

The EU has always preferred the path of the short term, anything to avoid a crisis rather than facing up to the issues. (Paddy Ashdown, former high representative to Bosnia, describing the political situation in May 2010) $)^{13}$

Bosnia's transition from a constituent republic of Yugoslavia to a de facto international protectorate during almost twenty years of war-making and peace-building has fractured the country in multiple ways. Each fracture, in turn, both has hampered efforts at state-building and recovery from the war and continues to distort other aspects of social, cultural, and economic life. Three key areas of social, political, and cultural life that are especially weighted down with the burdens imposed upon them by Bosnia's (and the international community's) history and that interact with one another in dynamic and largely destructive ways are (1) the failure of economic development; (2) ongoing alienation from judicial institutions; and (3) the massive revival of divided religious institutions in the midst of deep political cleavages. Any one of these issues has the power to undermine Bosnia's 
state-building and recovery-but their collective disequilibrium, along with the numerous missteps of the international community, does a great deal to ensure that Bosnia remains an ongoing experiment in intervention, and an incompetent, if not a failed, state.

European aid and other outside assistance has been massive, generous, and regular. ${ }^{14}$ Over the past fifteen years, in a country the size of Tennessee with a population of a little over four million people, the EU alone has spent more than $€ 25$ billion (almost equally divided between reconstruction and the salaries of aid workers ${ }^{15}$ ) in Bosnia, exclusive of the (considerable) costs of providing security since $1995 .{ }^{16}$ While the needs of Bosnia after almost four years of war were severe-especially considering the previous, Tito-era poverty-stricken status of the republic and the wartime internal displacement of more than 60 percent of Bosnia's population-the scale and continuing nature of outside financial aid has distorted Bosnia's economy (more aid per capita than has ever been spent in any postconflict situation-see below ${ }^{17}$ ). Observers have noted that Bosnian public expenditures-which run at more than 50 percent of the country's GDP (including transfer payments to individuals for veterans and other pension benefits that regularly consume hundreds of millions of euros annually) — have remained at "unsustainable" levels for over a decade. Yet, according to the World Bank, state-provided transfer payments "are barely reaching the country's poorest citizens and there is little evidence of poverty reduction." 18

The high public expenditures and public sector employment mirror-image the various aid bureaucracies in European Union and OECD support. The support of the latter institutions, in addition to modeling a bloated style of governance that Bosnia cannot sustain (and absorbing many of those Bosnians most adept in foreign languages), has also fostered what the economist Laza Kekic has termed "aid addiction" in Bosnia. According to Kekic, in the current situation the sheer scale of aid and its "pushers" have stifled local economic initiative, provided subsistence without employment for most of Bosnia's population, and has led to the virtual occupation of Bosnia by a highly trained and well-compensated EU soft-power "expeditionary force" (even as the country has experienced a substantial brain drain of educated Bosnians looking for opportunities abroad). ${ }^{19}$

In regard to supporting Bosnian efforts to establish the rule of law, the track record of outside supporters has been even less successful and contributed further to maintaining and deepening Bosnia's divisions. Three sets of legal problems loom particularly large and include (1) the international recognition of Kosovo independence, which has fueled the popularity of and claims by the nationalist leadership of Bosnia's Republika Srpska that they, 
too, are entitled to secede from Bosnia; (2) the inability of local, national, or international political actors to implement the right of refugees to return to their former homes, even as they successfully adjudicate property ownership between ethnic groups; and (3) the more deeply divisive question of securing justice against war criminals. The multiple international failures on these fronts accentuate local feelings of betrayal and humiliation of many Bosnians who feel victimized at the hands of both prosperous war criminals still in their midst and the international community that is unable to deal with them. This in turn reinforces a local sense of entitlement by an aggrieved, victimized population that acts as if continued European aid and security assistance are legitimate forms of reparation for the wrongs they have suffered.

The legal, political, and philosophical questions tied up with the international recognition of Kosovo's independence (exacerbated by the ongoing political deadlock) have produced numerous political crises in Bosnia and Herzegovina over the last several years, particularly between the Office of the High Representative and the president of the Republika Srpska. The international community, having gone from insisting at the beginning of their intervention that Kosovo would remain an integral part of Serbia to reneging on that commitment, has emboldened the president of Republika Srpska, Milorad Dodik, to insist upon the right of Serbs to secede from Bosnia. Dodik, who, prior to his apparent conversion to nationalist politics was a Social Democrat, successful reformer ${ }^{20}$ and "darling of the international community," has, since his 2006 election (which reinforced ethnic polarization in all three of Bosnia's major ethno-national communities), ${ }^{21}$ threatened on several occasions to call a referendum on the issue of statehood for Republika Srpska ${ }^{22}$ The ease with which President Dodik tacks back and forth between defending the status of Republika Srpska as enshrined in the Dayton Accords and demanding that Serbs have the same right to self-determination as Bosnia enjoyed in 1992 (or Kosovo received from the international community) demonstrates both continuity in and deepening of Serb alienation to Bosnia. This stance also reveals the contradictions in the stance of an international community that claims to support democratic governance in the western Balkans, but apparently only to the degree to which democracy conforms to predetermined outcomes. ${ }^{23}$

The international community's efforts to enforce justice often further intensify a sense of alienation and unreality among the various inhabitants of Bosnia. For example, Bosnian Muslims regard efforts to prosecute war criminals from their communities as perverse, since Bosnian soldiers made war under the shadow of ethnic cleansing and possible genocide—hence for 
Bosniaks any effort to equate their defense of their communities, even when it involved atrocities, cannot justly be compared to Serbian or Croat crimes. The international community's insistence that Bosniak soldiers be put on trial for war crimes even as it had failed for much of the last fifteen years to find even the most important of Bosnian Serbian war criminals such as Radovan Karadžić (captured only in 2008) and General Ratko Mladić (the butcher of Srebernica who was at large until July 2011-even though, at least via Wikileaks, we know that some European diplomatic personnel are convinced that the Serbian government was well aware of his location)does little to encourage Bosniak compliance with or sympathy toward international concepts of justice.

Legal issues related to the right of refugee return and compensation for stolen or confiscated property also reflect a perverse logic. The relatively greater efficiency of some NGO and official European organizations in interacting with their local Bosnian counterparts often works at variance to the broader goals of the Dayton Accords. General Anthony Zinni opened up a particularly terrifying window onto the dilemmas of war- and peacemaking in our thoroughly wired and technologically savvy world when he spoke of a concept of which the American military is increasingly aware-that of the "strategic corporal," ${ }^{24}$ or, for civilian purposes, the Fadia Hamdi effect (the Tunisian policewoman who slapped the street vendor Mohammed Bouazizi, whose self-immolation became the spark for the Arab Spring). In the current age of global news and a wired world order, even the lowest-level functionary or soldier has the ability to create a media firestorm through one unconsidered rude or ill-timed act that can cause incalculable damage.

In Bosnia, the problems that confronted the international community and refugee organizations were the "strategic alderman," the "strategic town clerk," and the "strategic sheriff"-local officials who, in collusion with significant elements of the local population, had effectively nullified the right of return by helping to continue to fan the flames of local nationalist hostility. While unable to oppose low-level officials directly, the ability of NGO and EU officials' effectiveness in negotiating compensation of property for the expellees with these same officials thoroughly reinforced and solidified the results of ethnic cleansing-refugees who had received financial compensation for their confiscated property (whose possession they could not enjoy since this would involve living among hostile neighbors) were even less likely to return to areas from which they were expelled; while those who benefited from the ethnic cleansing became more firmly established in the property their government stole for them on behalf of their nation. The legal international imprimatur on this process (paid for at least indirectly through the international community's 
heavy subsidies of the various national enclaves) only adds to the legitimization of ethnic cleansing, the sense of abandonment and alienation of many expellees toward those providing them aid, and, further, helps to permanently cement Bosnia's ethno-national divisions. ${ }^{25}$

Finally, religious developments are among the more unsettling areas of NGO activity in Bosnia. Even where there is no intention on the part of either religious leaders or ordinary believers to undermine the Bosnian state, both the region's social and cultural dynamics and history interact with the remarkable resurgence of post-Yugoslav religion in such a way as to further undermine efforts at state-building. ${ }^{26}$ Religious life has commanded most attention regionally over much of the last two decades due to international concern related to the potential for Islamic radicalization among Bosniaks. ${ }^{27}$ This concern is heightened by the ongoing (if reduced) presence of foreign mujahideen, some of whom had connections to al-Qaeda as well as the ongoing stream of money, missionaries, and mosque-building aid from Saudi Arabia, Iran, and Turkey to Bosnia. ${ }^{28}$

Though there have been some minor instances of jihadist recruitment and activity in Bosnia for much of the last fifteen years (and a wider rejection of jihadist efforts either to recruit locally or to maintain a mujahideen presence in Bosnia), more important has been an even greater increase in both Islamic social and cultural activism and a general deepening of religious practice among a Bosniak population that prior to 1992 was not renowned for its strict ritual adherence. The real transformations of Bosnian Islam are not due to the tiny minority of Bosniaks turning to jihadist ideologies. Rather, ironically, much like Catholicism and Orthodoxy regionally, religious transformations are caused by the increasing power and visibility of faith in the public square, religious leaders' transnational engagement with coreligionists abroad, and the role of both religious leaders and ordinary believers in maintaining and even strengthening their faiths' war-forged alliance with ethno-nationalist political movements.

The desecularization and sacralization of public life has developed throughout Bosnia (and much of the rest of the former Yugoslavia as well) for much of the last twenty years. ${ }^{29}$ For Bosniaks, a variety of factors, particularly their experiences as victims of ethnic cleansing and of genocide, has led to a unique blending of Islam and national identity. Furthermore, in both war and peace, even as Bosniaks have found themselves at odds with their Christian neighbors, they have become much more connected to Muslims around the world. Embassies from Muslim countries, especially Iran and Saudi Arabia, as well as Muslim relief organizations, have played a major role in providing various forms of aid, from mosque reconstruction, donations of (mostly) religious literature, and support for young Bosniaks 
to study in universities around the Muslim world, as well as the organization of cultural events. ${ }^{30}$

Among Bosnian Christians there has been a parallel double movement of religion both outward to coreligionists abroad and expansive politically, socially, and culturally at home. Michael Sells has argued that something like a religious apartheid against non-Catholics has obtained in Herzegovinian Bosnia ${ }^{31}$ - a development exacerbated by the importance of the famous Marian shrine at Medjugorje, whose presence on Bosnian soil for some Bosnian Croatians (and their conationals in Croatia) makes the unification of the Croatian portions of Bosnia and the "motherland" a religious necessity. ${ }^{32}$ Secular Serbian scholars have discussed the general "desecularization" of Serbian society ${ }^{33}$ and the significant impact of the development of Orthodox religious education among the youth of the Republika Srpska, as well as the religious impact of the secession of an Albanian-dominated Kosovo (and subsequent destruction of Serbian religious shrines in that country). Religious revival and deepening ties with coreligionists have created a cultural and social map that differs a great deal from the formal political geography of Bosnia.

Two further, deeper problems complicate the role of religious actors (as well as those who would seek to build a secular state) in Bosnia. The first is that the widespread perception that secular international and domestic political institutions and actors are corrupt and have failed has further enhanced the authority of religious actors. ${ }^{34}$ Second, the multiple contradictions implicit in the OHR's and the European Union's policies - the tension between democratic state-building and maintaining Bosnia as a dependent region, of seeking "truth" and reconciliation, the repeated OHR promises and threats tied to Bosnia's potential EU membership that recedes further into the future-stand in stark contrast to the clear and rhetorically powerful, if not always insightful or healing, statements of foreign or domestic religious figures. ${ }^{35}$ The wellmeaning symbolic efforts first of UNPROFOR (United Nations Protection Force), and later of secular NGOS, the Office of the High Representative, and $\mathrm{UN}$ troops and personnel in Bosnia, to engage (on a limited basis) religious believers or to create alternative secular symbols of order and stability such as the rebuilding of the famous Mostar bridge, or the less well-meaning role of UNPROFOR and later UN troops in human trafficking and prostitution locally, have created potent antisymbols of secular life. ${ }^{36}$ This authority, since it is mostly negative, however-relying upon the failure of secular international and domestic actors-buttresses religious sensibilities and authority, which need not engage in constructive activity. ${ }^{37}$ The result is further division of an already shattered polity. 


\section{SITUATION NOT URGENT, SIMPLY TRAGIC: STATE FAILURES AND/OR SYSTEMIC FAILURES}

"It must be very frustrating for you not to accomplish anything. Why don't you simply leave?" I asked.

He answered: "Yes, it is frustrating. But if I go back to New York, even though I will have a nice office and a very good position, I will be just another insignificant bureaucrat. Staying here is exciting, and makes me feel important." (Dzenita Mehic's report of a conversation with a "prominent UNPROFOR official") ${ }^{38}$

Time need not heal any wounds. In Bosnia the fictions of successful humanitarian intervention (which masked American and European sanction of Bosnian Serb ethnic cleansing), of federal Bosnian unity (that has brought about no effective integration between numerous mini- and micro-political entities), and of a progressive European protectorate (that has not stabilized Bosnia in spite of massive expenditures of work and money and in spite of having the virtually untrammeled political power of the Office of the High Representative) have all produced a bloodless quagmire. Few to no lives are lost to the violence of war, but the political, cultural, social, and even economic costs of this desert called peace are nonetheless severe.

One problem is the interrelationships between the international community's fictions of successful engagement to end ethnic cleansing (as opposed to ratifying its results) and promote international law, NGO and European self-interest in maintaining a perpetually dependent Bosnian protectorate, and the local vitality among many Bosnians of mutually exclusive hostile nationalisms, religious revival, and economic corruption. For many aid workers and European officials, UNPROFOR's and Europe's Bosnian protectorate has been a steady source of employment, career development, and even symbolic justification of the importance of international institutions-and has been perceived as such by many locally. Even worse, the increasingly visible "enlargement fatigue" in many countries within the European Union (clear even prior to the financial crisis that exacerbated this fatigue ${ }^{39}$ ) is making the most important "carrot" possessed by European entities—-membership in the EUin Bosnia appear increasingly unobtainable.

Furthermore, the persistent "underestimation" of the power of religion to motivate the "angry young men" (and many women who love and use them/ are loved and used by them and who also suffered and invested greatly in the struggles that tore Bosnia apart) also represents a too often missed opportunity to tie international initiatives more closely to local supporters rooted in the 
social and cultural lives of their communities. The for too long overly secular nature of the international community's engagements in Bosnia represents a dangerous blind spot, since religious ideals of justice, mutual aid, community, and alienation all represent a "bully pulpit." ${ }^{40}$ This limited but real power of religion, if engaged respectfully and with careful attention to the concerns, values, and prejudices/limitations of religious elites as well as "ordinary" lay believers, is well positioned to advocate for a vision of the future different from the ones currently being proposed in Bosnia.

The international community has grown used to having, proposing, and often imposing its own truths. Throughout the Western world our ability to consider World War II the "good war," though it involved close collaboration with a Soviet regime that had itself been guilty of mass murder, is something that produced little if any cognitive dissonance for American or most West European consciences for generations-a point of view that is deeply contested from the Oder River to Kamchatka. Yet our efforts at imposing our truths-be they the inherent stability and vitality of a multicultural society (one of our newest intellectual fashions ${ }^{41}$ ) or the necessity of letting bygones be bygones (no matter how horrific the injustice)—often require compromises, if only because our willingness to bend as much of our power as would be necessary to impose such truths is limited. These compromises in turn become the grounds for further alienation and incomprehension of Western goals, methods, and beliefs.

In conclusion, the weakness of state structures in Bosnia is an intensely local problem rooted in recent history where conflict narratives and political solidarities brought into being by criminals and patriots (including many criminal-patriots), as well as a majority of ordinary people in high and low places, not only destroyed the old Yugoslavia but continue to mutually reinforce one another's efforts to destroy even the ideal of mutual coexistence much less solidarity among the different communities of Bosnia. While that is a local tragedy, there is a problem of another form of state failure that the past and current situation of Bosnia brings to the fore that is much more urgent to address - that of the post-Cold War policies of the Western community (especially those of NATO, the EC/EU, and the United Nations) and the international aid community. The inability of Europe's most well-funded, technologically sophisticated, and culturally/politically legitimate states, institutions, and military forces to enact effective strategies of development, reconciliation, and state-building in a region where their own interests are deeply engaged, their resources are more than sufficient (and near at hand), and their familiarity with local conditions should be at their greatest (relative to other regions), is a sign of state failure and incompetence that has implications far 
more serious than the civil war and disintegration of the former Yugoslavia. If in what, relative to most other postconflict regions, are all but ideal conditions of regional peace and stability, efforts at rebuilding Bosnia have proved to be such an expensive and seemingly insoluble enterprise, what realistic hope is there for restoring peace and effectively reconstructing shattered societies in other, less well-developed, more instable regions? A decomposing Bosnia, in the "belly of the (first world) beast" for more than twenty years, has demonstrated the limits of the military, political, and economic competence of the United States, NATO, the European Union, and the United Nations. What we have yet to do is to begin to evaluate, much less remedy, the collective incompetence and failings of those states and institutions that are seeking to maintain international order.

\section{NOTES}

1. Sumantra Bose, Bosnia after Dayton: Nationalist Partition and International Intervention (New York: Oxford University Press, 2006), 60-68. At various levels of governance the principles of representative democracy coexist with ethnonational power-sharing, up to authorizing different entities within the Bosnian state—such as the Republika Srpska—and to develop "special parallel relationships with neighboring states."

2. Derek Chollet, The Road to the Dayton Accords: A Study of American Statecraft (New York: Palgrave MacMillan, 2005), 121, 133-38.

3. "Former European Commissioner Günter Verheugen: The EU 'Has No Vision of Where We Are Heading," Spiegel Online International, February 9, 2010, http://www.spiegel.de/international/europe/0,1518,676784,00.html.

4. Gerald Knaus and Felix Martin, "Travails of the European Raj," Journal of Democracy 14, no. 3 (July 2003): 65.

5. Marko Attila Hoare, How Bosnia Armed (London: Saqi Books, 2004), 44-49.

6. Charles R. Shrader, The Muslim-Croat Civil War in Central Bosnia: A Military History, 1992-1994 (College Station: Texas A\&M University Press, 2003), 43-44.

7. Peter Andreas, "The Clandestine Political Economy of War and Peace in Bosnia," International Studies Quarterly 48, no. 1 (March 2004): 35-37.

8. See Richard Holbrooke, To End a War (New York: Random House, 1998), 72-73 (on the role of Croatian military success in American diplomacy and planning); and 164-67 (on the dynamics of American-led conversations between Presidents Tuđman and Izetbegović). Silber and Little argue that by 1995 "Croatia was the centerpiece of US strategy ... the counterbalance to Serbia ... with the might of international backing." Laura Silber and Allan Little, Yugoslavia: Death of a Nation (New York: Penguin, 1997), 361. 
9. Silber and Little, Yugoslavia, 383; Ivo H. Daalder, Getting to Dayton: The Making of America's Bosnia Policy (Washington, DC: Brookings, 2000), 181.

10. Valery Tishkov, Chechnya: Life in a War-Torn Society (Berkeley: University of California Press, 2004); see also Latinka Perović, "The Flight from Modernization," in The Road to War in Serbia: Trauma and Catharsis, ed. Nebojša Popov (New York: Central European University Press, 2000), 109-22.

11. Marcus Cox, State-Building and Post-Conflict Reconstruction: Lessons from Bosnia (Geneva: Centre for Applied Studies in International Negotiations, 2001).

12. See Richard Caplan, "International Authority and State Building: The Case of Bosnia and Herzegovina," Global Governance 10, no. 1 (2004): 62; Cox, State-Building, 19-20; and David Chandler, "From Dayton to Europe," International Peacekeeping 12, no. 3 (Autumn 2005): 336-49.

13. Bruno Waterfield, "Bloodshed to Return to Bosnia, Paddy Ashdown Fears," Telegraph, May 27, 2011, http://www.telegraph.co.uk/news/worldnews/europe/ serbia/8541578/Bloodshed-to-return-to-Bosnia-Paddy-Ashdown-fears.html.

14. "Commission Reports on Saudi Donations to Bosnia," Saudi Embassy, July 13, 2001, http://www.saudiembassy.net/archive/2001/news/page266. aspx. From 1992 to 2001, Saudi Arabia provided more than US\$380 million to Bosnia, in addition to providing further support for 10,000 orphans, for 3,000 Bosnian pilgrims, and for the restoration of over 160 mosques in the country.

15. Gerhard Spörl, "Opinion: Europe has no exit strategy for Bosnia," July 16, 2009, http://www.spiegel.de/international/europe/opinion-europe-has-no-exitstrategy-in-the-balkans-a-636347.html.

16. Steven R. Bowman, "Bosnia: U.S. Military Operations," in Congressional Research Service Issue Brief 93056. Estimates of the total costs of SFOR/IFOR from FY 1992 to FY 2002 came to over \$11 billion—while the US mission would continue for another three years, the size (and presumably the costs of US military operations) would decline considerably during that time.

17. Martina Fischer, "Introduction: Moving out of the Dayton Era into the Era of Brussels?" in Peacebuilding and Civil Society in Bosnia-Herzegovina, ed. Martina Fischer (London: Transaction, 2006), 12.

18. Zlatko Kovach, "World Bank Helps Tackle BiH’s Public Expenditures," SETimes.com, June 5, 2010, http://www.setimes.com/cocoon/setimes/xhtml/ en_GB/features/setimes/features/2010/05/06/feature-03.

19. Laza Kekic, "Aid to the Balkans: Addicts and Pushers," in Balkan Reconstruction, ed. Thanos Veremis and Daniel Daianu (London: Routledge, 2001), 24.

20. Sabrina P. Ramet, The Three Yugoslavias: State-Building and Legitimation, 1918-2005 (Bloomington: Indiana University Press, 2006), takes a remarkably positive view of Dodik's politics; while Bose, Bosnia after Dayton, 274, regards the Western international community's support of Dodik as a "sad story" of seeking "particular individuals" in preference to institutional reform and development. 
21. Thorsten Gromes, "The Prospect of European Integration and Conflict Transformation in Bosnia and Herzegovina," Journal of European Integration 31, no. 4 (July 2009): 438.

22. "Milorad Dodik-One Foot in Bosnia, but His Heart in Serbia," Radio Free Europe/Radio Liberty, April 28, 2009, http:/www.rferl.org/content/Milorad_Dodik_One_Foot_In_Bosnia_But_His_Heart_In_Serbia/1617635.html.

23. Many Bosnian Croats consistently have voted for the Croatian Democratic Union of Bosnia and Herzegovina/Hrvatska demokratska zajednica, or HDZ $\mathrm{BiH}$, which, similar to most of the Serb parties of Republika Srpska, has fought to maintain self-government and opposed reforms to centralize the state institutions of Bosnia. Florian Bieber, Post-War Bosnia: Ethnicity, Inequality and Public Sector Governance (London: Palgrave Macmillan, 2006), 62.

24. Tony Zinni and Tony Koltz, Leading the Charge: Leadership Lessons from the Battlefield to the Boardroom (New York: St. Martin's, 2009) , 210.

25. Carl Dahlman and Gearóid Ó.Tuathail, "The Legacy of Ethnic Cleansing: The International Community and the Returns Process in Post-Dayton BosniaHerzegovina," Political Geography 24, no. 5 (2005): 569-99.

26. One sign of the resurgence of religious belief is that while the numbers of atheists/nonreligious had grown from more than 12 percent to 31 percent of the population of the former Yugoslavia from 1953 to 1987, by 2006 only 2.5 percent of peoples throughout Yugoslavia classified themselves as such. In Bosnia the corresponding figures were 29 percent nonreligious by 1987, with only 5 percent nonreligious or atheist in 2000. Reinhard Henkel, "Religions and Religious Institutions in the Post-Yugoslav States between Secularization and Resurgence," Acta Universitatis Carolinae, nos. 1-2 (2009): 51, 53.

27. The roots of a moderate Islamization of Bosnian politics run deep, but grew especially strong during Bosnia's civil war, when, under the hammer blows of local Serbian atrocities, Bosnian Croatian ambivalence over a multinational polity, Western indifference, and significant support from the Muslim world, many Bosniaks, with the support and encouragement of President Alija Izetbegović, turned more and more to Islam as an answer to their sense of isolation during the war, as well as to fellow Muslims throughout the world, who often provided crucial aid during and after the war. Steven L. Burg and Paul S. Shoup, The War in BosniaHerzegovina: Ethnic Conflict and International Intervention (New York: M. E. Sharpe, 1999), 196-97. It should be noted that the separatist vision of the Islamic president Izetbegović, though at times supported, was contested (fiercely) by other devout Muslims whose understanding and practice of Bosnian Islam was much more inclusive and liberal. Rusmir Mahmutćehajić, The Denial of Bosnia, trans. Francis R. Jones and Marina Bowder (University Park: Pennsylvania State University Press, 2000), 43-44. See also Alison Pargeter, The New Frontiers of Jihad: Radical Islam in Europe (Philadelphia: University of Pennsylvania Press, 2008), 40-44, who notes the aid Iran and Saudi Arabia supplied to Bosniaks as well as the local resentment these countries' heavy-handed policies produced. 
28. Harun Karčić, "Islamic Revival in Post-Socialist Bosnia and Herzegovina: International Actors and Activities," Journal of Muslim Minority Affairs 30, no. 4 (2010): 525-32.

29. Ivan Iveković, "Nationalism and the Political Use and Abuse of Religion: The Politicization of Orthodoxy, Catholicism and Islam in Yugoslav Successor States," Social Compass 49, no. 4 (2002): 523-36. See also Dan Bilfelsky, "Islamic Revival Tests Bosnia's Secular Cast,” December 28, 2008, http://www.jonathantan.org/ handouts/Islam/Islam-H130aa-Bosnia.pdf; and Karčić's "Islamic Revival," noted above, for a discussion of the "desecularization" among Bosnian Muslims.

30. Eldar Sarajlić, "The Return of the Consuls: Islamic Networks and Foreign Policy Perspectives in Bosnia and Herzegovina" (paper presented at the conference "After the Wahabi Mirage: Islam, Politics and International Networks in the Balkans," European Studies Centre, University of Oxford, December 2010), 14-25.

31. Michael Sells, "Crosses of Blood: Sacred Space, Religion, and Violence in Bosnia-Hercegovina," Sociology of Religion 64, no. 3 (Autumn 2003): 309-31.

32. Juan A. Herrero Brasas, "In the Name of Mary: Sacred Space, Sacred Property, and Absolution of Past Sins," in Religion, Violence, Memory, and Place, ed. Oren Baruch Stier and J. Shawn Landres (Bloomington: Indiana University Press, 2006), 150-62.

Vjekoslav Perica argues that the influence of the "West Herzegovinian lobby" is so important throughout Croatia that "it is almost impossible to talk about the Croatian Catholic Right without mentioning the Franciscans of western Herzegovina." Perica, "The Most Catholic Country in Europe? Church, State, and Society in Contemporary Croatia," Religion, State, and Society 34, no. 4 (December 2006): 325.

33. Mirko Blagojevic, "Desecularization of Contemporary Serbian Society," Religion in Eastern Europe 28, no. 1 (February 2008): 37-50.

34. Janine Natalya Clark, "Religion and Reconciliation in Bosnia and Herzegovina: Are Religious Actors Doing Enough?” Europe-Asia Studies 62, no. 4 (June 2010): 671-94.

35. Clark notes numerous instances of how religious language has proved both powerful to devotees - such as the Muslim community's (both politicians and clergy) terming those Muslims who died during the war "šehidi/martyrs," or the insistence of Serbian clergy have cultivated a "victim" complex. Clark, "Religion and Reconciliation," 682.

36. Paddy Greer, "Bridge-Building in Mostar: From Fragmented Stumbling Blocks to Overarching Narrative Solutions," in Post-Conflict Reconstruction, ed. Neil Ferguson (Newcastle: Cambridge Scholars Publishing, 2010), 119-32.

37. John Kelsay, "Bosnia and the Muslim Critique of Modernity," in Religion and Justice in the War over Bosnia, ed. G. Scott Davis (New York: Routledge, 1996), 139.

38. Dzenita Mehic, "We Are Dying of Your Protection," Bulletin of the Atomic Scientists (March/April 1995): 44. 
39. Graham Timmins and Dejan Jović, "Introduction: The Next Wave of Enlargement; The European Union and Southeast Europe after 2004," Journal of Southern Europe and the Balkans 8, no. 1 (2006): 2-4.

40. R. Scott Appleby, The Ambivalence of the Sacred: Religion, Violence, and Reconciliation (New York: Carnegie, 2000), 3-8.

41. This view stands in stark contrast to our cooperation with much of the international community's postwar efforts to support ethnic cleansing throughout Europe to achieve the stability that we then believed only ethnically monolithic states could achieve. People throughout the former Yugoslavia were keenly aware of these contradictions, even as some of their number imposed ethnic cleansing upon their former fellow citizens. See Timothy Garton Ash, History of the Present: Essays, Sketches, and Dispatches from Europe in the 1990s (New York: Vintage Books, 1999), 191.

\section{REFERENCES}

Andreas, Peter. "The Clandestine Political Economy of War and Peace in Bosnia." International Studies Quarterly 48, no. 1 (March 2004): 29-51.

Appleby, R. Scott. The Ambivalence of the Sacred: Religion, Violence, and Reconciliation. New York: Carnegie, 2000.

Ash, Timothy Garton. History of the Present: Essays, Sketches, and Dispatches from Europe in the 1990s. New York: Vintage Books, 1999.

Bieber, Florian. Post-War Bosnia: Ethnicity, Inequality and Public Sector Governance. London: Palgrave Macmillan, 2006.

Bilfelsky, Dan. “Islamic Revival Tests Bosnia’s Secular Cast,” December 28, 2008. http:/www.jonathantan.org/handouts/Islam/Islam-H130aa-Bosnia.pdf.

Blagojevic, Mirko. "Desecularization of Contemporary Serbian Society." Religion in Eastern Europe 28, no. 1 (February 2008): 37-50.

Bose, Sumantra. Bosnia after Dayton: Nationalist Partition and International Intervention. New York: Oxford University Press, 2006.

Bowman, Steven R. "Bosnia: U.S. Military Operations." In Congressional Research Service Issue Brief 93056.

Brasas, Juan A. Herrero. "In the Name of Mary: Sacred Space, Sacred Property, and Absolution of Past Sins." In Religion, Violence, Memory, and Place, edited by Oren Baruch Stier and J. Shawn Landres, 150-62. Bloomington: Indiana University Press, 2006.

Burg, Steven L., and Paul S. Shoup. The War in Bosnia-Herzegovina: Ethnic Conflict and International Intervention. New York: M. E. Sharpe, 1999.

Caplan, Richard. "International Authority and State Building: The Case of Bosnia and Herzegovina." Global Governance 10, no. 1 (2004): 53-65.

Chandler, David. "From Dayton to Europe." International Peacekeeping 12, no. 3 (Autumn 2005): 336-49. 
Chollet, Derek. The Road to the Dayton Accords: A Study of American Statecraft. New York: Palgrave MacMillan, 2005.

Clark, Janine Natalya. "Religion and Reconciliation in Bosnia and Herzegovina: Are Religious Actors Doing Enough?” Europe-Asia Studies 62, no. 4 (June 2010): 671-94.

Cox, Marcus. State-Building and Post-Conflict Reconstruction: Lessons from Bosnia. Geneva: Centre for Applied Studies in International Negotiations, 2001.

Daalder, Ivo H. Getting to Dayton: The Making of America's Bosnia Policy. Washington, DC: Brookings, 2000.

Dahlman, Carl, and Gearóid Ó. Tuathail. "The Legacy of Ethnic Cleansing: The International Community and the Returns Process in Post-Dayton BosniaHerzegovina." Political Geography 24, no. 5 (2005): 569-99.

Fischer, Martina. "Introduction: Moving out of the Dayton Era into the Era of Brussels?" In Peacebuilding and Civil Society in Bosnia-Herzegovina, edited by Martina Fischer, 7-46. London: Transaction, 2006.

Greer, Paddy. "Bridge-Building in Mostar: From Fragmented Stumbling Blocks to Overarching Narrative Solutions." In Post-Conflict Reconstruction, edited by Neil Ferguson, 119-32. Newcastle: Cambridge Scholars Publishing, 2010.

Gromes, Thorsten. "The Prospect of European Integration and Conflict Transformation in Bosnia and Herzegovina." Journal of European Integration 31, no. 4 (July 2009): 431-47.

Henkel, Reinhard. "Religions and Religious Institutions in the Post-Yugoslav States between Secularization and Resurgence." Acta Universitatis Carolinae, nos. 1-2 (2009): 49-61.

Hoare, Marko Attila. How Bosnia Armed. London: Saqi Books, 2004.

Holbrooke, Richard. To End a War. New York: Random House, 1998.

Iveković, Ivan. "Nationalism and the Political Use and Abuse of Religion: The Politicization of Orthodoxy, Catholicism and Islam in Yugoslav Successor States." Social Compass 49, no. 4 (2002): 523-36.

Karčić, Harun. "Islamic Revival in Post-Socialist Bosnia and Herzegovina: International Actors and Activities." Journal of Muslim Minority Affairs 30, no. 4 (2010): 519-34.

Kekic, Laza. "Aid to the Balkans: Addicts and Pushers." In Balkan Reconstruction, edited by Thanos Veremis and Daniel Daianu, 20-40. London: Routledge, 2001.

Kelsay, John. "Bosnia and the Muslim Critique of Modernity." In Religion and Justice in the War over Bosnia, edited by G. Scott Davis, 117-42. New York: Routledge, 1996.

Knaus, Gerald, and Felix Martin. "Travails of the European Raj." Journal of Democracy 14, no. 3 (July 2003): 60-74.

Kovach, Zlatko. "World Bank Helps Tackle BiH's Public Expenditures." SETimes.com, June 5, 2010. http://www.setimes.com/cocoon/setimes/xhtml/ en_GB/features/setimes/features/2010/05/06/feature-03. 
Mahmutćehajić, Rusmir. The Denial of Bosnia. Translated by Francis R. Jones and Marina Bowder. University Park: Pennsylvania State University Press, 2000.

Mehic, Dzenita. "We Are Dying of Your Protection." Bulletin of the Atomic Scientists (March/April 1995): 41-44.

Pargeter, Alison. The New Frontiers of Jihad: Radical Islam in Europe. Philadelphia: University of Pennsylvania Press, 2008.

Perica, Vjekoslav. "The Most Catholic Country in Europe? Church, State, and Society in Contemporary Croatia." Religion, State, and Society 34, no. 4 (December 2006): 311-46.

Perović, Latinka. "The Flight from Modernization." In The Road to War in Serbia: Trauma and Catharsis, edited by Nebojša Popov, 109-22. New York: Central European University Press, 2000.

Radio Free Europe/Radio Liberty. "Milorad Dodik-One Foot in Bosnia, but His Heart in Serbia," April 28, 2009. http://www.rferl.org/content/Milorad_ Dodik_One_Foot_In_Bosnia_But_His_Heart_In_Serbia/1617635.html.

Ramet, Sabrina P. The Three Yugoslavias: State-Building and Legitimation, 19182005. Bloomington: Indiana University Press, 2006.

Sarajlić, Eldar. "The Return of the Consuls: Islamic Networks and Foreign Policy Perspectives in Bosnia and Herzegovina.” Paper presented at the conference "After the Wahabi Mirage: Islam, Politics and International Networks in the Balkans," European Studies Centre, University of Oxford, December 2010.

Saudi Embassy. "Commission Reports on Saudi Donations to Bosnia." July 13, 2001. http://www.saudiembassy.net/archive/2001/news/page266.aspx.

Sells, Michael. "Crosses of Blood: Sacred Space, Religion, and Violence in BosniaHercegovina." Sociology of Religion 64, no. 3 (Autumn 2003): 309-31.

Shrader, Charles R. The Muslim-Croat Civil War in Central Bosnia: A Military History, 1992-1994. College Station: Texas A\&M University Press, 2003.

Silber, Laura, and Allan Little. Yugoslavia: Death of a Nation. New York: Penguin, 1997.

Spiegel Online International. "Former European Commissioner Günter Verheugen: The EU 'Has No Vision of Where We Are Heading." February 9, 2010. http://www.spiegel.de/international/europe/0,1518,676784,00.html.

Timmins, Graham, and Dejan Jović. "Introduction: The Next Wave of Enlargement; The European Union and Southeast Europe after 2004.” Journal of Southern Europe and the Balkans 8, no. 1 (2006): 1-5.

Tishkov, Valery. Chechnya: Life in a War-Torn Society. Berkeley: University of California Press, 2004.

Waterfield, Bruno. "Bloodshed to Return to Bosnia, Paddy Ashdown Fears." Telegraph, May 27, 2011. http://www.telegraph.co.uk/news/worldnews/europe/ serbia/8541578/Bloodshed-to-return-to-Bosnia-Paddy-Ashdown-fears.html.

Zinni, Tony, and Tony Koltz. Leading the Charge: Leadership Lessons from the Battlefield to the Boardroom. New York: St. Martin's, 2009. 
PART II

Using Force? 



\section{CHAPTER 3}

\section{The Past and Future of Insurgency \\ Protracted Warfare and Protracted Counterinsurgency}

Jonathan M. House

\section{INTRODUCTION}

When Professor Miner invited me to this conference, he asked me to discuss the current debates and future possibilities for insurgency and counterinsurgency. In other words, I will try to focus on how such conflicts have worked in the past and may occur in the future; I'm sure the other panel members have a much better grasp of the issues that motivate such conflicts. Having said that, however, let me trespass for one minute into an area that I know is much more familiar to the other panelists than it is to me. My older daughter, having been an Army brat, was too smart to serve in uniform, so instead she joined the Foreign Service. Because the Department of State is as efficient as the Department of Defense in using its personnel correctly — which is to say, not very efficient at all—my daughter, who minored in Russian in college, spent six months learning Spanish before she was assigned to a consulate on the border between Mexico and Arizona. A year ago, she telephoned to tell us that she was getting hazardous duty pay, while living five blocks from the United States, because the drug wars had begun to target Americans.

My point is that insurgency has many forms and many different motives; it is not simply about takfiri terrorism or Marxism-Leninism, nor is it confined to the Middle East. The causes and methods of insurgency are almost timeless; only the tactics of combating it have changed in recent decades. 


\section{THEORY OF INSURGENCY}

Insurgency, or asymmetrical warfare, has existed throughout history. For example, the word "assassin" comes from the followers of Hasan-e Șabbāh (d. 1124), the head of a Persian sect of Shiites. Șabbāh sent out dedicated (and by some accounts drug-crazed, which may be the origin of the word "hashish") assassins in disguise to dispose of enemy leaders, allowing his independent sect to conduct its own foreign policy without a standing army.

Insurgency becomes most prominent, however, when one state or alliance has an overwhelming advantage in the conduct of conventional warfare, so that opponents feel they cannot possibly compete against the dominant army. This was true during the Napoleonic Wars, the post-World War II decolonization period, and it is true again today, when the United States and a few of its Westernized allies have developed such a lethal form of mechanized air-land combat that even large, well-equipped armies such as that of Iraq fall apart quickly.

Traditionally, insurgencies have functioned best as part of what my colleague Tom Huber has termed "Compound Warfare." The 1808-1814 conflict in the Iberian Peninsula was an illustration of this: Two forces, one conventional and one unconventional or insurgent, cooperated against a common enemy. In this instance, the conventional force was the relatively small British-Portuguese army commanded by Arthur Wellesley, the future Duke of Wellington, while the unconventional force was composed of various Spanish militias and other irregular forces, from which we get the modern term "guerrilla" for "little war." Napoleon's imperial armies were what would today be labeled the counterinsurgent force. To control the guerrillas, the French needed to disperse throughout the peninsula, whereas to defeat Wellington, they needed to concentrate their troops in one mass. ${ }^{1}$ Although they outnumbered their opponents by as much as five to one, the French were unable to do both, and failed accordingly. There are numerous similar examples of compound warfare, such as the British forces in Palestine with T. E. Lawrence's Arabs against the Turks in 1918, and the Continental army and irregulars like Francis Marion during the American Revolution.

Notice, however, that such a compound approach tends to relegate the insurgent or guerrilla to a supporting role; it is possible for observers and historians to even overlook that role completely and assume that the conventional army won by itself. This is one reason why Western armies have tended to dismiss insurgents as relatively unimportant.

Mao Tse-tung had several original ideas in his life, but for our purposes his most important one was the idea that the insurgent or guerrilla could "grow his own" armies, develop his own force that was capable of defeating its 
opponent using tactics that resembled those of a conventional army. This is in effect what the Chinese Communists did during the final, post-1945 phase of their civil war, defeating the huge, well-equipped nationalist forces of Chiang Kai-shek.

I should hasten to add two points about Mao's theory, however: First, the essence of his insurgency was that it was protracted, a long, drawn-out struggle that wore down the capabilities and motivation of the insurgent's opponents. Quick victory through insurgency is an oxymoron, as Che Guevara discovered so painfully in Bolivia, and as the Greek Communists learned when they tried to create a conventional army and government during the 1946-1949 civil war. Second, many insurgencies that appeared to fit Mao's model were in fact instances of compound warfare. Most famously, the Vietcong suffered heavily during and after the 1968 Tet offensive, so that by some revisionist accounts the United States and South Vietnam eliminated the VC structure in many areas of Vietnam. ${ }^{2}$ Although the protracted insurgency in Vietnam undoubtedly succeeded in causing the US to leave the country, victory still required that the North Vietnamese army, a superbly equipped mechanized force, conduct two major conventional campaigns in 1972 and 1975 before it defeated its southern opponents. As James Willbanks, my boss, refers to his participation as an adviser in the first of these campaigns, "Willbanks' First Law is that, if they're using tanks, they're not guerrillas." One could argue, of course, that these tanks represent the logical conclusion of Mao's desire for the insurgent to grow his own forces. However, even if you consider the two different states of Vietnam to be one nation, the mechanized forces of the North Vietnamese army did not arise from the Vietcong but were the sons and grandsons of the Vietminh in the first conflict.

Let me return for a moment to Mao, who in 1930 gave us the most famous prescription for guerrilla warfare:

Divide our forces to arouse the masses, concentrate our forces to deal with the enemy.

The enemy advances, we retreat; the enemy camps, we harass; the enemy tires, we attack; the enemy retreats, we pursue.

To extend stable base areas, employ the policy of advancing in waves; when pursued by a powerful enemy, employ the policy of circling around.

Arouse the largest number of the masses in the shortest possible time and by the best possible methods. ${ }^{3}$

Put simply, this means that an insurgent attacks his opponent only when he can achieve a temporary superiority of forces at the precise point of battle or 
ambush; otherwise, the guerrilla must avoid battle in order to survive. This is why Western commentators are so fascinated with the passage that begins "The enemy advances, we retreat." Notice, however, that Mao's tactical advice is preceded and followed by a constant emphasis on the need to motivate and mobilize the populace. For Mao and for most successful insurgents, gaining and maintaining political support is far more important than what happens on the battlefield. Carl von Clausewitz may have taught Mao that "war is merely the continuation of policy by other means," ${ }^{\text {"4 }}$ but the Chinese leader took this idea to its extreme, insisting that politics and popular motivation were at the center of any struggle. For example, one of Mao's most effective weapons was his literacy program, teaching peasants to read so that they could better absorb Communist ideology. This has an interesting parallel in Saudi Arabia, where the dominant Wahhabi sect controls primary education to spread its interpretation of Islam, thereby producing most of the $9 / 11$ hijackers.

Mao, as I've already remarked, did not believe that insurgency must or would always use guerrilla tactics. In fact, he condemned those of his colleagues who focused on "guerrilla-ism" rather than adjusting their methods to local circumstances. Thus, "guerrilla" is only one methodology or set of tactics to be used in protracted asymmetrical warfare-depending on the circumstances, terror bombings, labor strikes, and large public protests may all be used as means to the end of wearing down and replacing the existing counterinsurgent government. For an example of this, look at the left wing in Cuba from the 1930s through 1958, which laid the foundation for Fidel Castro's guerrilla success at the end of this period.

\section{COUNTERINSURGENCY THEORIES}

If insurgency (or protracted revolutionary warfare) has existed for millennia, how did governments go about repressing such insurgencies? In the vast majority of cases, rulers regarded the insurgents as malcontents, troublemakers, and criminals who should be put down as quickly and violently as possible. Rebels would be executed either with or without trial, depending on local norms. The measure of effectiveness for such a counterinsurgency was often the body count, the number of rebels (whether real or imaginary) killed or at least imprisoned. Colonel Gadhafi obviously believed in this approach.

Truly ruthless governments may, in fact, eliminate all effective opposition and thereby restore their control, at least in the short run. No one successfully rebelled against Joseph Stalin, for example, although the Lithuanians, Ukrainians, and other non-Russian groups certainly tried at the end of World War II. ${ }^{5}$ 
From our current perspective, however, there are numerous problems with this approach, which is focused on eliminating the full-time insurgents. Quite apart from the immorality of attempting to kill large groups without adequate trial, such repression may actually increase the resentment and resistance to the ruling regime, so that killing ten insurgents actually leaves you with one hundred new insurgents to face-this is known as "Afghan math." As early as Cyrus the Great in the sixth century BC, rulers found that it was much easier to conquer and govern people by tolerating local cultures and customs than by forcing them to conform to central standards.

When the rebellion was obviously violent or extreme, of course, there was usually no question about the right and necessity of repression. However, if the resistance took the form of large, relatively peaceful and prosperous crowds, the troops involved might refuse to fire, and in fact might go over to the rebel side. This happened on numerous occasions in European history, most notably in Paris in 1789, 1830, and 1848 ; $^{6}$ it apparently happened again in 2011 in Egypt, although we don't know all the details yet.

Moreover, what about the case when the government itself regarded the rebels as simply misguided citizens? Consider, for example, the long and patient efforts of the British government to deal with the American colonists during the 1760s and 1770s. Even after the skirmishes at Lexington and Concord had converted the confrontation into a rebellion, Sir Henry Clinton, the British commander in New England, wrote that he needed "to gain the hearts and subdue the minds of America." 7

To further complicate matters, what happened when the counterinsurgent force was from a foreign country, thereby giving the insurgent easy propaganda victories such as labeling the third party as a colonialist and the existing government as a puppet? In Afghanistan, for example, the United States and its NATO allies have attempted to enforce what we consider to be universal values, such as equality for women and suppression of the drug trade based on poppy cultivation. As Ralph Peters has noted, this makes the Westerners into the revolutionaries, upsetting the social and economic norms of the population in question. Such actions can well give rise to what David Kilcullen has termed "the Accidental Guerrilla," the man fighting not for some abstract revolutionary cause but rather to defend his locality and way of life. ${ }^{8}$ Kilcullen argues convincingly that our true enemies, such as al-Qaeda, can provoke us into such situations, which only contribute to the insurgent's ability to wear out the counterinsurgent while politically weakening the already-fragile state in question. Meanwhile, the guerrilla uses the local culture as part of his camouflage, with the foreign troops on the outside trying to pierce that camouflage. 
Therefore, instead of viewing insurgencies as simply rebels vs. government or patriots vs. repressors, the most common recent view of this problem is what John Shy once called "the triangularity of the struggle." This viewpoint assumes that there are three actors in any insurgency: a minority of people who actively support the insurgency, another minority of people who actively support the existing regime and its counterinsurgent effort, and a large group of people - often the majority of the population-who are generally neutral. This majority undoubtedly has opinions about the issues at stake, but is more concerned with its own livelihood and security from attack. ${ }^{10}$ Shy argued that in the American Revolution, for example, the British ultimately lost because they could not protect the populace from Patriot irregulars, leaving that populace no choice but to acquiesce with the revolutionaries. In fact, Shy noted that the rebels used the mechanism of local government to force everyone to join the local Patriot militia. Neutrality became impossible, and the minority of British Loyalists had to move to other British colonies.

This triangular interpretation is behind the now-common theory of population-centric, rather than enemy force-centric, counterinsurgency. Here, the counterinsurgent forces seek to gain the trust and support of the population, not only protecting the people from attack and trying to separate the insurgents from the populace but, where necessary, addressing local needs such as water, sanitation, schools, and so on. One obvious drawback of this approach, of course, is that it never produces the kind of overnight success that Western societies expect from their militaries. In fact, it is difficult if not impossible to develop objective measurements of the degree of success, if any, that the counterinsurgent forces are having in gaining popular support. ${ }^{11}$ However, given the protracted nature of most insurgencies, the counterinsurgent force might as well try to accomplish something positive while waiting for the insurgent to fail or lose hope. Another aspect is that the counterinsurgent must always try to use minimum force, like a policeman, while the insurgent has no such limits on violence. ${ }^{12}$ Any deadly force, however necessary, may cause civilian casualties or otherwise alienate the population the counterinsurgent seeks to attract. This is particularly difficult for conventional armed forces, which are designed to deliver maximum rather than minimum force.

The actual winner in any insurgency depends on many factors. First and foremost, as already suggested, is the legitimacy of the government and the degree to which the populace recognizes that government as legal and binding. This, of course, is at the heart of this conference's focus on "failed states." To draw an obvious conclusion about the two conflicts in Vietnam, for example, much of the populace rightly or wrongly considered the French and the South Vietnamese governments to be foreign and unrepresentative. No amount of 
military skill in the field can overcome such a perception, as it saps the will of the populace, as well as of any third-party nation, such as the United States, that is involved in the counterinsurgency. In Vietnam, American efforts to avoid the image of foreign colonialism only handicapped our efforts without convincing the local populace. You may recall that the senior American headquarters in that struggle was called the "U.S. Military Assistance Command, Vietnam" - we maintained the fiction that we were only "assisting" the army of the Republic of Vietnam, and thus never achieved unity of command and effort.

Another consideration, which we tend to overlook, is geography. Terrain that is difficult to move through-mountains, forests, swamps, junglesusually favors the insurgent, who can more easily attack and retreat as necessary. Such terrain also drives up the cost of counterinsurgency, because the only way the security forces can get at the insurgents is by means of very expansive hardware such as helicopters and aircraft. More importantly, however, one has to look at the borders of the country under attack. Every insurgent needs access to another country, preferably a friendly one, which provides sanctuary, weapons, supplies, and so on. In both of the Indo-Chinese conflicts (that is, 1946-1954 and 1959-1975), the North Vietnamese Communists had ready access to Chinese sanctuary, aid, and advice; in the second conflict, the North used the neutral countries of Laos and Cambodia to funnel troops and weapons into South Vietnam. If, on the other hand, the insurgency is isolated on islands (such as the Philippines) or a peninsula (Malaya and Greece), or even by artificial structures such as elaborate border fortifications (Algeria), the insurgent will be much more vulnerable to being cut off and defeated.

Then there are the nonmilitary factors. Unemployment and poverty favor an insurgent and make it difficult for the government to assist the populace. Generally speaking, a successful counterinsurgency will involve the united efforts of all the government's agencies and all its levers of power-political/ diplomatic, information, military, and economic.

\section{FUTURE WARFARE}

With this brief background, let me leave the comfortable realm of the historian and attempt to make observations about future warfare. Still, history is the only source, however imperfect, of data from which to generalize, so bear with me. ${ }^{13}$

We should recognize that future wars will not necessarily be insurgencies or asymmetrical contests like those of the past decade. I would submit that this is true for two reasons: First, nation-states remain strong, and there is 
always the possibility of another conventional force-on-force conflict. I am not one of those who claim that we will have a military collision with China, but neither can we exclude unexpected conflicts, such as the Falklands or Malvinas War of 1982 or the Russian-Georgian conflict in 2009. As Defense Secretary Robert Gates remarked in a 2011 speech, "when it comes to predicting the nature and location of our next military engagements, since Vietnam, our record has been perfect. We have never once gotten it right, from the Mayaguez to Grenada, Panama, Somalia, the Balkans, Haiti, Kuwait, Iraq, and more-we had no idea a year before any of these missions that we would be so engaged." 14

Moreover, the very fact that Western forces are today preoccupied with counterinsurgency means that such forces neglect the conventional skills that gave them military dominance. Because training time and funds are limited, soldiers can't master every possible form of warfare. To cite but one example, during the early years of this century, the Israel Defense Forces had to dedicate all their troops to security and counterinsurgency against radical Palestinians in the West Bank and Gaza. The IDF had little time to practice the armorheavy combat that had made it famous. This is one of the principal reasons for Israel's defeat by Hezbollah in 2006. This risk is particularly great if the insurgent is able to combine conventional and unconventional weapons and tactics. Such a combination is usually called "hybrid warfare," although it is largely a variant of the compound warfare I mentioned earlier. ${ }^{15}$

Still, it is a safe bet that asymmetrical warfare will remain a major form of conflict in the foreseeable future. If anything, such tactics are easier to apply in the twenty-first century than in the nineteenth or twentieth century because of improved technology. For example, the classic problem for revolutionaries was to minimize the effects of one rebel being captured or converted by the government. The usual method to limit the damage was to organize small cells, consisting of only three people, so that one person could possibly betray the names of only the other two people in his or her cell, plus one more person located in an adjacent cell. This was the structure of bomb-makers in Algiers in 1957, when the French army used months of investigation and frequent torture to trace the members of all the cells and put the terrorists out of action. ${ }^{16}$ In 1965, however, science-fiction author Robert Heinlein correctly predicted that a computer network would enable revolutionaries to contact innumerable fellow conspirators without ever meeting or even knowing the identities of those conspirators. ${ }^{17}$ The advent of the Internet, Facebook, cell phones, and other electronic devices makes insurgency much easier, and counterinsurgency more difficult, than it was fifty years ago. The unsuccessful efforts of the Egyptian and Iranian governments to deny Internet service show 
how difficult it is for any state to control the flow of information as it might have done years ago.

Moreover, insurgencies no longer need to complete their rebellions in a hail of gunfire and an armed march on the capital. Particularly when dealing with weak states, the insurgent may well be able to co-opt the government from within. Hezbollah has clearly done this in Lebanon, combining its reputation as an opponent of Israel with large social welfare programs and a major political party. Hamas attempted to do the same thing in the Gaza Strip, culminating in its 2007 takeover of the Strip from the Palestine Liberation Front; unfortunately for the people of Gaza, Hamas is stuck on the horns of a dilemma because it has pledged never to recognize Israel or cede Arab land, and without such recognition its rule has only led to more misery.

The Mexican drug conspiracies, like the Taliban in Pakistan, represent a variation on this theme. Traditionally, we have assumed that an insurgent sought to take over control of the entire state, but what happens if a nonstate actor is satisfied with controlling a particular border region? Although one can hardly categorize Mexico or Pakistan as a "failed state," in each case the nonstate actors have challenged the central government's exclusive control of force in specific areas. Perhaps the breakaway regions of Abkhazia and Ossetia have accomplished the same thing in Georgia, although there the conventional force of Russia is far more significant than any local insurgency.

Both of these approaches-co-opting from within, like Hezbollah; and gaining control of a limited region within a larger state-complicate the efforts not only of the state being attacked, but also of third parties such as the United States who are willing to help counter the insurgency. It is already difficult politically for a sovereign state to ask for foreign assistance against a classic internal insurgency, but even more embarrassing to admit that one can't maintain order in some small area along one's own border. Thus, no matter how many drones the US may employ on the Pakistani border, Islamabad simply cannot invite the US in to help police the border regions in question. Nor, given our troubled history, can Mexico City ask for US troops.

To come back to the overall future of insurgency: Insurgencies are fundamentally about extreme public dissatisfaction with the existing regime or, perhaps in the case of nonstate actors such as al-Qaeda, dissatisfaction with an entire group of regimes. The demonstrations and violence that occurred in the winter of 2010-2011 reflect massive economic and political unrest quite apart from the cultural clashes of Western society with the rest of the world. Even in cases such as Tunisia and Egypt, where the ruling regimes collapsed quickly, their successors will be hard-pressed to satisfy public demands for change. We appear to be entering another era like that of the late 1950s and early 1960s, 
when large colonial empires dissolved quickly and the newly independent people expected major changes to occur overnight. This so-called "Revolution of Rising Expectations" meant that no government or economy, however successful, could keep up with public illusions about what was possible. Add increasing worldwide scarcity in grain and fuels, and you have a witches' brew of frustration. This situation is rife with the possibilities for armed conflict and perhaps insurgency.

With that as background, let me conclude by listing some of the factors that can facilitate efforts to counter and control future insurgencies:

First and foremost, as I already noted, is the need for the existing state to be functioning and legitimate. One can argue that no state can do this without first establishing a secure environment, but the reverse is also true-a secure environment means nothing if the majority of the population does not perceive the government as legitimate.

Second, and closely related, is the need for that government to understand and address the needs of the people, including the issues (real or invented) on which the insurgents are building. Especially when foreign troops such as Americans become involved in counterinsurgency, those foreign troops must both understand the culture and issues with which they are dealing and make every effort to have the host nation's forces appear to be in charge and effective.

Third, it is important to recognize the insurgency as such at the earliest possible point in time. Some of you undoubtedly recall the Bush administration's repeated refusal to admit that there was an insurgency in Iraq during 2004 and 2005. This is natural, because governments prefer to regard any rebels as criminals, without dignifying the insurgents' political cause by discussing it publicly. However, as long as the existing government insists that it's dealing with only criminals, then all the peacetime constraints about minimum force, probable cause, sufficient evidence, and so on apply to efforts to control those "criminals."

It is also important to avoid assuming that all your opponents have the same goals. Particularly in weak or failed states, there may well be multiple different groups of insurgents with different agendas. By lumping them all under a simple label such as "jihadists," the counterinsurgents not only fail to understand their motivations but also miss opportunities to form alliances with some groups against others.

Fourth, the full-time insurgents must be isolated from outside help and, as far as possible, from the support of the populace. So long as the insurgents can easily cross and recross borders while gaining information, recruits, and supplies from the populace, the counterinsurgents will have great difficulty repressing the uprising. 
Fifth, while local paramilitary police and infantry troops are essential to provide government presence throughout the country, these "boots on the ground" cannot sustain themselves without a structure for recruiting, paying, training, and supplying those forces in the field. In Vietnam, Iraq, and now Afghanistan, the United States has found it much easier to build infantry battalions than a durable logistics support structure.

Finally, the counterinsurgency effort has to be sustainable both economically and psychologically. As I noted earlier, the essence of an insurgency is to wear down the security forces both physically and mentally. Insurgents who are motivated by their religious beliefs in an afterlife are particularly suited to such a protracted, attritional conflict. In order to win, not only the troops involved but the nation or nations providing those troops must recognize that insurgency is often measured in decades, not months. As Henry Kissinger observed about the United States in Vietnam, "In the process, we lost sight of one of the cardinal maxims of guerrilla war: the guerrilla wins if he does not lose. The conventional army loses if it does not win." 18

\section{NOTES}

1. See Thomas M. Huber, ed., Compound Warfare: That Fatal Knot (Fort Leavenworth, KS: U.S. Army Command and General Staff College Press, 2002), esp. 91-112.

2. Dale Andrade and James H. Willbanks, "CORDS/Phoenix: Counterinsurgency Lessons from Vietnam for the Future," Military Review 86, no. 2 (March-April 2006): 9-23.

3. Mao Tse-tung, Selected Military Writings of Mao Tse-tung (Peking: Foreign Language Press, 1972), 72, emphasis added.

4. Carl von Clausewitz, On War, bk. 1, ed. and trans. Michael Howard and Peter Paret (Princeton, NJ: Princeton University Press, 1976), 87.

5. Crane Brinton, The Anatomy of Revolution, rev. ed. (New York: Vintage Books, 1965), 174-75. For an example of the effects of Soviet counterinsurgency, see Darius Bernotas, "Lithuanian Freedom Fighters' Tactics Resisting the Soviet Occupation, 1944-1953" (master's thesis, U.S. Army Command and General Staff College, 2012).

6. Jonathan M. House, "Controlling Revolutionary Paris, 1789-1848," in The Consortium on Revolutionary Europe, 1750-1850: Proceedings, 1989, ed. Donald C. Horward and John C. Horgan (Tallahassee: Florida State University, 1990), 661-69.

7. Clinton memorandum, February 1776, quoted in Stephen Conway, "To Subdue America: British Army Officers and the Conduct of the Revolutionary War," William and Mary Quarterly 43, no. 3 (July 1986): 381. 
8. David Kilcullen, The Accidental Guerrilla: Fighting Small Wars in the Midst of a Big One (Oxford: Oxford University Press, 2009), 28-32.

9. John Shy, "The American Revolution: The Military Conflict Considered as a Revolutionary War," in Essays on the American Revolution, ed. Stephen G. Kurtz and James H. Hutson (Chapel Hill: University of North Carolina Press, 1973), 121-56.

10. See also David Galula, Counterinsurgency Warfare: Theory and Practice (Westport, CT: Praeger Security, 2006), 55.

11. See Gregory A. Daddis, No Sure Victory: Measuring U.S. Army Effectiveness and Progress in the Vietnam War (Oxford: Oxford University Press, 2011).

12. See, for example, U.S. Army and U.S. Marine Corps, Counterinsurgency, Field Manual 3-24 (Washington, DC: Department of the Army, 2006), 1-21 to 1-29.

13. See Colin S. Gray on the dangers of predicting the future of war: "Been There! Done That! Blood in the Crystal Ball," Historically Speaking 7, no. 3 (JanuaryFebruary 2006): 25-28.

14. Robert M. Gates, speech, U.S. Military Academy, February 25, 2011, quoted at http://www.dennismansfield.com/business/2011/02/sec-robert-gatesaddress-to-west-point-today-february-25th-2011.html.

15. "Hybrid warfare" has many definitions, but see Kilcullen, Accidental Guerrilla, 148-51.

16. Roger Trinquier, Modern Warfare: A French View of Counterinsurgency, trans. Daniel Lee (London: Pall Mall Press, 1964), 10-15; see also Paul Aussaresses, The Battle of the Casbah: Terrorism and Counter-Terrorism in Algeria, 19551957, trans. Robert L. Miller (New York: Enigma Books, 2002).

17. Robert A. Heinlein, The Moon Is a Harsh Mistress (New York: Berkley, 1966). The novel originally appeared as a magazine serial in 1965.

18. Henry A. Kissinger, "The Viet Nam Negotiations," Foreign Affairs 47, no. 2 (January 1969): 214.

\section{REFERENCES}

Andrade, Dale, and James H. Willbanks. "CORDS/Phoenix: Counterinsurgency Lessons from Vietnam for the Future.” Military Review 86, no. 2 (March-April 2006): 9-23.

Aussaresses, Paul. The Battle of the Casbah: Terrorism and Counter-Terrorism in Algeria, 1955-1957. Translated by Robert L. Miller. New York: Enigma Books, 2002.

Bernotas, Darius. "Lithuanian Freedom Fighters' Tactics Resisting the Soviet Occupation, 1944-1953." Master's thesis, U.S. Army Command and General Staff College, 2012.

Brinton, Crane. The Anatomy of Revolution. Rev. ed. New York: Vintage Books, 1965. 
Clausewitz, Carl von. On War. Bk. 1. Edited and translated by Michael Howard and Peter Paret. Princeton, NJ: Princeton University Press, 1976.

Conway, Stephen. "To Subdue America: British Army Officers and the Conduct of the Revolutionary War." William and Mary Quarterly 43, no. 3 (July 1986): 381-407.

Daddis, Gregory A. No Sure Victory: Measuring U.S. Army Effectiveness and Progress in the Vietnam War. Oxford: Oxford University Press, 2011.

Galula, David. Counterinsurgency Warfare: Theory and Practice. Westport, CT: Praeger Security, 2006.

Gates, Robert M. Speech, U.S. Military Academy, 25 February 2011. http://www. dennismansfield.com/business/2011/02/sec-robert-gates-address-to-westpoint-today-february-25th-2011.html

Gray, Colin S. "Been There! Done That! Blood in the Crystal Ball." Historically Speaking 7, no. 3 (January-February 2006): 25-28.

Heinlein, Robert A. The Moon Is a Harsh Mistress. New York: Berkley, 1966.

Huber, Thomas M., ed. Compound Warfare: That Fatal Knot. Fort Leavenworth, KS: U.S. Army Command and General Staff College Press, 2002.

Kilcullen, David. The Accidental Guerrilla: Fighting Small Wars in the Midst of a Big One. Oxford: Oxford University Press, 2009.

Kissinger, Henry A. "The Viet Nam Negotiations," Foreign Affairs 47, no. 2 (January 1969): 211-34.

Mao Tse-tung. Selected Military Writings of Mao Tse-tung. Peking: Foreign Language Press, 1972.

Shy, John. "The American Revolution: The Military Conflict Considered as a Revolutionary War." In Essays on the American Revolution, edited by Stephen G. Kurtz and James H. Hutson, 121-56. Chapel Hill: University of North Carolina Press, 1973.

Trinquier, Roger. Modern Warfare: A French View of Counterinsurgency. Translated by Daniel Lee. London: Pall Mall Press, 1964.

U.S. Army and U.S. Marine Corps. Counterinsurgency. Field Manual 3-24. Washington, DC: Department of the Army, 2006. 


\title{
CHAPTER 4
}

\section{"The Lessons of the Last War Are Clear" \\ The Military-Industrial Complex, Private Contractors, and US Foreign Policy}

\author{
James M. Carter
}

The recent conflict has demonstrated more convincingly than ever before the strength our nation can best derive from the integration of all of our national resources in time of war. It is of the utmost importance that the lessons of this experience be not forgotten in the peacetime planning and training of the Army. The future security of the nation demands that all those civilian resources. . . be associated closely with the activities of the Army in time of peace.

—Dwight D. Eisenhower, April 27, 1946

This conjunction of an immense military establishment and a large arms industry is new in the American experience. The total influenceeconomic, political, even spiritual - is felt in every city, every State house, every office of the Federal government. We recognize the imperative need for this development. Yet we must not fail to comprehend its grave implications. Our toil, resources and livelihood are all involved; so is the very structure of our society.

In the councils of government, we must guard against the acquisition of unwarranted influence, whether sought or unsought, by the militaryindustrial complex. The potential for the disastrous rise of misplaced power exists and will persist.

—Dwight D. Eisenhower, Farewell Address, January 17, 1961 
It may well be that the lessons of the last war are always clear. The problem is that those lessons are often much more obviously useful for the last war, and not necessarily for those to come. When General Eisenhower drew on World War II as "the last war" for its lessons, he believed the war had been won in large part through total mobilization and the use of the private sector. Going forward, then, he viewed the integration of various public, academic, scientific, military, and political resources as vital to the nation's foreign policy, national security, and, ultimately, its wars. Over the next decade and a half, those resources were indeed integrated as the nation prepared and launched a cold war. So thorough had been this integration that Eisenhower famously warned the nation in his 1961 Farewell Address of a "military-industrial complex," and of "the potential for the disastrous rise of misplaced power" that had accompanied that integration.

At the end of the Cold War more than four decades later, that integration had expanded dramatically. Much of what the former Republican president warned against not only had come to pass, but either was not recognized as threatening to the nation's ideals and democratic institutions or was embraced as part of a pervasive "new American militarism" according to some, including military historian Andrew Bacevich. ${ }^{1}$ To be sure, a reliance on private corporations is not of recent vintage. During the Vietnam War, as this essay will make clear, the United States turned over to a private consortium responsibility for nearly all construction projects designed to make a large-scale war possible. On their own terms, they succeeded, and many termed what they accomplished "the construction miracle of the decade," despite a tragic and failed war. In any case, most of us take for granted that the United States now conducts foreign policy interventions, occupations, wars, and nation-building campaigns relying to a large extent on the private sector. The increased role of private corporations, even the "privatization of the military," is fraught with problems-problems of war profiteering and corruption, problems of accountability and transparency. Since the end of the Cold War in 1991, the phenomenon has grown exponentially. This essay will explore these changes by viewing the corporate roles in both Iraq and Vietnam and will attempt to deal with some of their implications for the future of US foreign policy.

\section{THE END OF THE COLD WAR AND THE "LAST SUPPER"}

In 1993, the administration of Bill Clinton, and specifically his secretary of defense, Les Aspin, organized a gathering of about fifteen CEOs from the leading military contractors for dinner at the Pentagon. One of those present 
at the dinner was Norman Augustine, then head of Martin Marietta. He later recounted part of the evening, saying, "At the dinner, I was seated next to the defense secretary, and we discussed what appeared to be the industry's evolving strategy for survival — a strategy which I referred to as Mutual Assured Starvation," a scenario in which multiple companies compete to build the pieces of one airplane-rather than those companies each building multiple airplanes. ${ }^{2}$ Augustine understood that budgets would be shrinking and, of course, that meant fewer and fewer orders for contractors.

As it turned out, however, that's not what the secretary had in mind that evening. Indeed, the administration's plans for the future of the leading Pentagon contractors were much more far-reaching. Aspin told his audience, in no uncertain terms, that they would have to either merge or die. Contractors grown fat on the swollen budgets of the Reagan military buildup during the 1980s would now have to learn to make do with less. The Pentagon needed fewer contractors, and those gathered would be responsible for getting the industry in line with a new economic landscape. The Pentagon would, in part, subsidize the transition by taking care of the costs of dismantling factories, moving parts and equipment and so on. ${ }^{3}$ The resulting wave of mergers and acquisitions that followed is well known: "The rest is history," Augustine later wrote. "General Electric Aerospace merged with Martin Marietta, which combined with Lockheed. McDonnell Douglas joined Boeing. Grumman joined Northrop. When the dust had cleared, there were only a few firms left standing." Those remaining, five actually, are often referred to as the "primes," and include Lockheed Martin, General Dynamics, Ratheon, Northop-Grumman, and Boeing.4 They are just one, albeit large, exponent of the modern military-industrial complex. Little did the so-called primes realize how drastically this private-government relationship would expand over the next decade.

Around the same time, Dick Cheney boasted about the omnipresence of his former company, Brown and Root, in the conduct of US foreign policy, saying, "The first person to greet our soldiers as they arrive in the Balkans and the last one to wave good-bye is one of our employees." Although speaking specifically about the firm's role in the Balkans crisis of the 1990s, Cheney's comment reflected a larger phenomenon that has grown exponentially over the years since. That phenomenon is the United States government's reliance upon private corporations to meet its foreign policy objectives. Today, hundreds of private corporations operate under contract with the government to provide services too numerous to count. Their presence mushroomed in the years following the end of the Cold War. Now, hundreds of companies compete for federal contracts supporting the US military operations around 
the world. From 1994 to 2002, the US government signed more than three thousand contracts worth an estimated $\$ 300$ billion with private firms. ${ }^{6}$

Many more corporations than most Americans realize are now tied to the conduct of US foreign policy in complex ways. They are no longer merely called upon by the state for support during war; nor are they simply producing this or that weapon system for the Pentagon. They are increasingly present in the absence of war in the everyday functioning of the US military worldwide and carry out many tasks that were once the responsibility of uniformed personnel. At the same time, these companies have become ensconced in political terms as well. In addition to extensive lobbying efforts, companies skillfully establish a production presence in as many states across the nation as possible, and thus have effective political leverage in the Congress through elected officials who will move to protect the jobs these companies create. That political insulation is parlayed into increasing legislative favors, Pentagon and State Department contracts, access to power, and a more influential voice in the country's foreign affairs generally. This access and influence are perhaps nowhere more visible than in the invasion and occupation of Iraq beginning in 2003.

\section{"A PARADE OF HORRIBLES": PRIVATE CONTRACTORS AND THE RECONSTRUCTION OF IRAQ}

In September 2001, then secretary of defense Donald Rumsfeld initiated a review of existing Iraq War plans and ordered that the new plans not include any preparations for administering Iraq after the removal of Saddam Hussein. Shortly thereafter, in early 2002, the State Department initiated its own study to deal specifically with postwar requirements of an Iraqi state with no government. By August 2002, the National Security Council also had initiated its own internal study. Around the same time, interagency groups involved in the planning included the CIA; the US Agency for International Development (USAID); the Joint Chiefs of Staff; and the Defense, Treasury, Justice and Commerce Departments. Despite what might appear to be a lot of serious planning and preparations for the massive reconstruction needs of a postinvasion Iraq, the reverse was the case. The various agency and interagency groups worked instead on their own corner of the problem as they saw it. None really knew what the others were doing. Indeed, "all the interagency Iraq planning groups were working in secret. Few knew the others existed," according to the report. ${ }^{7}$

State and Defense each produced dark scenarios-a list of 29 from Defense included at number 13 "not finding WMD" - termed a "Parade of Horribles" and "The Perfect Storm," for what might go wrong in Iraq, and yet neither 
shared these assessments with the others. As planning proceeded, systematic study and policy formation around reconstruction needs were shunted aside by Rumsfeld and Defense as the administration tightly focused on the military task of toppling Saddam Hussein. Before the end of the year, President Bush assigned the Defense Department total responsibility for postinvasion Iraq. In making the decision, the president had sidestepped the existing internal system - those numerous interagency working groups toiling away for months crafting plans to stabilize Iraq-in favor of Defense and Rumsfeld's own inhouse working groups. Those working outside the Department of Defense couldn't believe what had just happened—one USAID official recalled, "We were just stunned." The point of all this is to demonstrate the unconscionable lack of coordination and policy integration amid which the United States invaded Iraq. ${ }^{8}$

Following the rapid American invasion and conquest of Iraq in March 2003, postwar planners and experts were quickly flown into neighboring countries to wait for the dust to settle before entering Baghdad to begin their work in stabilizing and rebuilding a ravaged country. Within weeks, the federal government began granting contracts to American corporations to rebuild Iraq's infrastructure. According to the Center for Public Integrity's investigation, those with the best relationship to government officials quickly found themselves on an inside track with greater access to the enormous sums of money pouring into Iraq. As of September 2003, Vice President Dick Cheney's old company Halliburton, and subsidiary Kellogg Brown and Root, had received almost one-quarter billion dollars in payment for work done so far, with much more to follow. The total contract value stood at $\$ 2.3$ billion. ${ }^{9}$ In less than a year, additional federal contracts brought their total to more than $\$ 11$ billion. Among other tasks, the companies were responsible for the rebuilding of Iraq's oil-producing infrastructure.

Halliburton (and subsidiary KBR), though by far the largest contractor in Iraq, was only one of many dozens of similar corporations contracted for billions in reconstruction projects. Bechtel Group, also a corporation with solid government connections, signed contracts with the government valued at $\$ 2.8$ billion. Washington Group International, another well-connected firm with an interesting history in the federal contracting business, which I will explore in some detail below, signed on for around \$500 million for Afghanistan and more than $\$ 3$ billion for work in Iraq. Blackwater USA contracted to provide an array of security services valued at $\$ 21$ million. DynCorp, the private corporation charged with creating and training an Iraqi police force, contracted for around $\$ 93$ million. Vinnell Corporation (Northrop Grumman), tasked with training the New Iraqi Army (NIA), signed on for $\$ 48$ 
million. Fluor Corporation, a construction giant with some 50,000 employees in 25 countries spread across 6 continents, contracted for projects totaling $\$ 3.7$ billion in logistics support. CH2M Hill, a Colorado-based firm handling construction and engineering tasks, signed on for more than $\$ 1.5$ billion; and American International Contractors, Inc., specializing in an array of construction services, signed contracts valued at $\$ 1.5$ billion. Still, these were just a few of the more than one hundred corporations contracted for work in Iraq and Afghanistan. ${ }^{10}$

By late summer, independent experts estimated that one-third of the $\$ 3.9$ billion cost of the ongoing conquest and occupation of Iraq was devoted to private contractors. The flood of money to postwar Iraq (and Afghanistan) continued to grow. In November 2003, the Bush administration pushed for and the Congress appropriated $\$ 18.7$ billion to cover the initial costs of reconstruction and logistics work for Iraq. The pace of the work surprised nearly everyone, including officials at the Pentagon, who quickly found themselves inundated with not only requests and bids, but also complaints and accusations of cronyism, fraud, and corruption. Officials quickly established a central office to oversee the letting of contracts, stating, "The work in Iraq is moving at such an incredible pace that we needed one office to oversee everything." ${ }^{11}$ At the same time, representatives from hundreds of companies flocked to a Pentagon conference for contractors held in Arlington, Virginia, to hawk their particular wares and solicit work from the federal government. One excited conference attendee and prospective bidder pointed out, "There is just so much money that we can tap into. It's just wonderful to have this opportunity." 12 Before the year was out, more than 150 US corporations had received contracts worth some $\$ 50$ billion for work in Afghanistan and Iraq. ${ }^{13}$

These companies (as well as numerous subcontractors) scrambled to build and rebuild the infrastructure destroyed over the past dozen years. They began work on a police network, a military force, a communications grid, a transportation system, an integrated media system, the oil production and transportation system, water and sewage treatment systems, and ports. The number of those working for the contractors immediately climbed to between fifty thousand and seventy-five thousand, making the numbers working for private contractors in Iraq alone greater, by more than 2 to 1 , than the military forces making up what the Bush administration called the "coalition of the willing." 14 The contractor employees seemed even more willing. ${ }^{15}$

Many of the activities and practices of these private and largely unaccountable corporations were the object of sharp criticism from the public, media outlets, and congressional watchdogs. ${ }^{16}$ The way in which the contracts were let, for example, led to accusations of favoritism, cronyism, and conflicts of 
interest among government officials with close ties to the military industry. Former secretary of defense and head of Halliburton (and then vice president of the United States) Dick Cheney was only the most well-known and visible of these. Contracts awarded to Halliburton, KBR, and Bechtel raised congressional eyebrows because the contracts were awarded on the basis of an existing and past relationship with the federal government and were not open to any outside bidding process. In some cases, corporate representatives sat in on meetings at which they discussed the terms of the contract the company was about to receive, thus obliterating the line between the federal government and private firms.

Additionally, the contracts through which these deals were codified were known as "cost-plus-award-fee." This kind of contract stipulates that the government will pay for all costs associated with the job as well as an additional award fee based on performance. Most of them were arranged through either the US Defense Department or the Agency for International Development, and investigating officials were then unable to gain access to them in order to better understand the process. Although made illegal amid the revelations of World War I profiteering, this particular contractual device was decades ago revived and now flourishes in Iraq and Afghanistan. The cost-plus-award-fee arrangement permits rising profits as costs rise; all a contractor has to do to increase the former is to increase the latter. Consequently, curbing the costs of the work or project becomes disadvantageous to a corporation that might otherwise be keen to reduce costs in the interest of greater profits. Through these contracts, private corporations realized windfall profits by taking advantage of the relative urgency, chaos, and uncertainty of war. Despite clear evidence of fraud, mismanagement, corruption, and kickbacks, the Bush administration steadfastly refused to make the system transparent, and congressional committees of jurisdiction have also repeatedly refused to launch serious and public investigations. ${ }^{17}$

Congressman Henry Waxman, by far the most visible figure investigating and calling for greater scrutiny of the whole process, wrote that the Bush administration intended to reward a few handpicked companies by awarding "individual contractors monopolies over different sectors of the Iraqi economy." ${ }^{18}$ By spring 2004, there were some twenty-three hundred reconstruction projects planned, and none of the contracts for them were subject to competitive bidding. ${ }^{19}$ Evidence of corruption, kickbacks, bribery, and waste was pervasive.

One journalist wrote that "June 2004 has emerged as a month when both money and accountability were thrown out the window." June 2004 was, not coincidentally, the month for the official transfer of authority from the United 
States to the Iraqis, the dissolution of the American-run Coalition Provisional Authority (CPA). Referring to the unregulated atmosphere then prevailing in Iraq as "something like a Barneys warehouse sale in the Wild West," the Los Angeles Times disclosed official documents exposing a frenzied effort to rush contracts and otherwise logjammed projects through the system hurriedly to beat the deadline for the transferal of power. On just one day in late May, officials pushed through more than $\$ 1.5$ billion in spending for projects. In excess of one thousand contracts were signed in the month of June alone, roughly double the usual monthly figure. Two-thirds of those were signed without following standard procedures. Investigators later found refurbished schools and hospitals in a state of disrepair. Many projects remained incomplete or were not begun. In some places, piles of materials awaited the start of projects, and in others, workers waited for materials. Relying on official statements, the Los Angeles Times reported that even the oil and power infrastructures "are in worse shape than during the regime of Saddam Hussein." ${ }^{20}$

American officials in Iraq during this period conceded that the frenetic atmosphere led to unimaginable waste and corruption. In more than one instance, occupation officials were given large amounts of cash, $\$ 6.75$ million in one case, and told simply to get rid of it by the end of the month. Iraq was awash in pallets of shrink-wrapped bricks of cash-American soldiers actually played football with them to fight boredom. ${ }^{21}$

Those who worked closely with the firm Custer Battles LLC came forward to report shocking levels of bribery and kickbacks totaling untold millions. Halliburton (and subsidiary KBR) accepted bribes for handing out subcontracts from their posh villa in Kuwait, digs they had staked out well before the invasion of Iraq even began. With the invasion quickly over and the long and costly occupation begun, KBR proceeded to vastly overcharge the US government to transport fuel into Iraq and to provide meals to soldiers. The profiteering in this case climbed to more than $\$ 150$ million. Vinnell Corporation did such an apparently poor job of training Iraqi forces that the entire first battalion walked off the job, and the US Army had to take over. Employees from the security firm CACI International were deeply entangled in the prisoner abuse scandal at the Abu Ghraib facility. These and other companies remained virtually unaccountable for a time. By late 2005, however, a US District Court handed out the first formal indictments for instances of money laundering, bribery, wire fraud, conspiracy, and interstate transportation of stolen property. American officials working for the Coalition Provisional Authority, investigators soon discovered, had accepted bribes of hundreds of thousands of dollars to steer government contracts worth more than $\$ 13$ million to particular companies. The conspirators kept this hidden by writing 
bids not exceeding $\$ 500,000$. Any contract beyond that amount would be reviewed by higher-level officials. ${ }^{22}$

Overall, the rebuilding or state building in Iraq moved sluggishly along. A disproportionate share of money committed to Iraq was in fact devoted to dealing with military and security needs and related construction and not to the building/rebuilding campaign. Large-scale military campaigns launched against Al Fallujah and An Najaf aimed at defeating an increasingly sophisticated insurgency garnered inordinate energies as well as media coverage. Relatively little reconstruction aid had actually been spent. Of $\$ 18.4$ billion in the 2004 supplement, only $\$ 3.6$ billion was committed to relief and reconstruction efforts (about 35 percent of the goal). Of this figure, only $\$ 2.1$ billion had been obligated. ${ }^{23} \mathrm{As}$ of late 2005, the Congress had approved $\$ 20.9$ billion for the reconstruction of Iraq. Of that figure, $\$ 12$ billion had been spent. Additionally, estimates of the costs of increased security ran from 22 to 36 percent of each rebuilding project. Violent attacks and broad-based resistance to the American presence had continued to grow since 2003. Military officials reported dozens of attacks daily on US forces and Iraqis who cooperated with them. From May to September 2005, insurgent attacks killed more than three thousand in Baghdad alone. ${ }^{24}$

Reflecting the increased violence throughout Iraq, in March 2005, the US Agency for International Development (USAID) canceled two power generator projects to move $\$ 15$ million to ramp up security. Other projects were cut for the greater emphasis on security issues. These mounting costs resulted in dozens of millions in reconstruction aid being shifted away from rebuilding projects. Relatively optimistic estimates found that 1,887 of 2,784 projects had been completed. These included power stations, water treatment facilities, and police stations. In many cases, however, completed projects remained unusable. Five of the newly constructed electrical substations, built at a cost of $\$ 28.8$ million, sat idle because no system to distribute the power had been built. Others were hastily built and then neglected for lack of trained personnel or equipment availability and quickly fell into disrepair. Inspectors also found that millions of dollars had been squandered and wasted or completely lost. ${ }^{25}$ Despite successful building projects here and there, auditors and inspectors generally reported on the failure to rebuild Iraq's physical infrastructure. Even though more than $\$ 5.5$ billion was committed to restoring electricity service, according to a July 2005 Government Accountability Office (GAO) report, "power generation was still at lower levels as of May than it had been before the U.S. invasion in 2003." 26

Even for those features of state building for which money had been spent and some work done, the results were mixed at best. An independent investigator who traveled to Iraq to see the progress found supposedly rebuilt schools 
with leaky roofs, no working sewage systems, flooded playgrounds, unreliable electricity, missing and broken equipment, and peeling paint. All across Iraq's cities, the electrical grid was notoriously unreliable, and due to a rise in the incidence of cholera, kidney stones, and diarrhea, people did not generally trust that the water was potable. With hospitals and clinics still lacking adequate medicines, equipment, funding, and staffing, the nation's public health infrastructure also remained critically fractured. ${ }^{27}$

The US occupation authorities had as their central task the reversal of years of downwardly spiraling public health trends. A young population (half are under eighteen years of age), Iraqis were also saddled with high infant and childhood mortality rates; high general, chronic, and acute malnutrition rates; and an elevated rate of infectious disease. ${ }^{28}$ These conditions hit the young particularly hard. Chronic illness, such as high blood pressure and cholesterol, was much more prevalent among women and the elderly. More than 220,000 Iraqis lived with chronic illnesses directly attributed to war. The 2003 war in Iraq exacerbated these trends. A 2005 study concluded, "The proportion of chronically disabled in population groups that are not normally soldiersnamely women, children below nine and elderly above 60-is larger in the ongoing war than in the first Gulf war, and was in turn larger in the first Gulf war than in the Iran-Iraq war." ${ }^{29}$ Despite the seeming omnipresence of private contractors, remarkably little had been done to rebuild the physical infrastructure of the ravaged nation and to reverse these ominous trends.

As the months turned into years and as chaos engulfed Iraq, concerned officials and experts sought examples or lessons from history that might help solve these complicated problems. In doing so, they often settled upon those examples they believed successful, and least likely to highlight the very kind of failures they were encountering. As such, administration officials and academic experts rarely, if ever, invoked the American war in Vietnam. Despite the omnipresence of that war's long shadow since the 1960s, or perhaps because of it, it remains the elephant in the room everyone carefully navigates around as though it does not exist. ${ }^{30}$ The great irony here is, of course, that the war in Vietnam is perhaps the best place to go searching for insight. That war stands out as an example of nation-building in an atmosphere of war and the reliance upon private corporations to hastily put in place all the infrastructure of a modern state.

\section{PRIVATE CONTRACTORS, WAR PROFITEERING, AND STATE-BUILDING IN VIETNAM}

The United States initially became directly involved in Vietnam in the mid1950 s in an intentionally limited nation-building campaign. One of those 
limitations was the 17 th parallel — the US intended to build a separate, modern, and independent state in the southern half of the recently independent nation of Vietnam. While recognizing at least some of the difficulties of building a new nation where before no such nation had existed, the architects of US Cold War containment doctrine were nothing if not confident. Keeping the military presence limited and never imagining war, the administration of Dwight Eisenhower began to rely upon dozens of private contractors to carry out the construction of the new nation. Within half a dozen years, Vietnamese nationalists had organized an effective resistance and begun to fight back. Nation-building prescriptions alone were not working, and the United States faced the possibility of failure unless it beat back local resistance by increasing its own involvement in and aid to its client regime in the capital city of Saigon. ${ }^{31}$

Because southern Vietnam in the 1950s-1960s lacked anything approaching a modern communication and transportation infrastructure, significantly escalating the American presence also required substantial physical development. Consequently, in 1965 the administration of Lyndon B. Johnson breathed new life into a several-year-old $\$ 15$ million construction contract awarded to a two-firm consortium made up of Raymond International and Morrison-Knudsen (RMK). In 1996, Morrison-Knudsen, a construction giant based in Boise, Idaho, became Washington Group International following a merger. The Vietnam consortium, of which it was the lead sponsor, had handled military construction needs since 1962. Reliance on private firms to carry out the construction for a wider American presence would prevent having to escalate with tens of thousands of troops months earlier than eventually happened. ${ }^{32}$

By the spring of 1965 , construction allocations climbed to over $\$ 150$ million, and RMK could hardly keep pace. Construction projects quickly spread across much of southern Vietnam and involved bases, ports, ammunition dumps, airfields, radio installations, refugee camps, barracks, fuel depots, hospitals, and warehouses. By May the consortium had more than doubled its workforce from the 1964 level, hiring several hundred American construction workers and eleven thousand Vietnamese, largely as nonskilled laborers. Several months later, the orders still ran far ahead of the capacity of RMK alone. One exasperated MK official explained, "All we knew was that they wanted a lotta roads, a lotta airfields, a lotta bridges, and a lotta ports, and that they probably would want it all finished by yesterday." In early August, RMK brought on board two other large American construction firms, Brown and Root and J. A. Jones Construction, to form the RMK-BRJ. This consortium, frequently called the largest construction entity ever, became 
the sole contractor for the federal government for construction projects in Vietnam. The consortium, renaming itself the "Vietnam Builders" in 1966, played a key role in the American presence in Vietnam and ingratiated itself there just as much as the US military or the other exponents of the American mission. ${ }^{33}$

At its peak, the consortium's workforce numbered slightly more than 51,000, with around 47,000 Vietnamese, Koreans, Filipinos, and others, and 4,000 Americans overwhelmingly in supervisory and management roles. Within these numbers, however, this workforce changed a great deal. Over the life of the contract, the Builders employed between 180,000 and 200,000 Vietnamese. A high rate of turnover, the demands of the work, and the fluidity of a war environment in general gnawed away at cohesion and unity of purpose that the private contractors relied upon in their constant race to make deadlines and increase the pace of work on hundreds of simultaneous projects across southern Vietnam. ${ }^{34}$

That work environment was busier and the activity more frenetic than ever in 1966. The contractors expected to (and did) achieve $\$ 40$ million of work-in-place per month in the fall. Collectively, the various projects required close to $150,000,000$ board feet of lumber; 3,600 prefabricated buildings; $11,000,000$ pounds of nails; 750,000 sheets of plywood; and 98,000,000 pounds of asphalt, plus nearly 2,000 trucks and tractors, just to name a very few of the much-needed materials. Construction materials competed with an increasing flow of commodity aid, food aid, military aid, and all other imports for limited dock space, deep-draft berthing, and airfields. Once the needed materials did arrive, a reliable transportation system would have to then disperse the right supplies and equipment to the right job site out of the many hundreds then under way. The Builders also required the simultaneous construction of their own camps, demanding still more resources of labor, time, materials, and a system of efficient and rapid supply. ${ }^{35}$

During the life of the contract, the Vietnam Builders moved 91 million cubic yards of earth, used 48 million tons of rock product and nearly 11 million tons of asphalt, poured 3.7 million yards of concrete (enough to have built a wall 2 feet wide and 5 feet high completely around southern Vietnam), and moved an average of more than 500,000 tons of goods every month. Collectively and individually, they gobbled up hundreds of millions of dollars in profits for their efforts. In the process, Vietnam Builders employed 8,600 Americans and more than 51,000 Vietnamese. They built six ports with twenty-nine deep-draft berths, six naval bases, eight jet airstrips ten thousand feet in length, twelve airfields, just under twenty hospitals, fourteen million square feet of covered storage, and twenty base camps 
including housing for 450,000 servicemen and their families. In short, they put on the ground in southern Vietnam nearly $\$ 2$ billion (or $\$ 8.8$ billion adjusted) in construction of various kinds of facilities and infrastructure. Only when assessed in full measure does one begin to appreciate why those involved referred to their work as "the construction miracle of the decade." 36

The emphasis on preparation for war meant a diminution in emphasis on nation-building. While southern Vietnam's military-related infrastructure, roads and bridges, and ports and airfields became modernized, the war destroyed hamlets, villages, and farmland, turned peasants out as refugees, and generally disrupted the countryside in an overwhelmingly agrarian society. The resulting mass movement and forced urbanization exposed the absence of infrastructure in the urban environments as well. Access to decent housing, jobs and job training, health care and education, and measures to combat poverty and protect against vice and crime were notably absent. At the height of the war, the regime in Saigon spent less than 1 percent of its enormous US aid budget on public health. Incidences of cholera, dysentery, diarrhea, and malnutrition ballooned into a public health crisis. The number of orphans also shot up, reaching well over 10,000. The war also produced approximately 100,000 casualties each year, an estimated 30,000-50,000 amputees awaiting prosthetics they would likely never receive, and 4 million refugees out of a population of 14 million. $^{37}$

Tragically, the American aid program also contributed to the obstacles to state-building as it inundated southern Vietnam with an array of consumer goods, equipment, and people. The avalanche of goods and the resulting economic inflation, in fact, became one of the chief preoccupations of the American mission, officials back in Washington, and congressional investigators. In 1966, the United States sent to Vietnam $\$ 793$ million in economic aid and $\$ 686$ million in military aid. The level of aid dropped slightly in fiscal 1967 , but rose again to nearly $\$ 2$ billion for 1968 . Merchandise imports alone accounted for $\$ 650-\$ 750$ million of this aid package for each of those years. This influx of troops, equipment, money, and other goods in large quantities critically undermined the building of an indigenous economic base, even without the flood of people. At the same time, such infusions also created many opportunities for corruption, which became rife throughout the aid program. Congressional investigators found that an alarming quantity of aid goods never reached their intended targets but were diverted into the thriving black market that operated as a kind of shadow economy throughout much of the war. ${ }^{38}$ 
According to the USAID, "there was an inordinate amount of corruption-by any standard. The amount of corruption was far beyond that which could be tolerated under the grease-the-wheel theory." On the American side, too, corruption ran rampant in the black market, in currency manipulation scandals, theft, and more. Corruption ate into the program's effectiveness, its legitimacy, its members' morale, and its ability to carry out the ultimate aims of the United States. The USAID's final comprehensive report concluded, "There is little question that corruption ... was a critical factor in the deterioration of national morale which led ultimately to defeat." 39

There are many explanations for the pronounced level of corruption. Illinois representative Donald Rumsfeld, a member of the House investigative team, expressed his frustration over this problem:

I want this record and you gentlemen to know how disappointed I was at the discussions in Vietnam with AID personnel. Invariably the reason [our questions] could not be answered was because of the lack of records, the lack of audits, the lack of procedures whereby this information would be available.... I got the feeling ... that the information is not available. ... It is distressing for a . . member of a subcommittee to be attempting to come to grips with these problems, and to be repeatedly told that necessary and basic information is not available. ${ }^{40}$

The US aid economy was rife with corruption, graft, waste, and outright fraud. Rumsfeld also charged the administration with letting contracts that were "illegal by statute." He criticized in particular the infamous "Presidents Club," to which Brown and Root head George R. Brown, one of the principal Vietnam contractors, had given tens of thousands of dollars in campaign contributions. Rumsfeld pushed for full investigation into the whole affair, saying, "Under one contract, between the U.S. Government and this combine [RMK-BRJ], it is officially estimated that obligations will reach at least $\$ 900$ million by November $1967 .$. . Why this huge contract has not been and is not now being adequately audited is beyond me. The potential for waste and profiteering under such a contract is substantial." 41

As investigation uncovered waste and corruption in Vietnam, the war ground on, inexorably preventing ultimate success for the larger project of creating a new, modern, democratic nation below the 17 th parallel. For the United States, the war in Vietnam finally ended rather ingloriously in 1973, and the sovereign nation-state of "South Vietnam" still had never become a 
reality. Instead, much if not most of southern Vietnam lay in ruins, torn asunder by years of warfare extending back to the late 1940s.

\section{TOO BIG TO FAIL: MILITARY CONTRACTORS AND THE FUTURE OF US FOREIGN POLICY}

The once discernible line between the private sector and the public-military sector has continued to erode. In the case of Vietnam, the federal government relied upon a consortium of just four large firms for nearly all of its military construction needs. It selected those firms quite purposefully without any semblance of an open, competitive atmosphere. The firms were large and formed a collective reach and resource base unmatched by any competitors. In the case of Brown and Root, political connections also served them very well. Lyndon Johnson chose private contractors to somewhat quietly put in place an immense military infrastructure to allow for a greater American military role. Construction engineers and military planners quickly began to put in place an infrastructure complete with airfields; military bases; deep-draft ports; primary and secondary roadways; dredged canals; an electrical grid; water, fuel, and oil storage facilities; barracks; and hospitals. The project immediately consumed enormous sums of money and untold manpower, both American and Vietnamese. Indeed, this massive military construction project, aimed at greater security and making Vietnam defensible, siphoned critical resources away from state-building. This was a dilemma that President Johnson explicitly recognized. The private consortium allowed the president to escalate to a major war in Vietnam. It could accomplish a great many tasks quickly and efficiently. It could not, however, solve the greater crises of state-building. It could only temporarily mask those problems.

In Iraq, the level of corporate involvement, measured in either numeric terms or by a scale of the work responsibility, was at least as great as in Vietnam. Private firms carried out a range of tasks that, up until recently, the military did for itself. The line separating the military role from the private corporate role has become faint, to say the least. Corporations were charged with a vast rebuilding effort that was central to the larger aims of US policy in Iraq. In some cases, employees of private firms such as KBR who had no experience or training in combat found themselves in active combat zones at an operational level. In other cases, company employees were themselves exmilitary and used their specific training and skills in a combat setting for pay. More generally, the rise of what author P. W. Singer has termed the "Privatized Military Firm" ${ }^{42}$ also continues to erode the line between traditional military personnel, whose virtue has always been the public trust, and the privatized 
soldier for hire, whose interest is profit. Both cases seem to suffer a critical lack of coordination and oversight that weakens the pursuit of larger policy aims amid a diffusion of corruption and mismanagement.

At the same time, corporations such as Halliburton (KBR), LockheedMartin, Boeing, Bechtel, DynCorp, and Northrop-Grumman and hundreds of others have become relatively permanent fixtures in Pentagon circles. From logistics, supply, research and development, training, security, food preparation, and base-building, to maintenance and transportation, the American military relies heavily upon the private sector. The full effect of these relationships cannot at this point be fully known. There is little doubt that such a role for private contractors and the blurring of the line between them and the military no doubt impacts both the domestic and the foreign policy realm.

The private arm of US involvement in Afghanistan and Iraq is almost certainly a harbinger of things to come. It is also a manifestation of a powerful American militarism and an omnipresent military-industrial complex. That oft-used label once referred to the symbiotic relationship between the public military and the private arms makers. The concern, as President Dwight D. Eisenhower described it in his famous 1961 speech, was that the latter would come to have inordinate influence in the public realm. This depiction of that relationship seems almost quaint nowadays.

The Vietnam experience demonstrates the longevity of this trend. Corporations have long been deeply involved in the exercise of US foreign policy. Further, large, well-placed firms who regularly win government contracts have for decades assiduously cultivated their relationships with the government. Three of the four firms making up the Vietnam Builders ranked in the top ten of four hundred US construction and service companies who contracted with the federal government for 1966. All of them actually increased their rankings as a result of their work in Vietnam. Morrison-Knudsen moved from number 5 to 3; Brown and Root moved from number 7 to 2; J. A. Jones moved from number 25 to 17 . The final company of the consortium, Raymond International, ranked tenth among companies doing business outside the United States. ${ }^{43}$

Many of the corporations winning government contracts during the Vietnam War continue to win contracts for work in Afghanistan and Iraq. In 1966, the top four hundred firms winning contracts with the government included Bechtel Corp. (at number one), Brown and Root, Morrison-Knudsen (now Washington Group International), Ralph Parsons Company, and Fluor Corporation, all in the top ten. Other corporations contracted in Afghanistan and Iraq appearing on the list included the corporations of Foster Wheeler, Perini, and Vinnell. It should also be understood that government contracts 
for carrying out the war in Vietnam were not limited to just these few firms. Contracts were signed by 523 firms for various tasks and services related to the war. The top 62 held contracts worth more than $\$ 100$ million each. Familiar names such as American Machine and Foundry (AMF), Alcoa, Eastman Kodak, Bulova Watch Company, Magnavox, General Motors, McDonnell Douglas, Lockheed, DuPont, Boeing, and Honeywell all won contracts. It seems unnecessary to even point out that corporations came to see long-term, open-ended US foreign policy commitments such as Vietnam as business opportunities. As one General Motors executive told an interviewer in 1968, "We want to be known as a car and appliance manufacturer, not a merchant of war . . . but we also want to be ready to profit from the apparently endless series of brushfire wars in which the U.S. seems to involve itself." So great were the ties between the government's war in Vietnam and American corporations that a drawdown of forces in the early 1970s caused alarm for its potential harmful impact on the US arms/military industry and on the US economy generally. ${ }^{44}$

A significant corporate role in the execution of the government's foreign policy objectives, far from being a new phenomenon, is part of a very lengthy and complex tradition. The advocates of war in the private sector have long profited from its conduct. Do they now also influence the coming and process of war itself for that reason? For these mighty corporations to sustain themselves, ensure continued profits, stable share prices, and maintain their competitive advantage, they push for greater military spending, an increased role in the world in support of the military and preparations for war. Moreover, the relationship between corporate, government, and military officials and the revolving door of employment opportunities between them deepens and perpetuates these connections. Seen this way, US foreign policy interventions such as invasions, peacekeeping, sanctions enforcement, and state-building and -rebuilding all become job security. This institutionalization of war profiteering alters its historic meaning. Corporations once had to rely on the existence of the specific conditions of warfare for contracts and an opportunity for profits. The Cold War re-created these war conditions, albeit in the absence of outright warfare between the rival states. And although the post-Cold War period yielded a less-than-favorable environment, and forced a restructuring of the private arms and military support industry, the role played by privatized military corporations has continued to grow and even flourish. What has lagged behind these developments is any real and meaningful transparency, accountability, and working out of the relationship between the goals of US foreign policy and the ambitions of private firms. 


\section{NOTES}

Chapter title: "The lessons of the last war are clear," from General Dwight D. Eisenhower, "Scientific and Technological Resources as Military Assets," Memorandum, April 27, 1946. In Seymour Melman, Pentagon Capitalism: The Political Economy of War (New York: McGraw-Hill, 1970), appendix A. In this obscure memo, Eisenhower recommended the establishing of essentially a militaryindustrial complex, something he warned against in his more famous Farewell Address in 1961.

1. Andrew J. Bacevich, The New American Militarism: How Americans Are Seduced by War (New York: Oxford University Press, 2005).

2. See Norman R. Augustine, "The Last Supper, Revisited," DefenseNews, June 26, 2006.

3. The collusion here is thorough: both William Perry (undersecretary of Defense) and John Deutch (who went on to direct the CIA, 1995-1996) had been paid consultants for Augustine at Martin Marietta before joining the Clinton administration and thus had to obtain conflict-of-interest waivers from Les Aspin before putting this deal into place. See William D. Hartung, "Military-Industrial Complex Revisited: How Weapons Makers Are Shaping U.S. Foreign and Military Policies," in Global Focus: U.S. Foreign Policy at the Turn of the Millennium, ed. Martha Honey and Tom Barry (New York: St. Martin's Press, 2000), 21-43.

4. Joe Nocera, "From the Pentagon, a Buy Rating on Contractors," New York Times, February 12, 2011; Hartung, "Military-Industrial Complex Revisited." When Lockheed merged with Martin Marietta, Augustine netted \$8.2 million as a bonus.

5. James Dobbins et al., America's Role in Nation-Building: From Germany to Iraq (Santa Monica: Rand, 2003). Cheney quoted in Tom Ricks and Greg Schneider, "Cheney's Firm Profited from 'Overused' Army," Washington Post, September 9, 2000.

6. Peter W. Singer, "War, Profits, and the Vacuum of Law: Privatized Military Firms and International Law," Columbia Journal of Transnational Law 42, no. 2 (Spring 2004): 522. See also Singer, Corporate Warriors: The Rise of the Privatized Military Industry (Ithaca, NY: Cornell University Press, 2003). For a brief survey of the global activities of the Privatized Military Firms, see pp. 9-17.

7. Quoted in Office of the Special Inspector General for Iraq Reconstruction, Hard Lessons: The Iraq Reconstruction Experience from the Special Inspector General, Iraq Reconstruction (U.S. Independent Agencies and Commissions, 2009), 12.

8. Ibid., 34.

9. Maud Beelman, "Winning Contractors: U.S. Contractors Reap the Windfalls of Post-War Reconstruction," Center for Public Integrity, October 30, 2003, accessed April 19, 2005, http://www.publicintegrity.org; Michael Dobbs, "Iraq: Halliburton Reaping Huge Profits: One in Three Military Dollars Spent Goes to Contractors," Washington Post, August 28, 2003; Elizabeth Becker, "Details 
Given on Contract Halliburton Was Awarded," New York Times, April 11, 2003; Stephen J. Glain and Robert Schlesinger, "Halliburton Unit Expands War-Repair Role," Boston Globe, July 10, 2003.

10. Karen DeYoung and Jackie Spinner, "Contract for Rebuilding of Iraq Awarded to Bechtel," Washington Post, April 18, 2003; Elizabeth Becker and Richard A. Oppel Jr., "U.S. Gives Bechtel a Major Contract in Rebuilding Iraq," New York Times, April 18, 2003; Richard A. Oppel Jr., "Bechtel, the U.S. and Iraq: An Old Link," New York Times, April 19, 2003.

11. Sue Pleming, "U.S. Plans 24 New Contracts for Iraq by February," Forbes. com, November 18, 2003.

12. Sue Pleming, "Heady Days for Contractors in Race for Iraq Deals," Forbes. com, November 20, 2003.

13. Daniel Politi, "Winning Contractors-An Update," Center for Public Integrity, July 7, 2004, last accessed January 9, 2013, http://www.publicintegrity .org/2004/07/07/5629/winning-contractors-update. See also CorpWatch, "Top Military Contractors," last accessed January 13, 2013, http://www.corpwatch .org/article.php?id=11257.

14. Max Boot, "Different Rules for Contractors Put Military at Disadvantage," Sun-Herald, April 5, 2005.

15. Contractors such as Kellogg Brown and Root offered substantially higher salaries that were tax-free to induce Americans to go and work amid the dangers in Iraq. See Michael Serazio, "Gambling on Iraq," Houston Press, December 2-8, 2004, pp. 21-28. By 2005, 412 contracted workers and other civilian workers had died in Iraq. Approximately 147 of them were Americans; James Glanz, "U.S. Inquiry Cites Missteps in Iraqi Reconstruction," New York Times, October 30, 2005. As expected in such a fluid environment, the estimates of injuries, deaths, and suicides vary from source to source. See also John Ward Anderson and Steve Fainaru, "U.S. Confirms Killing of Contractors in Iraq: Four Were Slain by Angry Mob Last Month," Washington Post, October 23, 2005; and Anderson and Fainaru, "Roadside Bomb Kills Four American Contractors in Basra," New York Times, September 7, 2005.

16. Andrea Buffa and Pratap Chatterjee, "Houston, We Still Have a Problem," Corpwatch, May 17, 2005, last accessed January 9, 2013, http://www.corpwatch. org/article.php?id=12259. A much more detailed examination of Halliburton can be found in Buffa and Chatterjee, "Houston, We Still Have a Problem: An Alternative Annual Report on Halliburton,” May 16, 2005.

17. Edward Epstein, "Congress Curious about Iraq Deals," San Francisco Chronicle, May 20, 2003; Erik Eckholm, “The Billions: Top Army Official Calls for a Halliburton Inquiry,” New York Times, October 25, 2004. On the illegality of the cost-plus-award-fee contract, see Richard F. Kaufman, The War Profiteers (New York: Bobbs-Merrill, 1970), 118-19. Letter to Lt. General Robert Flowers, US Army Corps of Engineers, from Rep. Henry Waxman, March 26, 2003. Letter to Rep. Henry Waxman from Robert Flowers, April 8, 2003. Letter to David M. 
Walker, Comptroller General of the United States, General Accounting Office, from Rep. Henry Waxman and Rep. John Dingell, April 8, 2003. Letters to Lt. Gen. Robert Flowers from Rep. Henry Waxman, April 10, 2003 and April 16, 2003. Letter to Les Brownlee, Acting Secretary of the Army, from Rep. Henry Waxman, May 29, 2003. Letter to Honorable Donald Rumsfeld from Rep. Henry Waxman, April 30, 2003. Letter to Rep. Henry Waxman from Gen. Robert Flowers, May 2, 2003. Letter to William H. Reed, Director, Defense Contract Audit Agency, from Rep. Henry Waxman, February 12, 2004. Letter to Honorable Joseph E. Schmitz, Inspector General, U.S. Department of Defense, from Rep. Henry Waxman, February 24, 2004. Letter to David J. Lesar, President, Chairman, and CEO, Halliburton, from Rep. Henry Waxman, February 27, 2004. For specific details on Halliburton's contract abuses of the public trust, see Letter to Democratic Members of the House Government Reform Committee from Rep. Henry Waxman, March 10, 2004. All letters/correspondence available in PDF format at: http://www.house.gov/waxman/news_letters.htm (last accessed May 13, 2005). See also my editorial "Is Congress AWOL on Iraq?" History News Network, March 7, 2005.

18. Letter to Rear Admiral (ret.) David J. Nash, Director, Iraq Program Management Office, from Rep. Henry Waxman, December 18, 2003.

19. Statement of Rep. Henry A. Waxman, Ranking Minority Member, Committee on Government Reform. Hearing, Unprecedented Challenges: The Complex Task of Coordinating Contracts Amid the Chaos and the Rebuilding of Iraq, March 11, 2004.

20. T. Christian Miller, "Rules and Cash Flew Out the Window," Los Angeles Times, May 20, 2005. See also Craig S. Smith, "Poor Planning and Corruption Hobble Reconstruction of Iraq," New York Times, September 18, 2005.

21. Miller, "Rules and Cash"; and Ed Harriman, "Where Has all the Money Gone?" London Review of Books 27, no. 13 (July 7, 2005): 3-7; Callum Macrae and Ali Fadhil, "'Iraq Was Awash in Cash. We Played Football with Bricks of \$100 Bills," Guardian (London), March 20, 2006.

22. Letter to Hon. Joshua Bolten, Director, Office of Management and Budget, from Rep. Henry Waxman, September 30, 2003. Statement of Rep. Henry A. Waxman, Contracting Abuses in Iraq, October 15, 2003. Letter to Honorable Tom Davis, Chairman, Committee on Government Reform, from Rep. Henry Waxman, January 23, 2004. Letter to Hon. Joseph E. Schmitz, Inspector General, U.S. Department of Defense, from Rep. Henry Waxman, January 16, 2004. Memorandum for Corporate Administrative Contracting Officer, Defense Contract Management Agency San Antonio (DCMAW-GEHC), Defense Contract Audit Agency, January 13, 2004.

Neil King Jr., "Halliburton Tells Pentagon Workers Took Kickbacks to Award Projects in Iraq," Wall Street Journal, January 23, 2004; Boot, "Different Rules for Contractors"; Singer, "War, Profits, and the Vacuum of Law," 525; David Phinney, "Contract Quagmire in Iraq," Corpwatch, April 27, 2005; Phinney, "Halliburton 
Bribery Scandal Deepens," Corpwatch, March 29, 2005, last accessed January 9, 2013, http:/www.corpwatch.org/article.php?id=12011. Neela Banerjee, "2 in House Question Halliburton's Iraq Fuel Prices,” New York Times, October 16, 2003 ; Associated Press, "Army Eyes Halliburton Import Role in Iraq," November 5, 2003; Associated Press, "Audit: KBR Lost Track of Government Property in Iraq," November 26, 2004; James Glanz, "U.S. Should Repay Millions to Iraq, a U.N. Audit Finds," New York Times, November 5, 2005; Erik Eckholm, "Showcase: Rebuilding of Basra Progresses, but It's Harder Than Expected," New York Times, January 19, 2005; James Glanz, "American Faces Charge of Graft for Work Iraq," New York Times, November 17, 2005; Charles R. Babcock and Renae Merle, "U.S. Accuses Pair of Rigging Iraq Contracts," Washington Post, November 18, 2005.

23. As a 2004 study warns, however, "even 'obligated' does not mean that Iraqis are seeing any real progress in terms of actual project completions" (emphasis in original). See Anthony H. Cordesman, "Nation Building in Iraq: A Status Report" (Washington, DC: Center for Strategic and International Studies, 2004); and Michael R. Gordon, "Nation-Building in Iraq: Lessons from the Past," New York Times, November 21, 2003.

24. Peter Baker, "Bush Cites Setbacks in Rebuilding by the U.S.," Washington Post, December 8, 2005; Ellen Knickmeyer, "Baghdad Neighborhood's Hopes Dimmed by the Trials of War," Washington Post, September 27, 2005; Smith, "Poor Planning and Corruption."

25. Glanz, "U.S. Inquiry."

26. Renae Merle and Griff Witte, "Security Costs Slow Iraq Reconstruction, Contract Excesses Also Hamper Progress," Washington Post, July 29, 2005. An important indicator of rebuilding and a gauge of potential political trends is the fact that the average unemployment rate is 50-65 percent. See Robin Wright and Ellen Knickmeyer, "U.S. Lowers Sights on What Can Be Achieved in Iraq," Washington Post, August 14, 2005; and Spencer Ante, "A Hole in Bush's Iraq Exit Strategy," Business Week, April 19, 2005.

27. Pratap Chatterjee, Iraq, Inc.: A Profitable Occupation (New York: Seven Stories Press, 2004), 73-92. CorpWatch, "Investigation Reveals Reconstruction Racket in Iraq,” February 4, 2004, last accessed January 9, 2013, http://www .corpwatch.org/article.php?id=9849.

28. Central Organization for Statistics and Information Technology, Iraq Living Conditions Survey, vol. 2, Analytical Report (Baghdad: United Nations Ministry of Planning Development, 2005), see esp. chap. 3.

29. Ibid., 85 .

30. Robert MacMahon, "Contested Memory: The Vietnam War and American Society," Diplomatic History 26, no. 2 (Spring 2002): 159-84.

31. David L. Anderson, Trapped by Success: The Eisenhower Administration and Vietnam, 1953-1961 (New York: Columbia University Press, 1991).

32. A. H. Lahlum, Diary of a Contract (Saigon, July 1967), 22, RMK-BRJ Papers (all documents referred to as RMK-BRJ Papers were obtained from the 
companies involved and came in no discernible order or arrangement. They are all in the possession of the author [James M. Carter] ). Originally, the private consortium consisted of Raymond International and Morrison-Knudsen. In August 1965, Brown and Root and J. A. Jones Construction were both added in order to gain reach and access to greater resources commensurate with an expanded American military role and related construction needs in Vietnam.

33. "Military Construction in South Vietnam," Em-Kayan Magazine (November 1963): 8-9, RMK-BRJ Papers. Capt. Charles J. Merdinger, "Civil Engineers, Seabees, and Bases in Vietnam," U.S. Naval Institute Proceedings, no. 807 (May 1970): 261. The rate of work taking place was measured on a work-inplace (WIP) per-month basis. At the end of 1964, the WIP figure stood at $\$ 1.7$ million. By the next spring, it had leaped to more than $\$ 4$ million. As plans for expansion continued, the amount of work expanded, to an eventual peak of more than $\$ 65$ million WIP.

34. The Vietnamese workforce was increased from 4,900 to 11,000, a jump of nearly 125 percent. As of April 1965, according to Lahlum, Diary of a Contract, "every day some new and bigger phase of work was received and no diminishing of this trend was foreseen" (27-28); "Work Increases as Vietnam War Expands," Engineering News-Record 174, no. 19 (May 13, 1965): 25-28; "Construction Expands in South Viet Nam," Em-Kayan Magazine (June 1965): 7, RMK-BRJ Papers.

35. John Mecklin, "Building by the Billion in Vietnam," Fortune (September 1966): 114. Letter from MK to Raymond Intl., Brown and Root, and J. A. Jones, "Joint Venture Agreement," August 16, 1965; Letter from Lyman Wilbur (MorrisonKnudsen) to H. C. Boschen (Raymond International, Inc.), August 25, 1965, RMK-BRJ Papers. Carroll H. Dunn, Base Development in South Vietnam, 19651970 (Washington, DC: Department of the Army, 1972), 27. Lt. David L. Browne, "Dust and Mud and the Viet Cong," U.S. Naval Institute Proceedings, no. 811 (September 1970): 53-57. Cdr. W. D. Middleton, "Seabees in Vietnam," U.S. Naval Institute Proceedings, no. 774 (August 1967): 55-64, 60.

36. The contract extended to 1972, though the most intense period of construction was achieved during 1966-1968. Combined Completion Report, Basic Report, schedule 13, 1-3, RMK-BRJ Papers. "RMK-BRJ, The Vietnam Builders, 'The Construction Miracle of the Decade,"” RMK-BRJ Papers. Lahlum, Diary of a Contract. The combined result of these many projects made the defense of a piece of territory possible. Overall logistics capacity, from airfields to seaports, increased many times over during this brief period. The network of canals and rivers, and of roads, primary, secondary, and tertiary, also expanded many times over. This expanded capacity made possible the prosecution of a major war. By the middle of 1968, the United States had deployed more than 530,000 troops. The forces defending the Saigon regime, principally the ARVN, numbered 562,000 by the end of 1966. This force level, which needed also to be highly mobile and swift, required an immense and efficient logistics grid. 
37. Richard Eder, "U.S. Refugee Plan for Vietnam Set," New York Times, August 31, 1965. American officials even approached agencies of the United Nations for help with the crisis. See Richard Eder, "U.S. Seeking U.N. Aid for Vietnamese Refugees," New York Times, February 15, 1966.

38. Douglas C. Dacy, Foreign Aid, War, and Economic Development: South Vietnam, 1955-1975 (Cambridge: Cambridge University Press, 1986), 200; U.S. Agency for International Development (USAID), United States Economic Assistance to South Vietnam, 1945-1975, vol. 1 (Washington, DC: USAID, 1975), 8; (hereafter USEASV).

39. Ibid., 107.

40. An Investigation of the U.S. Economic and Military Assistance Programs in Vietnam, 42nd Report by the Committee on Government Operations, October 12, 1966 (Washington, DC: Committee on Government Operations, 1966), 16. Commodity Import Program for Vietnam (Follow-up Investigation) (Washington, DC: U.S. House of Representatives, Committee on Government Operations, 34th Report, October 1970), 9, 56, 62-63; USEASV, 224-26. For corruption within the US mission, see Fraud and Corruption in Management of Military Club Systems, Illegal Currency Manipulations Affecting South Vietnam (Hearings before the Permanent Subcommittee on Investigations of the Committee on Government Operations, United States Senate, 91st-92nd Congress, September 1969-March 1971), parts 1-8. William Allison, "War for Sale: The Black Market, Currency Manipulation and Corruption in the American War in Vietnam," War and Society 21, no. 2 (October 2003): 146.

41. Ibid.

42. Singer, "War, Profits, and the Vacuum of the Law."

43. "War Slows Equipment Deliveries," Engineering News-Record (February 17, 1966); "Leading Contractors Exploiting Industrial and Overseas Booms," Engineering News-Record (May 19, 1966).

44. Council on Economic Priorities, Economic Priorities Report (Washington, DC: Council on Economic Priorities, 1971). General Motors executive quote is from Sunday Times of London, April 21, 1968. See also Center for Strategic Studies, Economic Impact of the Vietnam War (Washington, DC: Georgetown University, 1967), esp. chap. 4; and Committee for Economic Development, The National Economy and the Vietnam War (New York: Research and Policy Committee of the Committee for Economic Development, 1968), 49-60.

\section{REFERENCES}

Allison, William. "War for Sale: The Black Market, Currency Manipulation and Corruption in the American War in Vietnam." War and Society 21, no. 2 (October 2003): 135-64.

Anderson, David L. Trapped by Success: The Eisenhower Administration and Vietnam, 1953-1961. New York: Columbia University Press, 1991. 
Anderson, John Ward, and Steve Fainaru. "U.S. Confirms Killing of Contractors in Iraq: Four Were Slain by Angry Mob Last Month.” Washington Post, October 23, 2005.

Ante, Spencer. "A Hole in Bush's Iraq Exit Strategy.” BusinessWeek, April 19, 2005.

Associated Press. "Army Eyes Halliburton Import Role in Iraq.” November 5, 2003.

- "Audit: KBR Lost Track of Government Property in Iraq." November 26, 2004.

Augustine, Norman R. "The Last Supper, Revisited.” DefenseNews, June 26, 2006.

Babcock, Charles R., and Renae Merle. "U.S. Accuses Pair of Rigging Iraq Contracts." Washington Post, November 18, 2005.

Bacevich, Andrew J. The New American Militarism: How Americans Are Seduced by War. New York: Oxford University Press, 2005.

Baker, Peter. "Bush Cites Setbacks in Rebuilding by the U.S." Washington Post, December 8, 2005.

Banerjee, Neela. "2 in House Question Halliburton's Iraq Fuel Prices.” New York Times, October 16, 2003.

Becker, Elizabeth. "Details Given on Contract Halliburton Was Awarded." New York Times, April 11, 2003.

Becker, Elizabeth, and Richard A. Oppel Jr. "U.S. Gives Bechtel a Major Contract in Rebuilding Iraq.” New York Times, April 18, 2003.

Beelman, Maud. "Winning Contractors: U.S. Contractors Reap the Windfalls of Post-War Reconstruction.” Center for Public Integrity, October 30, 2003. Accessed April 19, 2005. http://www.publicintegrity.org.

Boot, Max. "Different Rules for Contractors Put Military at Disadvantage." SunHerald, April 5, 2005.

Browne, David L. "Dust and Mud and the Viet Cong." U.S. Naval Institute Proceedings, no. 811 (September 1970): 53-57.

Buffa, Andrea, and Pratap Chatterjee. "Houston, We Still Have a Problem." Corpwatch, May 17, 2005. Last accessed January 9, 2013. http://www.corpwatch .org/article.php?id=12259.

—. "Houston, We Still Have a Problem: An Alternative Annual Report on Halliburton.” May 16, 2005.

Carter, James M. “Is Congress AWOL on Iraq?” History News Network, March 7, 2005.

Center for Strategic Studies. Economic Impact of the Vietnam War. Washington, DC: Georgetown University, 1967.

Central Organization for Statistics and Information Technology. Iraq Living Conditions Survey. Vol. 2, Analytical Report. Baghdad: United Nations Ministry of Planning Development, 2005.

Chatterjee, Pratap. Iraq, Inc.: A Profitable Occupation. New York: Seven Stories Press, 2004. 
Committee for Economic Development. The National Economy and the Vietnam War. New York: Research and Policy Committee of the Committee for Economic Development, 1968.

Cordesman, Anthony H. "Nation Building in Iraq: A Status Report." Washington, DC: Center for Strategic and International Studies, 2004.

CorpWatch. "Investigation Reveals Reconstruction Racket in Iraq," February 4, 2004. Last accessed January 9, 2013. http://www.corpwatch.org/article .php?id=9849.

—. “Top Military Contractors.” Last accessed January 13, 2013. http:// www.corpwatch.org/article.php?id=11257.

Council on Economic Priorities. Economic Priorities Report. Washington, DC: Council on Economic Priorities, 1971.

Dacy, Douglas C. Foreign Aid, War, and Economic Development: South Vietnam, 1955-1975. Cambridge: Cambridge University Press, 1986.

DeYoung, Karen, and Jackie Spinner. "Contract for Rebuilding of Iraq Awarded to Bechtel.” Washington Post, April 18, 2003.

Dobbins, James, John G. McGinn, Keith Crane, Seth G. Jones, Rollie Lal, Andrew Rathmell, Rachel Swanger, and Anga Timilsina. America's Role in NationBuilding: From Germany to Iraq. Santa Monica: Rand, 2003.

Dobbs, Michael. "Iraq: Halliburton Reaping Huge Profits: One in Three Military Dollars Spent Goes to Contractors." Washington Post, August 28, 2003.

Dunn, Carroll H. Base Development in South Vietnam, 1965-1970. Washington, DC: Department of the Army, 1972.

Eckholm, Erik. "The Billions: Top Army Official Calls for a Halliburton Inquiry." New York Times, October 25, 2004.

- "Showcase: Rebuilding of Basra Progresses, but It's Harder Than Expected.” New York Times, January 19, 2005.

Eder, Richard. "U.S. Refugee Plan for Vietnam Set." New York Times, August 31, 1965.

- "U.S. Seeking U.N. Aid for Vietnamese Refugees." New York Times, February 15, 1966.

Eisenhower, Dwight D. "Scientific and Technological Resources as Military Assets," Memorandum, April 27, 1946. In Seymour Melman, Pentagon Capitalism: The Political Economy of War, appendix A. New York: McGraw-Hill, 1970.

Epstein, Edward. "Congress Curious about Iraq Deals." San Francisco Chronicle, May 20, 2003.

Glain, Stephen J., and Robert Schlesinger. "Halliburton Unit Expands WarRepair Role.” Boston Globe, July 10, 2003.

Glanz, James. "American Faces Charge of Graft for Work Iraq." New York Times, November 17, 2005.

. "U.S. Inquiry Cites Missteps in Iraqi Reconstruction.” New York Times, October 30, 2005. 
"U.S. Should Repay Millions to Iraq, a U.N. Audit Finds." New York Times, November 5, 2005.

Gordon, Michael R. "Nation-Building in Iraq: Lessons from the Past." New York Times, November 21, 2003.

Harriman, Ed. "Where Has all the Money Gone?” London Review of Books 27, no. 13 (July 7, 2005): 3-7.

Hartung, William D. "Military-Industrial Complex Revisited: How Weapons Makers Are Shaping U.S. Foreign and Military Policies." In Global Focus: U.S. Foreign Policy at the Turn of the Millennium, edited by Martha Honey and Tom Barry, 21-43. New York: St. Martin's Press, 2000.

Kaufman, Richard F. The War Profiteers. New York: Bobbs-Merrill, 1970.

King, Neil, Jr. "Halliburton Tells Pentagon Workers Took Kickbacks to Award Projects in Iraq." Wall Street Journal, January 23, 2004.

Knickmeyer, Ellen. "Baghdad Neighborhood's Hopes Dimmed by the Trials of War." Washington Post, September 27, 2005.

"Leading Contractors Exploiting Industrial and Overseas Booms." Engineering News-Record (May 19, 1966).

MacMahon, Robert. "Contested Memory: The Vietnam War and American Society." Diplomatic History 26, no. 2 (Spring 2002): 159-84.

Macrae, Callum, and Ali Fadhil. "Iraq Was Awash in Cash. We Played Football with Bricks of \$100 Bills." Guardian (London), March 20, 2006.

Mecklin, John. "Building by the Billion in Vietnam." Fortune (September 1966).

Merdinger, Charles J. "Civil Engineers, Seabees, and Bases in Vietnam." U.S. Naval Institute Proceedings, no. 807 (May 1970): 261.

Merle, Renae, and Griff Witte. "Security Costs Slow Iraq Reconstruction, Contract Excesses Also Hamper Progress." Washington Post, July 29, 2005.

Middleton, W. D. "Seabees in Vietnam." U.S. Naval Institute Proceedings, no. 774 (August 1967).

Miller, T. Christian. "Rules and Cash Flew Out the Window." Los Angeles Times, May 20, 2005.

Nocera, Joe. "From the Pentagon, a Buy Rating on Contractors." New York Times, February 12, 2011.

Office of the Special Inspector General for Iraq Reconstruction. Hard Lessons: The Iraq Reconstruction Experience from the Special Inspector General, Iraq Reconstruction. U.S. Independent Agencies and Commissions, 2009.

Oppel, Richard A., Jr. "Bechtel, the U.S. and Iraq: An Old Link." New York Times, April 19, 2003.

Phinney, David. "Contract Quagmire in Iraq." Corpwatch, April 27, 2005.

—. "Halliburton Bribery Scandal Deepens." Corpwatch, March 29, 2005. Last accessed January 9, 2013. http://www.corpwatch.org/article.php?id=12011. Pleming, Sue. "Heady Days for Contractors in Race for Iraq Deals." Forbes.com, November 20, 2003. 
"U.S. Plans 24 New Contracts for Iraq by February." Forbes.com, November 18, 2003.

Politi, Daniel. "Winning Contractors-An Update." Center for Public Integrity. July 7, 2004. Last accessed January 9, 2013. http://www.publicintegrity. org/2004/07/07/5629/winning-contractors-update.

Ricks, Tom, and Greg Schneider. "Cheney’s Firm Profited from 'Overused' Army.” Washington Post, September 9, 2000.

Serazio, Michael. "Gambling on Iraq." Houston Press, December 2-8, 2004.

Singer, Peter W. Corporate Warriors: The Rise of the Privatized Military Industry. Ithaca, NY: Cornell University Press, 2003.

- "War, Profits, and the Vacuum of Law: Privatized Military Firms and International Law." Columbia Journal of Transnational Law 42, no. 2 (Spring 2004): 521-49.

Smith, Craig S. "Poor Planning and Corruption Hobble Reconstruction of Iraq." New York Times, September 18, 2005.

US Agency for International Development (USAID). United States Economic Assistance to South Vietnam, 1945-1975. Vol. 1. Washington, DC: USAID, 1975.

"War Slows Equipment Deliveries." Engineering News-Record (February 17, 1966).

"Work Increases as Vietnam War Expands." Engineering News-Record 174, no. 19 (May 13, 1965): 25-28.

Wright, Robin, and Ellen Knickmeyer. "U.S. Lowers Sights on What Can Be Achieved in Iraq." Washington Post, August 14, 2005. 


\title{
CHAPTER 5
}

\section{Crime, Low-Intensity Conflict, and the Future of War in the Twenty-First Century}

\author{
VANDA FELbab-Brown
}

Attempts to anticipate the future of war should be undertaken with great humility. Too often, analysts are too strongly influenced by immediate experiences; and determined not to repeat the mistakes of recent military endeavors, they are proven incorrect in their assumptions and planning for the future. After Vietnam, for example, the United States was determined not to get directly involved in another counterinsurgency campaign and structured its military doctrine around the use of overwhelming military power to be used only in cases of vital national interest. Yet, a few decades later, two of the largest US military interventions morphed into the costly, difficult, and longlasting counterinsurgency campaigns in Iraq and Afghanistan.

Similarly, the end of the Cold War led many analysts to conclude that large-scale interstate war was over. But is it? A US air attack on Iranian nuclear facilities could lead to Iran's firing surface-to-surface missiles at US ships, and subsequent US action to take out the missile batteries and disable Iran's nuclear facilities, leading potentially to major combat between US and Iranian ground troops. Although it may be true that given the preponderance of US military power, the United States will become involved in war against only enemies employing asymmetric capabilities and strategies, there can be great differences in asymmetric wars. During Israel's 2006 military foray into Lebanon to suppress Hezbollah, for example, Israel unexpectedly found itself facing a nonstate actor armed with capabilities typical of a state-air defenses, secure communications, and antitank and antiship weapons. While a future 
war with China-whether over Taiwan or to counter Chinese aggressive actions in the Asia-Pacific theater-would be extraordinarily costly and should be avoided, it is hardly inconceivable.

\section{THE COMPLEX SPECTRUM OF FUTURE WAR AND THE PERSISTENCE OF INTERSTATE WAR DESPITE ITS MANY ASYMMETRIES}

The end of the Cold War was accompanied by the widespread belief that the era of great-power wars was over. The Gulf War's Desert Storm campaign, at the cusp of the new era, was regarded by many analysts as probably the last major interstate military operation. The genocide in Rwanda, the rebellion in Chechnya, the interethnic violence in the former Yugoslavia, and the intensifying civil war in Colombia dominated the news. Scholars such as Mary Kaldor and Mark Duffield wrote of new wars-internal, disorganized, blurring the lines between civilians and combatants. ${ }^{1}$ Analysts focused on ethnic and religious wars, even raising the specter of a clash of civilizations. ${ }^{2}$ Partially in reaction to such arguments, scholars such as Paul Collier, Mats Berdal, David Keen, and others argued that increasingly wars were driven not by ideological ambitions or political grievances, but by economic profit motivations, and that wars created their own systems of economic rents, rather than representing a complete breakdown of order and economic structures. ${ }^{3}$ Even as states as governing entities with a monopoly on coercive power were seen to be failing in many regions, new structures and economic logics of internal conflict were seen to be arising.

Al-Qaeda's 9/11 attack against the United States propelled ideology—salafi jihadism, specifically—back into the focus of analysts, but nonstate actors and so-called ungoverned spaces where state presence was weak still dominated the content of military analysis. Counterinsurgency and civil war mitigation efforts became intertwined with counterterrorism. After all, a nonstate actor caused massive casualties inside the homeland of the greatest superpower. The United States was helping to fight terrorism and insurgency from the Philippines through Colombia, assisting in toppling the Islamic Courts Union, a group of Islamists that seized power in war-torn Somalia. Even the conventionally designed US Operation Iraqi Freedom, aimed at deposing the "rogue" regime of Saddam Hussein in Iraq and disabling its (nonexistent) weapons of mass destruction, quickly became embroiled in the intercommunal conflicts of the country and transformed into a full-blown counterinsurgency operation.

These various military efforts to alter the internal political arrangements in countries reasserted the influence of intelligence operatives - not in their 
Cold War cloak-and-fedora undercover incarnation, but instead in blurring the lines between them and special operations forces. Military actions abroad, such as in Pakistan where al-Qaeda and the Taliban found safe havens or in Somalia, featured high-tech robotics and unmanned vehicles often fed target information by ragtag warlords and proxies on horses. Such technologies have spread to nonstate actors, including criminal groups that already use cyber sabotage and who soon will have their own miniature drones. In the twentyfirst century, civilians are at risk not just from improvised explosive devices deployed by insurgents, but also potentially from cyber attacks on advanced societies, which could knock out electrical grids, cut off energy supplies to hospitals, paralyze trade and traffic, and sabotage secure facilities.

Especially after the protracted counterinsurgency wars in Iraq and Afghanistan, many NATO countries, including the United States, lost their taste for waging out-of-theater wars to alter internal conditions in other countries. Thus, offshore airstrikes and drone operations came to be embraced as a key tool of counterterrorism in the second decade of the twenty-first century instead of the boots on the ground that characterized the first decade. High-tech warfare with unmanned platforms controlled from remote command centers, combined with full-zone-of-conflict, real-time information, seems to promise that war can be neat, clean, and highly controllable even in remote places, the experience of Afghanistan and Iraq notwithstanding. ${ }^{4}$

These technologies have increased the sense not only that war can be controlled, discriminate, and sanitized, but also, by bringing to citizens in advanced societies real-time images of the suffering of distant poor oppressed peoples, that it can generate support for "responsibility-to-protect" (R2P) humanitarian military intervention. The brutality of the internal wars of the 1990s, during the era of great economic prosperity in North America and Western Europe, whetted the appetite and determination of Western governments to prevent any future genocidal wars and atrocities à la Rwanda. The notion that states can enjoy sovereignty from external intervention only as long as they protect their citizens from brutal human rights abuses was eventually codified in the Report of the International Commission on Intervention and State Sovereignty. ${ }^{5}$

But the protracted and painful wars in Iraq and Afghanistan and the economic difficulties that beset the United States and the European Union, the champions of the responsibility to protect doctrine, quickly soured their publics and leaders on interventions for reasons other than vital national security objectives. The deployment of local "peacekeeping" forces, such as those of the African Union, has been seen as an answer to the risks and costs of R2P interventions. Still, Western countries have not been able to resist the temptation 
to intervene at least from the air in the Libya conflict to depose Gadhafi, even if they were not willing to commit ground forces to prevent subsequent chaos, and to provide at least financial support to rebels and the Syrian population being slaughtered by the bloodthirsty Bashar al-Assad regime. But this great visibility, real-time communications, and information flows around the globe also mean that war messaging to domestic audiences is quickly transmitted to distant war theaters, often with undesirable foreign policy outcomes. Promises and mobilization of domestic audiences can no longer be confined to just them, but almost immediately also influences the resolve of faraway military opponents and attitudes of contested populations.

However, while the opening decade of the twenty-first century was seized with counterterrorism and regime change operations, interstate war was not fully absent in war planning. Nor will it likely be absent over the next several decades. Periodic military provocations by North Korea could have triggered a military confrontation with the South and drawn in the United States, and are hardly resolved in the second decade of the twenty-first century. Taiwanese independence ambitions flared up several times during the century's first decade; and both Chinese and US conventional, nuclear, and cyberwar forces are today being sized and designed for the possibility of someday having to fight one another in a cross-straits conflict. The increasingly passionate disputes over islands and underwater resources in the South China Sea could potentially trigger wars between China and Japan or China and the Philippines and even draw in the United States. In 1999, India and Pakistan fought their fourth war, and after the 2002 bombing of the Indian parliament by a Pakistani terrorist group, the two countries came perilously close to a fifth war, and continue to plan for that contingency.

Ominously, such confrontations on the Indian subcontinent have the potential to escalate into a nuclear exchange, given the precarious lines of control over the Pakistani nuclear arsenal and Pakistan's tendency to move nuclear-armed missiles during crises to avoid a disarming strike by India and a lack of crisis communications lines and early warning systems. Also, nuclear proliferation in the Middle East, triggered by Iran's determination to acquire nuclear weapons, could give rise to small and vulnerable nuclear arsenals in the Middle East that would put to the test concepts of mutual assured destruction and the existential deterrence capacity of nuclear weapons.

The very large spectrum of the shape of military conflict in the twenty-first century is underpinned by a structure of international relations characterized by great fluidity of alliances, unreliability of allies, and overall independence and nonalignment of major state actors as well as the presence of armed nonstate actors—what Seyom Brown calls "polyarchy." Supposed allies will find 
little motivation to join coalitions of the willing to counter faraway threats to the global order not just in direct military confrontations, but even in applying economic sanctions against rogue regimes (viz., the unwillingness of India, Brazil, and South Africa to join the sanctions regime against Iran, let alone the opposition of Russia and China). Local proxy forces feeding intelligence to drones will similarly find that their interests overlap only to a small extent with their distant patrons and will promote their often-problematic local agendas, many times double-crossing their external sponsors. Disharmony and lack of unity within the military coalitions will to a great extent characterize the spectrum of war in the twenty-first century.

\section{DOMESTIC CRIME AND ANTICRIME RESPONSES AS LOW-INTENSITY CONFLICT AND URBAN WARFARE}

An increasingly prominent kind of violence in large parts of the worldapproaching the intensity and shape of intrastate warfare-is the violence between criminal groups, but also the violence of states in their anticrime operations. Mexico today provides the most vivid, albeit extreme, example. Over the past several years, the country has suffered from drug-trade-related violence, extraordinarily intense and grisly even by criminal market standards. Mexico's drug war has claimed more than 51,000 lives since 2006, with over 16,000 just in 2011, and over 9,000 in 2012. ${ }^{7}$ Its drug trafficking organizations have been engaged in ever-spiraling turf wars over smuggling routes and corruption networks, turning the streets of some Mexican cities into macabre displays of gunfights and murders. The criminal groups have shown a determined willingness to fight Mexican law enforcement and security forces and an increasing ambition to control other illicit and informal economies in Mexico and to extort legal businesses. In parts of the country, criminal gangs dominate the lives of entire municipalities, and their reach extends to state governments. ${ }^{8}$ Controversially, some analysts have labeled the Mexico phenomenon and its spillovers into Central America as "criminal insurgency," a label that the government of Mexico has vociferously rejected."

Increasingly, not just remote rural peripheries but prominent urban areas will become the loci of potent crime. ${ }^{10}$ Karachi represents one such version of urban criminality and violence approaching low-intensity conflict and approximating a microcosm of a complex civil war, albeit with casualty levels only in the hundreds per year. The violence there is a witches' brew of terrorism, ethnic militancy and political mobilization, mafia fights, and landgrabbing. It is also deeply and intricately linked to major political actors in Pakistan, with both political parties and Pakistan's intelligence services, 
Inter-Services Intelligence (ISI), stirring ethnically based urban strife and manipulating criminal mafias to advance their political purposes. Political parties have taken advantage of the violence to demand monetary contributions and political votes from the population on the basis of ethnic divisions. The ISI has often used the strife in Karachi as a justification for its interventions in Pakistan's political system. ${ }^{11}$

Responses to urban crime also have increasingly come to approximate urban warfare. From Colombia’s Medellín to Jamaica's Kingston to Brazil's Rio de Janeiro to Mexico's Ciudad Juárez, governments have resorted to using heavily armed police or actual military forces to retake territories with urban slums with minimal state presence, essentially governed by criminal or insurgent groups. Brazil adopted such a heavy-force takeover policy toward its shantytowns in the 2000s, first in São Paulo and then in Rio de Janeiro. ${ }^{12}$ Rio's Pacification Policy (Unidade de Policía Pacíficadora [UPP]) toward the poor and crime-ridden favelas (slums) - home to 1.2 million of Rio's 6 million inhabitants-involving forcible takeovers and subsequent handovers to community police forces, has received widespread attention. ${ }^{13}$ As of November 2011, nineteen UPP outposts had been established in the favelas, mostly those close to the 2014 Soccer World Cup and the 2016 Rio Olympics venues and to major Rio arteries. Policies in both cities drew lessons from a similar pacification policy, Grupamento de Policiamento em Áreas Especiais (GPAE), implemented with varied and limited effectiveness in Rio de Janeiro's favelas in 2000. ${ }^{14}$ Both GPAE and UPP policies in Rio and its equivalent in São Paulo have sought to break with Brazil's historic pattern of deep social marginalization and isolation of the shantytowns by erecting physical walls around them, and resorting to highly repressive and violent, but only temporary, police excursions into the shantytowns controlled by criminal gangs.

In Mexico, President Felipe Calderón deployed the military into Mexico's streets to take over law enforcement functions in many of the country's cities, including Ciudad Juárez and Tijuana, which are troubled by intense violence generated by brazen and brutal drug trafficking organizations (DTOs). The strategy has been based on the premise that regular police forces in Mexico are so corrupt and hollowed out that they are unable to respond effectively to the violence and do not have the capacity to reduce the power of the DTOs. Once the military reduces the threat posed by the DTOs from a national security threat to a public safety problem and the police have been reformed, Calderón contended, the police would once again take over law enforcement functions. So far, Ciudad Juárez has seen the pullback of military forces and return of law enforcement to the police, even though extraordinarily high criminal violence in the city declined by only 24 percent from its peak levels, and the handover 
had as much to do with public dissatisfaction with military forces in the city as with their effectiveness in bringing down violence and criminality. ${ }^{15}$

In Colombia's Medellín, the counterinsurgency and anticrime policies in the 2000s also followed similar patterns. President Álvaro Uribe first sent the military to the city in 2002 to retake the poor comunas ruled by the leftist guerrilla group the Revolutionary Armed Forces of Colombia (the FARC). The success of this Operation Orion in defeating the FARC in Medellín allowed the crime-lord-cum-paramilitary-leader Don Berna to consolidate control over the criminal markets in the city. His firm control over the poor comunas and a panoply of criminal rackets in the city resulted in a significant drop in homicides throughout much of the first decade of the 2000s. Medellín mayors Sergio Fajardo and Alonso Salazar took advantage of greater security in the city and extended a host of development activities to the poor comunas, including infrastructure and public spaces such as libraries. In the latter part of the decade, Don Berna was imprisoned and extradited to the United States. His departure from the city gave rise to new violence in Medellín, as tens of criminal groups emerged and have fought over control of drug smuggling and distribution, prostitution, extortion, and gambling. ${ }^{16}$

Another example comes from Kingston, Jamaica, where for several decades the Tivoli Gardens neighborhood has been ruled by drug gangs linked to Jamaican political parties. Since the 1990s and until 2010, this garrison was ruled by the drug lord Christopher "Dudus" Coke. When then Jamaican prime minister Bruce Golding finally yielded to US pressure to arrest Coke and extradite him to the United States in 2010, Golding sent a heavy force to Tivoli Gardens in an operation that resembled urban warfare more than a standard police arrest. ${ }^{17}$ Coke ultimately surrendered to the United States, and Prime Minister Golding promised to adopt community policing and social development in Tivoli Gardens, though little has materialized so far.

In many of these countries, the state has been responding to violent challenges from "nongoverned spaces"- nongoverned only in the sense that they have not been governed by the states. The providers of governance there, brutal as it may be, have been violent nonstate actors such as gangs, criminal groups, and insurgents. ${ }^{18}$ The state there was not failing - in many of these rural peripheries and urban slums, it was never present and consolidated in the first place, and its governance has been mediated by and dependent upon arrangements with the ruling nonstate overlords.

Yet, more and more, these ignored marginalized areas and their troublesome actors have impinged upon life in the state-controlled spaces. Increasingly, perceptions of public safety and the state's effectiveness and accountability will be determined by how effectively the state devises responses to crime and 
insecurity in urban spaces. Yet in many of the world's major cities, law enforcement and social development have not caught up with the pace of urbanization, and there is a deep and growing bifurcation between developed and reasonably safe sectors of economic growth and social advancement and slums stuck in a trap of poverty, marginalization, and violence. Addressing the violence and lifting the slums from this trap will be among the major challenges for many governments.

\section{ANTICRIME POLICIES AS A COMPETITION IN STATE-MAKING}

An effective public safety and internal security response requires that responses to crime are conceptualized not as merely suppression of aberrant social behavior, but rather as a competition in state-making between the state and nonstate actors. Extensive criminality and illicit economies generate multiple threats to states and societies. They corrupt the political system by providing an avenue for criminal organizations to enter the political space, undermining democratic processes. Political entrepreneurs who enjoy the financial and political resources generated by their connections to illicit economies frequently experience great success in politics. They are able to secure official positions of power as well as wield influence from behind the scenes. The problem perpetuates itself as successful politicians bankrolled with illicit money make it more difficult for other actors to resist participating in the illicit economy, leading to endemic corruption at both the local and the national levels. Afghanistan, Guatemala, El Salvador, and Haiti are cases in point.

Large illicit economies dominated by powerful traffickers also have pernicious effects on a country's law enforcement and judicial systems. As the illicit economy grows, the investigative capacity of those systems diminishes. Impunity for criminal activity increases, undermining the credibility and deterrence effects of law enforcement, the judicial system, and the authority of the government. Powerful traffickers frequently turn to violent means to discourage prosecution, killing or bribing prosecutors, judges, and witnesses. Colombia in the late 1980s and Mexico today are powerful reminders of the corruption and paralysis of law enforcement as a result of extensive criminal networks and the devastating effects of high levels of violent criminality on the judicial system. The profound collapse and penetration by criminal entities of Guatemala's judicial system led the country to embrace a special UN body, the International Commission against Impunity in Guatemala (Comisión internacional 
contra la impunidad en Guatemala [CIGIG]), to help its judiciary combat organized crime and state corruption.

Illicit economies also have large and complex economic effects. Drug cultivation and processing, for example, generate employment for the poor rural populations and can even facilitate upward mobility. In Afghanistan, the drug economy amounts to 20 to 30 percent of Afghanistan's gross domestic product (GDP) and directly and indirectly employs about 20 percent of the population. ${ }^{19}$ Illicit economies can have powerful microeconomic spillover effects through boosting overall economic activity. Drug smuggling in the Mexican state of Sinaloa generates strong positive spillover effects for the overall economy in that locale by boosting demands for durables, nondurables, and services that would otherwise be absent. The drug trade there is estimated to account for 20 percent of Sinaloa's GDP, and for some of Mexico's southern states, the number might be higher. ${ }^{20}$ Indirectly, drug trafficking thus provides livelihoods to poor populations. Consequently, sponsorship of illicit economies is an important source of political capital for criminal organizations.

But a burgeoning drug economy also contributes to inflation and can hence harm legitimate, export-oriented, import-substituting industries as well as tourism. It encourages real-estate speculation, undermines currency stability, and also displaces legitimate production. Since the drug economy is more profitable than legal production, requires less security and infrastructure, and imposes smaller sunk and transaction costs, the local population is frequently uninterested in, or unable to participate in, other (legal) kinds of economic activity. The presence of a large-scale illicit economy can thus lead to a form of the so-called Dutch disease, where a boom in an isolated sector of the economy causes or is accompanied by stagnation in other core sectors since it gives rise to appreciation of land and labor costs. In Mexico, for example, the drug violence has not only undermined human security and public safety, but also decreased tourism in violence-affected areas, even as US firms continue to invest there. ${ }^{21}$

Most importantly, burgeoning and unconstrained drug production and other illicit economies and strong organized crime have profound negative consequences not only for local stability, security, and public safety, but, at times, also for national security.

\section{CRIME AND HUMAN SECURITY}

Although the threats that crime poses to the state may seem straightforward, the relationship between crime and society is often highly complex. For many 
people in areas of state weakness and multifaceted institutional deficiencies, participation in informal, if not outright illegal economies, such as the drug trade, is often the only way to satisfy their basic livelihood needs and obtain any chance of social advancement, even as they continue to exist in a trap of insecurity, criminality, and marginalization. The more the state is absent or deficient in the provision of public goods-starting with public safety and suppression of street crime and including the provision of dispute-resolution mechanisms and access to justice, enforcement of contracts, and the provision of socioeconomic public goods, such as infrastructure, access to health care, education, and legal employment-the more communities are susceptible to becoming dependent on and supporters of criminal entities and belligerent actors who sponsor the drug trade and other illegal economies.

By sponsoring illicit economies in areas of state weakness where legal economic opportunities and public goods are seriously lacking, both belligerent and criminal groups frequently enhance some elements of human security of those marginalized populations who depend on illicit economies for basic livelihoods, even while compromising other aspects of their human security and undermining national security. At the same time, simplistic law enforcement measures can and frequently do further degrade human security. These pernicious dynamics become especially severe in the context of violent conflict.

Belligerent groups thus obtain far more than simply increased physical resources from their participation in illicit economies. They also derive significant political capital—legitimacy with and support from local populations-from their sponsorship of the drug and other illicit economies, in addition to obtaining large financial profits. They do so by protecting the local population's reliable (and frequently sole source of) livelihood from the efforts of the government to repress the illicit economy. They also derive political capital by protecting the farmers (or in the case of other illicit commodities, the producers) from brutal and unreliable traffickers (bargaining with traffickers for better prices on behalf of the farmers); by mobilizing the revenues from the illicit economies to provide otherwise absent social services such as clinics and infrastructure, as well as other public goods; and by being able to claim nationalist credit if a foreign power threatens the local illicit economy.

Criminal groups also provide public goods and social services, suboptimal as they may be. ${ }^{22}$ In taking on such a role, Brazil's drug gangs, for example, have been able to dominate many of Brazil's poor urban areas, such as in Rio de Janeiro. Criminal groups and belligerents can even provide socioeconomic services, such as health clinics and trash disposal. 
Surprising as it may seem, since criminal groups are the source of insecurity in the first place, they often also regulate the level of violence on the street and establish order, suppressing particular manifestations of street crime, such as theft, robberies, and rapes. Organized-crime groups, such as the Primero comando da capital in São Paulo's shantytowns, also provide dispute resolution mechanisms and even set up unofficial courts and enforce contracts. ${ }^{23}$

Especially if nonstate actors sponsor labor-intensive illicit economies in the context of poverty, the absence of legal livelihoods, and state's efforts to suppress the illicit economy, their political capital can be large. ${ }^{24}$ Such political capital often motivates local populations to withhold intelligence on the belligerent group from the government if the government attempts to suppress the illicit economy. Accurate and actionable human intelligence is vital for success in counterterrorist and counterinsurgency efforts as well as law enforcement efforts against criminal groups.

From new warlords in Afghanistan to pirates in Puntland, such nonstate actors challenge not only the state by becoming alternative providers of public goods, but also traditional forms of governance and established tribal elites. By functioning as the distributors of socioeconomic goods and politicaleconomic regulators, they can transform themselves into protostates.

\section{A MULTIFACETED APPROACH TO COMBATING CRIME}

Precisely because nonstate actors, including criminal groups, can take on the trappings of the state's might and legitimacy, and in areas of their operations even surpass the state in both attributes, states need to define their response as a competition in state-making, rather than merely a suppression of aberrant social behavior. An effective anticrime response in such a context is a multifaceted state-building effort that seeks to strengthen the bonds between the state and marginalized communities dependent on or vulnerable to participation in the drug trade and other illicit economies for reasons of economic survival and physical insecurity. Such a multifaceted approach requires that the state address all the complex reasons why populations turn to illegality, including law enforcement deficiencies and physical insecurity, economic poverty, and social marginalization. Efforts need to focus on ensuring that individuals and communities will obey laws_-by increasing the likelihood that illegal behavior and corruption will be punished, but also by creating the social, economic, and political environment in which the laws are consistent with the needs of the people so that the laws can be seen as legitimate and hence be internalized. 
Although a law enforcement response to pervasive crime is rarely sufficient, it is always necessary. Without public safety and effective enforcement of rules and contracts, socioeconomic approaches to crime will struggle to take off, legal economies will be hampered, and high violence levels will deter investment from coming in and society from mobilizing. There are many elements to an effective law enforcement strategy-from establishing a permanent police presence and developing local police forces, to adopting approaches such as problem-oriented policing and community-based policing, and to determining whether to prioritize street crime or setting up specialized interdiction units, to undertaking a comprehensive police reform. A careful assessment of local conditions is required to determine which deficiencies need to be addressed in what sequence. ${ }^{25}$

But a state's effective response must also include well-designed socioeconomic policies to address some of the root causes of criminality and to strengthen the bonds between the population and the state. Generating legal livelihood alternatives to economically motivated participation in crime in turn requires that the economic development strategy addresses all the structural drivers of illegal economic production. Beyond providing for security and the rule of law, such a comprehensive approach requires that stable property rights be established, access to microcredit be developed, access to education and health care be expanded, and major infrastructure deficiencies be redressed. ${ }^{26}$

\section{INTERNATIONAL MILITARY FORCES AND THE NEXUS OF CRIME, TERRORISM, AND WAR}

Modern militaries have not been designed and trained to deal with illicit economies and organized crime. Nonetheless, since before World War II, major militaries have engaged with and sometimes taken on criminal actors. The Japanese occupation forces in Manchuria had to contend for control of Shanghai with the potent Green Gang, a criminal group led by Du Yuesheng. ${ }^{27}$ Relying on the mafia's assistance and intelligence provision was an integral part of the American campaign in Sicily during WWII. ${ }^{28}$ Many of the twentieth-century insurgencies, from Mao Tse-tung's Long March to the Shining Path in Peru, were deeply intermeshed with illicit economies, including the drug trade. ${ }^{29}$

The frequency and intensity of international military forces' interactions with the nexus of violent conflict and crime and with criminal actors have grown since the 1990s. International military forces have increasingly encountered illicit economies and criminal actors in undertaking humanitarian inter- 
ventions, such as in Somalia, and peacekeeping operations in civil wars, such as in Sierra Leone, and in dealing with terrorism and failed states. The Balkan wars and the international peacekeeping operations there were deeply overlaid with smuggling of various ilk and illicit economies often in reaction to, or spawned by, international sanctions and embargoes. ${ }^{30}$ Saddam Hussein's continuing frustration of international efforts to isolate his regime and bring it to heel came precisely from his ability to turn an international sanctions regime into a lucrative illicit economy. The counterterrorism, counterinsurgency, and state-building efforts in Afghanistan have been inextricably bound up with responding to Afghanistan's narcotics economy. In the first decade of the twenty-first century, the North Atlantic Treaty Organization (NATO), as well as individual countries ranging from the United States to Saudi Arabia to China, undertook a purely anticrime mission (i.e., the various antipiracy patrols off the coast of Somalia). How the revolutionary and social forces and postauthoritarian governments in Libya and Egypt manage to deal with the rise of organized and street crime and succeed in transforming enforcement from a tool of political oppression into an effective anticrime apparatus will to a large extent determine the fate of democracy and stability in the post-Arab Spring countries.

In encountering such illicit economies, international peacekeepers and outside intervention forces have had to grapple with difficult dilemmas: Criminal actors, including major warlords or key local political-military figures inside the official government of the country, can be potential spoilers in peace processes promoted by the international community. Consequently, for peace processes not to collapse, such actors often need to be brought into the new political arrangements; otherwise, the international forces need to bring resources to bear to neutralize such spoilers. The latter operations may require resources considerably in excess of what international forces are prepared to provide. The effort to neutralize such criminal actors is further complicated if they provide critical intelligence and other military assets. The United States, for example, relied on Afghan warlords, many of whom were or were to become major Afghan drug dealers, in its early operations in Afghanistan in 2001 and 2002 for intelligence and military operations. ${ }^{31}$

In other cases, political entrepreneurs with thick connections to the criminal world have systematically prolonged military conflicts to maintain access to high rents. Charles Taylor's machinations in Sierra Leone and Liberia to maintain access to the region's diamonds is probably the most notorious example. ${ }^{32}$ Moreover, the empowerment of such entrepreneurs through engagement with international forces or their admittance into the postintervention/ postconflict political system may bring about a form of governance 
that is extremely unpalatable not only to the international community sensitive to illegal economies such as the drug trade, but also to local populations subjected to the essentially discriminatory, predatory, and exclusionary mafia rule. Thus, the political system with deep linkages to criminal economies created in the wake of foreign intervention for the sake of stability may ultimately be highly unstable anyway. ${ }^{33}$ Yet, for reasons discussed above, efforts by the international community to destroy an illicit economy on which large segments of local population depend for basic livelihood may be equally detrimental to peace and stability and may in fact fuel conflict while alienating the population from the international forces.

\section{THE STATE AS MAFIA BAZAAR}

Nor is it correct to assume that crime and illicit economies in a postconflict country are always consequences of the conflict situation. The postconflict shape of crime, the power distribution in the criminal market and its reverberations in the political system, and the particular type of illicit economy into which crime evolves in the postconflict phase may be new. But often the postconflict criminal and political arrangements have roots in the preconflict patronage, corruption, and rent networks.

West Africa provides a good illustration. The level of drug trafficking there-especially cocaine from South America en route to Europe-has increased dramatically over the past decade. ${ }^{34}$ Driven by the newly intensified demand for cocaine in Western Europe, the shrinking of demand for cocaine in the United States, and the pressure on cocaine smuggling from interdiction operations in the Caribbean, the level of trafficking through West Africa has increased to a quarter of Europe's annual consumption. ${ }^{35}$ With some countries, such as Guinea-Bissau, appearing to be overrun by drugs and significant political instability, coups, and assassinations linked to organized crime and the drug trade in the country, analysts worry about the threat that the drug trade poses to the rule of law, political stability, and the quality of governance in the region.

However, many of these institutional conditions have existed for years in West Africa and predate the emergence of the current intense drug trafficking through the region. Neither illicit economies nor the drug trade are new to West Africa. Indeed, the region has been characterized by a variety of illicit economies and their deep integration into the political arrangements and frameworks of the countries in the region. Much of the political contestation in West Africa has focused on getting access to the state to control rents from various legal, semi-illegal, or outright illegal economies—such as diamonds 
(Sierra Leone and Liberia); gold and other precious metals, stones, and timber (Sierra Leone and Liberia); the extraction, monopolization, and smuggling of agricultural goods, such as cocoa (Côte d'Ivoire); trafficking in humans for sexual exploitation and domestic slavery (Mali, Togo, Ghana); oil (Nigeria); and fishing (often conducted illegally and destructively by international fleets from outside West Africa). Political contestation in these countries has often centered on taking over the state in order to control the main sources of revenue. In essence, the government has been seen as a means to personal wealth, not service to the people. ${ }^{36}$

Yet it would be a significant and often inappropriate leap of analysis to assume that "the drug trade epidemic" in West Africa will necessarily challenge political stability and threaten the existing governments and power of ruling elites. To the extent that external drug traffickers make alliances with the local nonelites-former or existing rebels not linked to the official system or young challengers who seek social mobility in an exclusive system-the traffickers will develop a conflictual relationship with the state, and political instability may well follow. To the extent that the governing elite captures the new rents, a symbiosis between external (and internal) drug traffickers and the ruling elites may develop. Drug traffickers will enjoy a sponsored safe haven; and while democratic processes and institutional development of the country will be threatened, political stability and the existing political dispensation may well be strengthened. ${ }^{37}$ In many parts of the world where international peacekeeping or foreign forces intervene for counterterrorism, humanitarian, or conflict-control objectives, they may well find a governance system built around criminal enterprises where the dispensation of exceptions from law enforcement by the country's elites to their clients and patronage networks is an organic form of governance.

\section{A CRIME-TERROR NEXUS?}

Similarly, whether the intensification of the drug trade in West Africa results in the emergence of a nexus with international terrorism is highly contingent on local conditions and the terrorist group's skills. The level and shape of law enforcement against illegal economies in West Africa will critically influence the tightness of the crime-terror nexus. It is critical to avoid inadvertently driving the two actors together.

Criminal and terrorist groups may share overlapping networks, tactics, and intelligence. They may even work through the same logistical operators. ${ }^{38}$ But although criminal groups and belligerent groups often interact with illicit economies in the same way, they have not morphed into a homogeneous 
monolithic entity. Rather, a crime-terror nexus is far from stable or necessarily inevitable. Indeed, such relations are often characterized as much by violent conflict between the criminal organizations and the terrorist groups as by cooperation. ${ }^{39}$ At most, such relationships are tactical alliances of mutual convenience.

Moreover, how successfully outside terrorist groups navigate new territories to which they may be drawn because of the presence of illicit economies depends on their intelligence capacity, their cultural and human terrain awareness, and their understanding of the complex relationship between official politicians, governing elites, and illegal economic networks.

\section{POLICY RESPONSES FOR DEALING WITH CRIME IN THE CONTEXT OF VIOLENT CONFLICT}

Devising policy for international counteraction to local illegal economies interlinked with belligerency is difficult in the abstract. Nonetheless, some important guidelines and considerations can be drawn from even this general description of the crime-conflict nexus.

The mandates for international peacekeeping forces need to be based on awareness that the more destroyed the legal economy is in the theater of intervention, the more robust and deeply ensconced the illicit economy will be. Prominent military and political actors in the region-possible allies or proxies of the intervention forces-will also very likely be deeply involved in the illicit economy, and their power inextricably linked to their ability to use the illicit economy to provide for the population's elemental needs. Conversely, however, the engagement of intervention forces with such actors will have profound effects on the shape of and the power distribution within the illicit economy, and thus within the country itself. Through their actions and engagement with local power brokers, international military forces will thus codify or alter the balance of power in the criminal market and hence in the political landscape.

Rushing to destroy an illicit economy, such as illicit crop cultivation, in the absence of readily available legal livelihoods will hamper the internationals' peacekeeping and counterinsurgency efforts. Moreover, in the absence of security and a strong on-the-ground presence, the effectiveness of any illiciteconomy suppression efforts will be highly limited as well. No matter what anticrime/counternarcotics efforts are ultimately undertaken—be it ironfisted suppression of the illicit economy or a prior fostering of legal alternative livelihoods - they will not be effective in reducing the illicit economy unless firm security throughout the entire territory has first been established. The 
state needs to be strengthened and conflict ended before efforts against illicit economies can be effective.

The more limited the scope of the outside intervention, the more limited will be the ability of the international forces to suppress or shape the crime-conflict nexus and illicit economies in the intervention area. Offshore, from-air interventions, as in the NATO operation against Gadhafi, give international actors a highly circumscribed ability to tackle local illicit economies. The more the intervention relies on local proxies, the higher the chance that they will capture not only political power in the postintervention phase but also the country's criminal markets. A criminal peace or peaceful criminal market run by the proxies may be the best the international community can hope for in such circumstances.

Expansion of the mission of international peacekeeping forces beyond the provision of security to direct efforts to reduce illicit economies and corruption requires that the international peacekeeping forces have a very detailed understanding of the intricacies of the local illicit economy and its nexus to violent conflict and the political and socioeconomic structures in the country. Such an enlargement of the traditional limited role of peacekeeping forces thus requires that the mission have a continual and robust information-gathering component that constantly monitors the effects the policies against illicit economies are having on the political and economic distribution of power in the area and on stability and development. Peacekeeping operations of this sort therefore must also have a robust analytical support component that includes political, economic, agricultural, anthropology, and criminology experts.

But, typically, outside intervention forces often not only have a poor capacity to understand local illicit economies and patronage networks of crime and politics, they often also lack the capacities to respond to crime. The absence of such capacities applies not only to organized crime but also to street crime. The rise in street crime is often the first and most direct way that local populations experience postintervention insecurity. Such an increase in street crime can again alienate the population from the state and the intervention force, stimulate a hankering for the regime ancien, empower extralegal power brokers, and even erect a criminal order. Yet both the outside intervention forces overall and their military police components are often ill-prepared to respond to street crime as well as to organized crime, nor can they effectively train local police forces. Neither military policing nor counterinsurgency-light approaches are adequate substitutes for traditional community-oriented policing skills. Thus, making a determined and systematic effort to develop police forces capable of tackling street crime and having training capacity geared 
toward the suppression of crime would greatly enhance the effectiveness of international interventions.

If outside military forces and their civilian counterparts decide to promote "good" governance and undo existing criminal enterprises and illicit economies and prevent the emergence of new ones, they need to plan for and take on this effort early in the mission. The immediate and early postintervention, post-military-operations period is the critical and optimal time to shape the political and criminal environment in the country. At that time, local power brokers have the most uncertainty about the future and show the greatest restraint in directly or covertly challenging the intervenor. Their networks of power have often been weakened by the collapse of the previous order and they have not had time to reconsolidate and reconstitute their new power networks.

In the early postintervention period, the local population is also most willing to work with the intervenor in setting up the new order. Under the best of circumstances, the people have disliked the previous political regime and are now hopeful about the future. At minimum, the locals will be uncertain about the power and capabilities of the intervenor and fearful of actively resisting it. Any institutions and political arrangements that survived the war may be at their most pliable - most susceptible to being molded by the outside intervenor. The longer the intervention forces wait to set up capable state structures, the harder the state-building effort becomes. Military opposition emerges. Local power brokers' criminal and political networks are established or reestablished, and the population loses faith in the future. Undoing such negative trends becomes harder and harder as more time elapses. Remobilizing the support of the population becomes especially difficult. The window of opportunity closes rapidly, and at some point reversing the bad trends may become impossible.

Afghanistan in the post-2001 years provides an apt example. In 2002 and 2003, the Taliban were scattered. The local population welcomed being liberated from the Taliban and welcomed the United States. Political elites, including the country's warlords empowered by the design of the US minimalist intervention that relied on them for crucial intelligence and military services, were often dependent on the United States for anchoring their power. They were also careful of not jeopardizing their relationship with the United States - even as Washington and the US military forces in Afghanistan failed to assert their leverage. President Hamid Karzai was actively asking the United States to rein in and disempower the warlords. But the longer the United States dithered and continued defining the mission in Afghanistan in minimalist terms of destroying the Taliban regime only as opposed to helping build a new 
state in Afghanistan, the more pernicious dynamics intensified. The Taliban insurgency erupted and grew in strength. The warlords became entrenched in the political system, and corruption, abuse, and nepotism intensified. President Karzai lost his wherewithal to challenge the warlords and instead bought them with state assets and foreign aid and came to tolerate their usurpation of power and resources. A subsequently more intense counterinsurgency campaign generated more deaths among the Afghan population, but no prospect of defeating the Taliban. The locals soured on America, and America soured on the Afghanistan effort. ${ }^{40}$

But it is important to recognize that the staying power of the international peacekeeping forces will always be inherently limited and that efforts to suppress illicit economies will be sustainable only if the population in the country and its political representatives have the economic and political incentives to support such policies.

It is unrealistic to expect that outside policy interventions can eradicate all organized crime and illicit economies or for that matter all the drug trade in the area of intervention. The priority for the international community should be to focus on the most disruptive and dangerous networks: those with the greatest links or potential links to international terrorist groups with global reach, those that are most rapacious and detrimental to society and the development of an equitable state, and those that most concentrate distribution of rents from illicit economies to a narrow clique of people. These three criteria may occasionally be in conflict, and such conflicts will pose difficult policy dilemmas. In addition to considering the severity of the threat posed to the international community and to the host state and society by such drug-trafficking or organized-crime groups, the estimated effectiveness of any policy intervention needs to be factored into the cost-benefit analysis of policy choices.

It is important to realize that indiscriminate and uniform application of law enforcement can generate several undesirable outcomes that need to be guarded against: First, the weakest criminal groups can be eliminated through such an approach, but it can inadvertently increase the efficiency, lethality, and coercive and corrupting power of the remaining criminal groups operating in the region. Second, such an application of law enforcement without prioritization can push criminal groups into an alliance with terrorist groups- the opposite of what should be the purpose of law enforcement and especially outside policy intervention. Both outcomes have repeatedly emerged in various regions of the world as a result of opportunistic, nonstrategic drug interdiction and law enforcement policies.

Finally, in determining whether and how to engage in the suppression of local illicit economies and organized-crime enterprises, the involved inter- 
national agencies need to ask themselves some hard questions and consider second- and third-order effects of their policies. For example, is it better to have illegal poppy cultivation in Pakistan rather than Afghanistan and if so, should antipoppy policies in Afghanistan be maximized? Will antipiracy efforts off the coast of Somalia push piracy from the Gulf of Aden into the wider Indian Ocean and would that be a better outcome? If the international community imposes sanctions on a particular country, will that give rise to new highly profitable smuggling enterprises, and by whom will the profits be captured? Such questions do not have easy answers, and governments tend to be loath to contemplate them. But without anticipating such likely adaptations of criminal markets and enterprises to any such international interventions, and doing a careful cost-benefit analysis of various policy options, governments may only make the violent conflict of the twenty-first century more challenging for themselves.

\section{NOTES}

1. See, for example, Mary Kaldor, New and Old Wars: Organized Violence in a Global Era (Stanford, CA: Stanford University Press, 1999); and Mark Duffield, Global Governance and New Wars: The Merging of Development and Security (London: Zed Books, 2001).

2. Samuel P. Huntington, "The Clash of Civilizations?" Foreign Affairs 72, no. 3 (Summer 1993): 22-49.

3. See, for example, Paul Collier and Anke Hoeffler, "On Economic Causes of Civil War," Oxford Economic Papers 50, no. 4 (October 1998): 563-73; Mats Berdal and David Keen, "Violence and Economic Agendas in Civil Wars: Some Policy Implications," Millennium 26, no. 3 (1997): 795-818; and David Keen, The Economic Functions of Violence in Civil Wars, Adelphi Paper No. 320 (Oxford: IISS/Oxford University Press, 1998).

4. For the dangers of assuming controllability of war as a result of technological advances and setting low thresholds for crossing over into military action, see Seyom Brown, The Illusion of Control: Force and Foreign Policy in the Twenty-First Century (Washington, DC: Brookings, 2003).

5. International Commission on Intervention and State Sovereignty, Responsibility to Protect (Ottawa: International Development Research Centre, 2001), http://responsibilitytoprotect.org/ICISS\%20Report.pdf.

6. Ibid.

7. Alfredo Corchado, "Violence Levels off in Some Parts of Mexico, but Spreads to Others," Dallas Morning News, February 4, 2012. Mexico's newspaper La reforma, which until November 30, 2012, reported drug-related homicides on a weekly basis, puts the number through November 2012 at 47,253, while other 
sources, including the Mexican government, put the 2006-2012 death toll at more than 60,000 .

8. For details, see Vanda Felbab-Brown, Calderón's Caldron: Lessons from Mexico’s Battle against Organized Crime and Drug Trafficking in Tijuana, Ciudad Juárez, and Michoacán (Washington, DC: Brookings, September 2011), http://www .brookings.edu/ /media/Files/rc/papers/2011/09_calderon_felbab_brown/09_ calderon_felbab_brown.pdf.

9. For pioneering work on the concept of criminal insurgencies, see, for example, John P. Sullivan, "Future Conflict: Criminal Insurgencies, Gangs and Intelligence," Small Wars Journal, May 31, 2009, http://smallwarsjournal.com/blog/ journal/docs-temp/248-sullivan.pdf?q=mag/docs-temp/248-sullivan.pdf.

10. For seminal work on urban criminality and urban spaces out of the control of the state, see Richard J. Norton, "Feral Cities," Naval War College Review 56, no. 4 (Autumn 2003): 97-106.

11. For details on Karachi, see "Into the Abyss," Economist, August 27, 2011; and Steve Inskeep, Instant City: Life and Death in Karachi (London: Penguin, 2011).

12. For the evolution of the policing response in São Paulo, see Jennifer Peirce, "Divided Cities: Crime and Inequality in Urban Brazil," Paterson Review 9 (2008): 85-98, http://www.diplomatonline.com/pdf_files/npsia/2009/PDF\%20-\%20 Jen\%20Peirce\%20-\%20Crime\%20and\%20Inequality\%20in\%20Urban $\% 20$ Brazil.pdf; Ted Goertzel and Tulio Kahn, "The Great São Paulo Homicide Drop," Homicide Studies 13, no. 4 (November 2009): 398-410; and Teresa P. R. Caldeira, City of Walls: Crime, Segregation, and Citizenship in São Paulo (Berkeley: University of California Press, 2001).

13. For an overview of the pacification policy, see, for example, Benjamin Lessing, "Depois da queda do Alemão: O futuro da guerra do tráfico" [After the fall of Alemáo: The future of Rio's drug war], O Globo Online: Favela Livre, December 16, 2010; and André Gomes Alves, "Segurança pública e polícia pacificadora: A fruição do direito a segurança pública nas favelas de Rio de Janeiro" [Public safety and police pacification: The attainment of the right to public security in the favelas of Rio de Janeiro] (University of Brasilia, June 2011), http://bdm.bce.unb.br/ bitstream/10483/1966/1/2011_AndreGomesAlves.pdf. For background on life in the favelas prior to UPP and the evolution of government policy responses, see, for example, Maria Helena Moreira Alves and Philip Evanson, Living in the Crossfire: Favela Residents, Drug Dealers, and Police Violence in Rio de Janeiro (Philadelphia, PA: Temple University Press, 2011); and Ben Pengalese, "The Bastard Child of the Dictatorship: The Comando Vermelho and the Birth of 'Narco-Culture' in Rio de Janeiro," Luso-Brazilian Review 45, no. 1 (2008): 118-45.

14. See, for example, Clarissa Huguet and Ilona Szabó de Carvalho, "Violence in the Brazilian Favelas and the Role of the Police," New Directions for Youth Development 119 (Fall 2008): 93-109; and Paul Chevigny, Edge of the Knife: Police Violence in the Americas (New York: Norton, 1995). 
15. For details on the strategy, its effectiveness in particular Mexican cities, and its overall accomplishments and shortcomings, see Felbab-Brown, Calderón's Caldron. For the overall security policy in Mexico, including its police and judicial reforms, civil-military relations, anti-money-laundering and anti-gun-control measures, and the role of the United States, see Eric L. Olson, David A. Shirk, and Andrew Selee, eds., Shared Responsibility: U.S.-Mexico Policy Options for Confronting Organized Crime (Washington, DC: Woodrow Wilson International Center, 2010).

16. For details, see Adam Isacson, "Medellín: Two Steps Forward, One Step Back," in Tackling Urban Violence in Latin America: Reversing Exclusion through Smart Policing and Social Investment (Washington, DC: Washington Office on Latin America, June 2011), 6-9; and Vanda Felbab-Brown, "Reducing Urban Violence: Lessons from Medellín, Colombia” (Washington, DC: Brookings, February 14, 2011), http://www.brookings.edu/opinions/2011/0214_colombia_ crime_felbabbrown.aspx.

17. For details on Jamaica's drug gangs, their relationship to political parties, and the 2010 operation to arrest Coke, see Enrique Desmond Arias, "A Desk Study of Jamaica," in Getting Smart and Scaling Up: The Impact of Organized Crime on Governance in Developing Countries, ed. Camino Kavanagh (New York: Center on International Cooperation, New York University, June 2013); and Amanda Silvers, Elections, Violence and the Democratic Process in Jamaica (Kingston: Ian Randle, 2010).

18. Anne L. Clunan and Harold A. Trinkunas, eds., Ungoverned Spaces: Alternatives to State Authority in an Era of Softened Sovereignty (Stanford, CA: Stanford University Press, 2010).

19. Estimates of the size of the drug economy as a percentage of GDP and the number of people it employs vary a great deal. For smaller, more narrowly based estimates, see United Nations Office on Drugs and Crime (UNODC), Afghanistan Opium Survey 2011, http://www.unodc.org/documents/crop-monitoring/ Afghanistan/Executive_Summary_2011_web.pdf. For larger estimates, see Christopher Ward and William A. Byrd, Afghanistan's Opium Drug Economy (World Bank Report No. SASPR-5, December 2004).

20. Guillermo Ibarra in Manuel Roig-Franzia, "Mexico's Drug Cartels Take Barbarous Turn: Targeting Bystanders," Washington Post, July 30, 2008.

21. Randal C. Archibold, "Despite Violence, U.S. Firms Expand in Mexico," New York Times, July 10, 2011.

22. For details, see Vanda Felbab-Brown, "Human Security and Crime in Latin America: The Political Capital and Political Impact of Criminal Groups and Belligerents Involved in Illicit Economies," Florida International University, Western Hemisphere Security Analysis Center, September 2011.

23. See, for example, Enrique Desmond Arias and Corrine Davis Rodrigues, "The Myth of Personal Security: Criminal Gangs, Dispute Resolution, and Identity in Rio de Janeiro's Favelas," Latin American Politics and Society 48, no. 4 (2006): 53-81. 
24. For details on the factors that influence the size of the political capital nonstate actors derive from sponsoring illicit economies and the complex interactions such actors have with illicit economies, see Vanda Felbab-Brown, Shooting Up: Counterinsurgency and the War on Drugs (Washington, DC: Brookings, 2009).

25 . For details on such aspects of law enforcement strategies in areas previously controlled by organized-crime groups, see Vanda Felbab-Brown, "Law Enforcement Actions in Urban Spaces Governed by Violent Nonstate Entities: Lessons from Latin America," Florida International University, Western Hemisphere Security Analysis Center, September 2011.

26. For details on the design of such anticrime socioeconomic policies, see Vanda Felbab-Brown, Bringing the State to the Slum: Confronting Organized Crime and Urban Violence in Latin America (Washington, DC: Brookings, December 2011), http://www.brookings.edu/papers/2011/1205_latin_america_slums_felbab brown.aspx.

27. Brian G. Martin, The Shanghai Green Gang: Politics and Organized Crime, 1919-1937 (Berkeley: University of California Press, 1996).

28. See, for example, Joshua Hammer, "In Sicily, Defying the Mafia," Smithsonian, October 2010, http://www.smithsonianmag.com/people-places/In-SicilyDefying-the-Mafia.html; and Alfred W. McCoy, The Politics of Heroin in Southeast Asia (New York: Harper and Row, 1972).

29. For a comprehensive list of insurgent and terrorist groups linked to the drug trade, see, Felbab-Brown, Shooting $U p$, appendix A.

30. See, for example, Peter Andreas, Blue Helmets and Black Markets: The Business of Survival in the Siege of Sarajevo (Ithaca, NY: Cornell University Press, 2008).

31. See Felbab-Brown, Shooting Up, chap. 5.

32. See, for example, William Reno, Corruption and State Politics in Sierra Leone (Cambridge: Cambridge University Press, 2009); and Reno, Warlords Politics and African States (Boulder, CO: Lynne Rienner, 1999).

33. For a detailed exploration of the dilemmas that peacekeepers encounter when dealing with the nexus of conflict and illicit economies and organized crime, see James Cockayne, "State Fragility, Organized Crime and Peacekeeping: Towards a More Strategic Approach," Norwegian Peacebuilding Resource Centre NOREF Report, September 2011, http://www.globalct.org/wp-content/uploads/2012/07/A_More_ Strategic_Approach_to_OC.pdf; and James Cockayne and Adam Lupel, eds., Peace Operations and Organized Crime: Enemies or Allies? (New York: Routledge, 2011).

34. United Nations Office on Drugs and Crime (UNODC), Transnational Trafficking and the Rule of Law in West Africa: A Threat Assessment (Vienna: UNODC, July 2009).

35. See, for example, James Cockayne and Phil Williams, The Invisible Tide: Towards an International Strategy to Deal with Drug Trafficking through West Africa (New York: International Peace Institute, October 2009); and Joseph Kirschke, "The Coke Coast: Cocaine and Failed States in Africa," World Politics Review, September 9, 2008. 
36. See, for example, George B. N. Ayittey, Africa in Chaos (New York: St. Martin's, 1999); and Geoffrey Wood, "Business and Politics in a Criminal State: The Case of Equatorial Guinea," African Affairs 103, no. 413 (2004): 547-67.

37. Vanda Felbab-Brown and James J. F. Forest, "Political Violence and the Illicit Economies of West Africa," Terrorism and Political Violence 24, no. 5 (2012): 787-806.

38. Douglas Farah, "Narcoterrorism and the Long Reach of U.S. Law Enforcement," Testimony in the U.S. House of Representatives House Committee on Foreign Affairs, Subcommittee on Terrorism, Nonproliferation and Trade, October 12, 2011, http://foreignaffairs.house.gov/112/fara101211.pdf.

39. Vanda Felbab-Brown, "Narcoterrorism and the Long Reach of U.S. Law Enforcement," Testimony in the U.S. House of Representatives House Committee on Foreign Affairs, Subcommittee on Terrorism, Nonproliferation and Trade, October 12, 2011, http://www.brookings.edu/testimony/2011/1012_terrorism_ drugs_felbabbrown.aspx.

40. This passage is based on Vanda Felbab-Brown's Aspiration and Ambivalence: Strategies and Realities of Counterinsurgency and State Building in Afghanistan (Washington, DC: Brookings, 2013). See also Luke Mogelson, "Which Way Did the Taliban Go?” New York Times Magazine, January 17, 2013.

\section{REFERENCES}

Alves, André Gomes. "Segurança pública e polícia pacificadora: A fruição do direito a segurança pública nas favelas de Rio de Janeiro" [Public safety and police peacemaker: The attainment of right to public security in the favelas of Rio de Janeiro]. University of Brasilia, June 2011. http://bdm.bce.unb.br/ bitstream/10483/1966/1/2011_AndreGomesAlves.pdf.

Alves, Maria Helena, and Philip Evanson. Living in the Crossfire: Favela Residents, Drug Dealers, and Police Violence in Rio de Janeiro. Philadelphia, PA: Temple University Press, 2011.

Andreas, Peter. Blue Helmets and Black Markets: The Business of Survival in the Siege of Sarajevo. Ithaca, NY: Cornell University Press, 2008.

Archibold, Randal C. "Despite Violence, U.S. Firms Expand in Mexico.” New York Times, July 10, 2011.

Arias, Enrique Desmond. "A Desk Study of Jamaica." In Getting Smart and Scaling Up: The Impact of Organized Crime on Governance in Developing Countries, edited by Camino Kavanagh. New York: Center on International Cooperation, New York University, June 2013.

Arias, Enrique Desmond, and Corrine Davis Rodrigues. "The Myth of Personal Security: Criminal Gangs, Dispute Resolution, and Identity in Rio de Janeiro's Favelas." Latin American Politics and Society 48, no. 4 (2006): 53-81.

Ayittey, George B. N. Africa in Chaos. New York: St. Martin's, 1999. 
Berdal, Mats, and David Keen. "Violence and Economic Agendas in Civil Wars: Some Policy Implications.” Millennium 26, no. 3 (1997): 795-818.

Brown, Seyom. The Illusion of Control: Force and Foreign Policy in the Twenty-First Century. Washington, DC: Brookings, 2003.

Caldeira, Teresa P. R. City of Walls: Crime, Segregation, and Citizenship in São Paulo. Berkeley: University of California Press, 2001.

Chevigny, Paul. Edge of the Knife: Police Violence in the Americas. New York: Norton, 1995.

Clunan, Anne L., and Harold A. Trinkunas, eds. Ungoverned Spaces: Alternatives to State Authority in an Era of Softened Sovereignty. Stanford, CA: Stanford University Press, 2010.

Cockayne, James. "State Fragility, Organized Crime and Peacekeeping: Towards a More Strategic Approach.” Norwegian Peacebuilding Resource Centre NOREF Report, September 2011. http://www.globalct.org/wp-content/ uploads/2012/07/A_More_Strategic_Approach_to_OC.pdf.

Cockayne, James, and Adam Lupel, eds. Peace Operations and Organized Crime: Enemies or Allies? New York: Routledge, 2011.

Cockayne, James, and Phil Williams. The Invisible Tide: Towards an International Strategy to Deal with Drug Trafficking through West Africa. New York: International Peace Institute, October 2009.

Collier, Paul, and Anke Hoeffler. "On Economic Causes of Civil War." Oxford Economic Papers 50, no. 4 (October 1998): 563-73.

Corchado, Alfredo. "Violence Levels off in Some Parts of Mexico, but Spreads to Others." Dallas Morning News, February 4, 2012.

Duffield, Mark. Global Governance and New Wars: The Merging of Development and Security. London: Zed Books, 2001.

Farah, Douglas. "Narcoterrorism and the Long Reach of U.S. Law Enforcement." Testimony in the U.S. House of Representatives House Committee on Foreign Affairs, Subcommittee on Terrorism, Nonproliferation and Trade, October 12, 2011. http://foreignaffairs.house.gov/112/fara101211.pdf.

Felbab-Brown, Vanda. Aspiration and Ambivalence: Strategies and Realities of Counterinsurgency and State Building in Afghanistan. Washington, DC: Brookings, 2013.

- Bringing the State to the Slum: Confronting Organized Crime and Urban Violence in Latin America. Washington, DC: Brookings, December 2011. http://www.brookings.edu/papers/2011/1205_latin_america_slums_felbabbrown.aspx.

. Calderón's Caldron: Lessons from Mexico's Battle against Organized Crime and Drug Trafficking in Tijuana, Ciudad Juárez, and Michoacán. Washington, DC: Brookings, September 2011. http://www.brookings.edu/ /media/Files/ rc/papers/2011/09_calderon_felbab_brown/09_calderon_felbab_brown.pdf.

- "Human Security and Crime in Latin America: The Political Capital and Political Impact of Criminal Groups and Belligerents Involved in Illicit 
Economies." Florida International University, Western Hemisphere Security Analysis Center, September 2011.

. "Law Enforcement Actions in Urban Spaces Governed by Violent Nonstate Entities: Lessons from Latin America." Florida International University, Western Hemisphere Security Analysis Center, September 2011.

_. "Narcoterrorism and the Long Reach of U.S. Law Enforcement." Testimony in the U.S. House of Representatives House Committee on Foreign Affairs, Subcommittee on Terrorism, Nonproliferation and Trade, October 12, 2011. http://www.brookings.edu/testimony/2011/1012_terrorism_drugs_felbab brown.aspx.

. "Reducing Urban Violence: Lessons from Medellín, Colombia." Washington, DC: Brookings, February 14, 2011. http://www.brookings.edu/opinions /2011/0214_colombia_crime_felbabbrown.aspx.

- Shooting Up: Counterinsurgency and the War on Drugs. Washington, DC: Brookings, 2009.

Felbab-Brown, Vanda, and James J. F. Forest. "Political Violence and the Illicit Economies of West Africa." Terrorism and Political Violence 24, no. 5 (2012): 787-806.

Goertzel, Ted, and Tulio Kahn. "The Great São Paulo Homicide Drop." Homicide Studies 13, no. 4 (November 2009): 398-410.

Hammer, Joshua. "In Sicily, Defying the Mafia." Smithsonian, October 2010. http:// www.smithsonianmag.com/people-places/In-Sicily-Defying-the-Mafia.html.

Huguet, Clarissa, and Ilona Szabó de Carvalho. "Violence in the Brazilian Favelas and the Role of the Police." New Directions for Youth Development 119 (Fall 2008): 93-109.

Huntington, Samuel P. "The Clash of Civilizations?" Foreign Affairs 72, no. 3 (Summer 1993): 22-49.

Inskeep, Steve. Instant City: Life and Death in Karachi. London: Penguin, 2011.

International Commission on Intervention and State Sovereignty. Responsibility to Protect. Ottawa: International Development Research Centre, 2001. http:// responsibilitytoprotect.org/ICISS\%20Report.pdf.

Isacson, Adam. "Medellín: Two Steps Forward, One Step Back.” In Tackling Urban Violence in Latin America: Reversing Exclusion through Smart Policing and Social Investment. Washington, DC: Washington Office on Latin America, June 2011.

Kaldor, Mary. New and Old Wars: Organized Violence in a Global Era. Stanford, CA: Stanford University Press, 1999.

Keen, David. The Economic Functions of Violence in Civil Wars. Adelphi Paper No. 320. Oxford: IISS/Oxford University Press, 1998.

Kirschke, Joseph. "The Coke Coast: Cocaine and Failed States in Africa." World Politics Review, September 9, 2008.

Lessing, Benjamin. "Depois da queda do Alemão: O futuro da guerra do tráfico" [After the fall of Alemáo: The future of Rio's drug war]. O Globo Online: Favela Livre, December 16, 2010. 
Martin, Brian G. The Shanghai Green Gang: Politics and Organized Crime, 19191937. Berkeley: University of California Press, 1996.

McCoy, Alfred W. The Politics of Heroin in Southeast Asia. New York: Harper and Row, 1972.

Mogelson, Luke. "Which Way Did the Taliban Go?” New York Times Magazine, January 17, 2013.

Norton, Richard J. "Feral Cities." Naval War College Review 56, no. 4 (Autumn 2003): 97-106.

Olson, Eric L., David A. Shirk, and Andrew Selee, eds. Shared Responsibility: U.S.-Mexico Policy Options for Confronting Organized Crime. Washington, DC: Woodrow Wilson International Center, 2010.

Peirce, Jennifer. "Divided Cities: Crime and Inequality in Urban Brazil." Paterson Review 9 (2008): 85-98. http:/www.diplomatonline.com/pdf_files/ npsia/2009/PDF\%20-\%20Jen\%20Peirce\%20-\%20Crime\%20and\%20Inequality\%20in\%20Urban\%20Brazil.pdf.

Pengalese, Ben. "The Bastard Child of the Dictatorship: The Comando Vermelho and the Birth of 'Narco-Culture' in Rio de Janeiro." Luso-Brazilian Review 45, no. 1 (2008): 118-45.

Reno, William. Corruption and State Politics in Sierra Leone. Cambridge: Cambridge University Press, 2009.

- Warlords Politics and African States. Boulder, CO: Lynne Rienner, 1999.

Roig-Franzia, Manuel. "Mexico's Drug Cartels Take Barbarous Turn: Targeting Bystanders." Washington Post, July 30, 2008.

Silvers, Amanda. Elections, Violence and the Democratic Process in Jamaica. Kingston: Ian Randle, 2010.

Sullivan, John P. "Future Conflict: Criminal Insurgencies, Gangs and Intelligence.” Small Wars Journal, May 31, 2009. http://smallwarsjournal.com/blog/ journal/docs-temp/248-sullivan.pdf?q=mag/docs-temp/248-sullivan.pdf.

United Nations Office on Drugs and Crime (UNODC). Afghanistan Opium Survey 2011. http://www.unodc.org/documents/crop-monitoring/Afghanistan/ Executive_Summary_2011_web.pdf.

. Transnational Trafficking and the Rule of Law in West Africa: A Threat Assessment. Vienna: UNODC, July 2009.

Ward, Christopher, and William A. Byrd. Afghanistan's Opium Drug Economy. World Bank Report No. SASPR-5, December 2004.

Wood, Geoffrey. "Business and Politics in a Criminal State: The Case of Equatorial Guinea." African Affairs 103, no. 413 (2004): 547-67. 

Systematic Response 



\title{
CHAPTER 6
}

\section{Odious and Failed States, Humanitarian Responses}

\author{
Robert I. ROTBERG
}

Repressive, odious nation-states eventually implode. That is at least one of the significant messages of the Arab spring, summer, and autumn of 2011. But such states—the worst of the worst—never implode neatly, effortlessly, or, in the most difficult cases, without external assistance. How to calibrate that external assistance so that it can produce the greatest benefit for the greatest number of impacted and oppressed citizens is one important question. A second is the equally thorny question of how the world order might best respond to cries of oppression from within despotisms and tyrannies before internal implosions occur. Absent the rising up of civil forces in repressive nationstates, indeed, before there is any obvious tumult, what is the responsibility of the world order? Does the responsibility-to-protect (R2P) doctrine have any significant policy power going forward? Should the world order plan to build upon its successful employment during the interventions in Libya and Mali? If so, how?

\section{REPRESSIVE STATES}

There is a class of nation-state, possibly numbering a dozen at any one time, that so abuses its own people that it deserves to be classified as odious. Indeed, some of the greatest threats to global stability in this century come not from the hegemonic powers battling one another, but from smaller, much less intrinsically powerful entities refusing to follow the principles of civility that customarily guide, or are supposed to guide, world order. These outlaw nations, mostly near-failed, failed, or collapsed states, attack their own 
peoples, show little respect for the human rights of their subjects, deny civil liberties and essential freedoms, and at best pretend to be democratic. ${ }^{1}$ These heavy repressors breach official conventions and treaties such as the International Covenant on Economic, Social, and Cultural Rights and the International Covenant on Civil and Political Rights. Again and again they offend against global human rights norms. A handful of these internally demonic nation-states also behave provocatively in their regions by being nasty to their neighbors or by being serial offenders against international norms of proper behavior. But in the main these kinds of states imperil the peace of the world primarily by abusing their inhabitants so severely that instability and internal conflict are likely outcomes.

Those states that thus operate beyond the international normative pale are characterized by the withdrawal of fundamental human rights and civil liberties from their own peoples. They mock democracy. They employ the mailed fist to compel obedience and achieve compliance and conformity. They obliterate the rule of law, assassinating and imprisoning opponents. They take political prisoners, employ collective punishment of families or lineages, and apply rules and sanctions capriciously. They run command economies that restrict individual entrepreneurial initiative and opportunity to themselves and their clients and are wildly corrupt. Wealth sticks to their hands and the hands of their close associates, even if vast numbers of citizens go hungry or starve. In nearly all cases these regimes depend upon a leader's personality cult; ideologies are far less salient than mere obedience. Cultures of dependency and conformity result.

Terror inhabits most of these repressive nation-states. Their rulers are arbitrary and unpredictable, the better to intimidate their agents and their citizens. They often succeed in inculcating a widespread feeling of mental impotence and lethargy among their subjects. Heavy-handed presidents and prime ministers hence cow their citizens by a succession of quixotic, idiosyncratic, ruthless behaviors and by seductive exercises of co-optation-sometimes mixed with mindless brutalities. Malevolent rulers like those of Fidel Castro's Cuba, Saddam Hussein's Iraq, Ayatollah Khomeini's Iran, Pol Pot's Cambodia, Than Shwe's Burma, Kim Jong Il's North Korea, the Turkmenbashi's Turkistan, François (Papa Doc) Duvalier's Haiti, Idi Amin's Uganda, Jean-Bedel Bokassa’s Central African Empire, Teodoro Obiang Nguema Mbasogo's Equatorial Guinea, and Robert Mugabe's Zimbabwe manipulate and suppress their followers and their countries by spontaneous cruelties, thuggishly maintained obedience, harsh reprisals, deprivations (of food or freedoms), and mindnumbing speechifying. Subjects cannot easily escape, defect, or protest—until suddenly they do. 
Using these and similar indicators such as counting political prisoners or observing the rise in rates of infant mortality, it is possible to separate the most offensive nation-states - the worst of the worst-from those who are merely smaller-scale abusers. To do so, and in order to compare and contrast one oppressive despotism from another, we need to discover each regime's current numbers of political prisoners, house arrestees, secret incarcerations, murders or attempted murders of political opponents, unexplained disappearances, and instances of torture. We need further to document cases of collective punishment, impositions of conformity, and the duration of pretrial detention of political offenders. We want to know the extent of rape and other violence against women, the number of forced abortions, the prevalence of child labor, and the scale of trafficking of women, children, small arms, and narcotics. ${ }^{2}$

We can further assess a regime's repressiveness by counting its police per capita; the number of security forces per capita (North Korea's and Burma's are unusually high); the scope of interference with privacy; the imposition of restrictions to religious freedom; the use of travel bans (internal and external); curtailments of freedom of expression, speech, and the media; the absence of freedom of assembly and association (very common); abuses of the rule of law; the denial of judicial independence; the use of food and hunger as controlling instruments; externally estimated depths of corruption; the imposition of personality cults (as in the "Little Green Book"); harassment of Internet use; and discrimination against minorities.

When we use such screens to sort among the world's 194 or so recognized nation-states for gross repressiveness and mere high repressiveness, we rapidly develop a list of nation-states that are of extreme concern to world order because of the harmful manner in which they brutalize their own citizens. Admittedly, the screens depend on the kinds of data that are difficult to obtain; odious states are usually loath to provide statistics giving the number of political prisoners, assassinations, and torture victims. Nor do they willingly admit to the deployment of collective punishment or mass starvation as weapons of repression. Nevertheless, employing a myriad of estimates, proxy measures, and smuggled data, it is possible at any one point in time to focus on nation-states where populations are severely at risk. ${ }^{3}$ Reports filed by the likes of various United Nations rapporteurs; Human Rights Watch; Amnesty International; relief and development organizations such as Doctors without Borders, Mercy Corps, and Care International; internally and externally based journalists; and scholars inside and outside the relevant countries, all contribute significant observations capable of being aggregated and scrutinized. Not least, respected internationally compiled assessments such as Transparency International's corruption perceptions index, the UN Development Program's 
human development index (HDI), and various estimates of maternal mortality and life expectancy prepared by the World Health Organization offer comparative insights into a nation-state's weaknesses and strengths. If GDPs per capita are stagnant or falling, if life expectancy is sinking, if corruption is rampant, and if HDI rankings are poor, the relevant countries are more likely than not to be depriving their populations of basic human rights as well as effective good governance. The observations of journalists, scholars, relief and development groups, and so on can supplement and deepen the internationally available quantitative data across many relevant dimensions.

In 2007, a published designation of the worst of the worst listed (in descending order, from most grossly repressive to highly repressive) North Korea, Turkmenistan, Burma, Zimbabwe, Belarus, Equatorial Guinea, Togo, Uzbekistan, Syria, and Tunisia as the globe's most odious regimes. ${ }^{4}$ Cuba, Iran, and Libya were other nation-states considered for inclusion in this list, but Egypt and Yemen—despite being known as states run by authoritarians, were not.

\section{NORTH KOREA AND TURKMENISTAN}

North Korea and Turkmenistan (especially under the bizarre rule from 1991 to 2006 of Saparmurad Niyazov, who called himself "Turkmenbashi" or "head of all Turkmen") were the nation-states that then exceeded and still exceed all others in their contempt for their own citizens, their cults of despotic personality, and their deprivations of the essential freedoms-even freedom from hunger. Neither place has ever exhibited respect for human or individual rights, for natural law, or for providing or permitting their inhabitants fundamental health and educational opportunities, much less regular jobs and the possibility of prosperity. Despite the exploitation of abundant reserves of natural gas in Turkmenistan and aid from South Korea and China in the case of North Korea, both populations remain poor by design and fiat, not by circumstance. Indeed, for much of the last fifty years or more, North Korea has remained "hermetically sealed." In Turkmenistan's case, Niyazov's death in 2006 should have brought about the major improvements in welfare that were promised by his successor, Gurbanguly Berdymukhammedov, but those improvements have been glacially slow in arriving. ${ }^{5}$

\section{BURMA}

Burma (Myanmar) was appropriately third on the 2007 list of gross repressors. Its ruling military junta (the State Peace and Development Committee), under Senior General Than Shwe, had long incarcerated and tortured thousands 
of political prisoners; denied all conceivable human rights; profited collectively and personally by extravagant forms of corruption; compelled conformity through brutality; eviscerated the country's once proud agricultural, economic, medical, and educational infrastructures; annulled the results of the country's only free election in 1990; imposed new artificial participatory structures; and held the nation's most prominent democrat and Nobel laureate, Aung San Suu Kyi, under house arrest for the better part of twenty years. ${ }^{6}$ But in late 2010, Than Shwe and his military associates released Daw Suu Kyi and installed a militarily dominated "elected" parliament under a juntawritten constitution. Few observers expected anything more than cosmetic changes to the repressive manner in which Burma had been ruled since 1962.

Instead, in 2011 Burma gradually emerged from its long authoritarian cocoon. Secretary of State Hillary Clinton's visit there in December, the first by such a high-ranking American official for more than fifty years, signaled Burma's possible emergence into chrysalis form. Under the presidential leadership of Thein Sein, a former general installed by the junta, and Than Shwe, more than one hundred political prisoners were released; Daw Suu Kyi was permitted to travel the country, give political speeches, and stand for election to parliament; the construction of a Chinese-sponsored hydroelectric dam on the upper Irrawaddy River was suspended; heavy censorship was lifted a little and later more significantly; and Thein Sein and his team started making the kinds of noises that conceivably augured well for the future of human rights in Burma. His regime restored freedom of assembly early in 2013.

Observers inside and outside Burma, even in the US Department of State and Beijing's Ministry of Foreign Affairs, were unsure why Thein Sein and the junta had moved to liberalize by gesture and deed, however tentatively. Some speculated that Burma's rulers were trying to diversify away from their decades-long reliance upon and warm embrace by China. Burma had been in serious danger of losing its effective national autonomy. Thein Sein sought Western approval for that reason and in order to modernize the autarkic, creaky, and long-neglected economic apparatus of the state. He and the junta may also have wanted global backing, Than Shwe and others having finally realized that Burma could take full advantage of its relatively recent finds of natural gas and petroleum, and of its enviable strategic position on the Andaman Sea (and the Indian Ocean), only by indicating a willingness not to obviate tight control over the population but to acknowledge that control could still be exercised by subtle rather than heavy-handed means. ${ }^{7}$ It was time, in other words, for Burma to come in from the cold.

Those were and are all probable reasons why Burma suddenly decided to try to leave the company of the world's most repressive states. But there is one 
more: the events of the Arab Spring may well have had a profound impact on a regime even as remote geographically as Burma from the events that took place in Tunisia, Egypt, Libya, Yemen, and Syria. As fully repressive as Than Shwe and his associates had managed to be for so long (going back to $\mathrm{Ne}$ Win's era from 1962 to 1988, and then afterward), they probably saw their future as Buddhist believers in numerology and other mystical pursuits as compromised by events on the other side of the globe. This logic, not easily refutable, probably assumed that even in a country as thoroughly controlled as Burma, the masses, long restive and periodically agitated by young monks, could again become a potent force capable of disturbing military rule and depriving the key members of the junta of their corrupt gains and family legacies. In a year that saw three heads of state indicted by the International Criminal Court (ICC) and one ousted head of state transported to The Hague for trial, Burma’s rulers may have understood their intrinsic vulnerability. We might therefore view the Burmese political dawn as an attempt to modernize and preserve authoritarian rule before it was too late. In that sense, the lessons of the Arab Spring will have been potent, formative, indeed, transformational-providing that Suu Kyi and Clinton's belief in the promised tendencies of Burma's rulers is realized in the near future.

\section{ZIMBABWE AND THE AFRICAN CASES}

Even though former president Laurent Gbagbo of Côte d'Ivoire was forcibly brought before the ICC in late 2011, Africa's long-standing tyrants, unlike Burma's, showed no signs of heeding any of the possible lessons of the Arab Spring. Mugabe and Obiang Nguema Mbasogo continued to prey upon their own constituents and citizens. Having rigged six elections systemically since 2000, Mugabe in 2013 was preparing, despite his advanced age and frail health, to ignore the democratizing strictures of his country's 2009 Government of National Unity (a South African-imposed working arrangement combining Mugabe's Zimbabwe African National Union-Patriotic Front [ZANU-PF] with the opposition Movement for Democratic Change [MDC]) and hold a national election even before a new voters' roll had been established and an independent electoral commission was in place. Bolstered by newfound wealth from alluvial diamond deposits, Mugabe (like Obiang Nguema with his vast petroleum receipts) had the wherewithal to continue to corrupt his security forces and provide patronage for crucial other indigenous power brokers.

Since 1980 Mugabe has presided over an increasingly brutal, unremittingly corrupt and corrupted, and thoroughly intolerant regime that as late as the end of 2012 was still killing and maiming its opponents, refusing to share effective 
power (in spite of the 2009 agreement) with Prime Minister Morgan Tsvangirai and his MDC team of ministers, keeping most diamond-derived revenues for Mugabe and his close associates and not giving them to the federal exchequer, and regularly reneging on promises made to South Africa and the Southern African Development Community (SADC) about advancing democratic practices within Zimbabwe. Mugabe's ZANU-PF still prevented private broadcasters from being licensed to compete against state radio and television, only reluctantly earlier in 2011 permitted an independent daily newspaper that it had bombed and shuttered in 2004 to reopen, and continued to try to take the remaining 250 (of an original 4,000) white-owned farms away from their proprietors by force (and despite SADC legal rulings to the contrary). Backed by China, Mugabe was importing small arms and other security equipment from Beijing despite UN sanctions, and sponsoring a national campaign to intimidate opponents and their followers well before any possible national election. Despite being at the head of a nominal democracy, Mugabe and his military and political associates have ruled by fear and terror since at least 2000. Even his prime minister and nominal political partner has been attacked, held on terror charges, and often ignored.

Along with Togo under Faure Gnassingbé, the son who in 2005 inherited his deprived, intimidated, and corrupted country from his father, Equatorial Guinea has been held forcefully in thrall by Obiang Nguema since 1979, when he ousted his uncle, an equally notorious and thuggish president. Obiang Nguema should be regarded as a Weberian "sultan," exercising complete power unencumbered by any rules or any commitment to ideological or other sets of values. Routine violence shapes everyday life. ${ }^{8}$ Little Equatorial Guinea, an impoverished slice of the West African mainland and a petroleum-rich offshore island, might have been ignored in this chapter and in world politics were it not for its oil—it is Africa's fourth-largest supplier to the world, especially to the United States and China — and its old-fashioned, Turkmenistanlike brutalities. Similar to tiny Togo, under dictatorship since 1978, Equatorial Guinea ranks toward the nasty end of index after index measuring the availability of human rights, the presence of corruption, the weakness of human development, the extent of misgovernance, police numbers per capita, health and welfare weaknesses, educational insufficiencies, and sheer mendacity. Whether an awareness of the reach of the Arab Spring, or the long arm of the ICC, will make any difference to one-man rule in either case is unclear (and unlikely), but in Equatorial Guinea for sure, prevailing illiteracy, lack of access to social media and the Internet, widespread poverty (despite oil), and the general inexperience of Obiang Nguema's subjects make any revolution from below unlikely. Thus, in this case, as in the cases of Zimbabwe (where possible 
ICC indictments have been investigated), Togo, Angola, Congo, the Sudan, and others, the role of possible outside intervention still remains to be explored. In these cases, is there a global responsibility to protect that needs to be considered and possibly implemented? This question will be discussed below.

\section{BELARUS AND UZBEKISTAN}

Aleksandr Lukashenko, Europe's lone tyrant and the president of anomalous Belarus, resembles Mugabe much more than Obiang Nguema or Gnassingbé in his behavior and rhetoric. His people are much more literate and wealthier per capita than those in Africa, and he has not systematically used hunger as a weapon in the Mugabe and Pol Pot manner. But he long ago perfected a strategy of repression with such force that contemporary Belarus, especially after the flawed election, arrests of opponents, and general persecution of protesters in 2011, belies its European geographical setting and its aspirations to be considered a modern state. Lukashenko's regime harasses anyone holding antithetical views, often hounding them out of private jobs. His minions respect no rights of privacy and restrict access to independent thinking and education. Judges obey the executive. Election results are manipulated and arranged. Lukashenko blusters and brutalizes like Mugabe, rides roughshod over human rights, and practices the well-learned Soviet arts of spying, intimidation, collective punishment, denial of expression and assembly freedoms, and attempts—-successfully so far-to stem the tide of participatory change that ebbs north from Ukraine and eastward from Poland and modern Europe. Even Russia, of which Belarus was once an integral part, can do little to check Lukashenko's determination to resist change and democratization.

Like the great Soviet bosses from which he learned his despotic skills, Lukashenko has advanced the arts of soft and hard repression by terrorizing his own associates and cabinet ministers, by keeping government employees on short-term contracts, by blackmailing (à la Mugabe) senior and junior officials, and by running a determinedly patrimonial state. Patronage, in other words, nakedly makes the state work, as it does in nearly all of the repressive polities discussed in this chapter. Patronage mandates dependence, as it did in Mobuto Sese Seko's Zaire/Congo. In these kinds of states there can be no nonexecutive sources of economic power or employment. Information flows must also be organized from the center, access to social media restricted (difficult on the periphery of Europe), and ideological indoctrination made into a high art. Belarus, as in Mu'ammar Gadhafi's Libya, Kim Jong Il's North Korea, and the Turkmenbashi's Turkmenistan, has its handbook of authorized ideas and aphorisms. A youth brigade has imbibed and enforced such dicta, and 
every school and workplace, Soviet- and Chinese-style, has had its ideological controller.

Lukashenko learned from his years as a Soviet regional boss. So did Islam Karimov in Uzbekistan, a cotton-growing wasteland athwart the once fabled Silk Road from inner Asia. More modern and sophisticated in many ways than Kim Jong Il, Karimov still rules supremely, deploying sufficient brutality and arbitrary capriciousness to terrorize his people and maintain his flagging regime's dominance over democratic and Islamist opponents. His regime's corruption is legendary. He and his associates (including his daughter, an heiress apparent) also benefit from Uzbekistan's strategic location on a key transport route (needed by the United States) to and from Afghanistan.

Uzbekistan has no significant institutions to keep the all-powerful executive in check. The legislature is a rubber stamp, and cabinet ministers cower in the presence of Karimov. No human rights or civil liberties are respected. Free expression was long ago banished, and sources of information, naturally, are tightly controlled and restricted. Islamists languish in prison along with several thousand political detainees. Torture is routinely employed by the security forces, journalists are beaten for "defaming the nation," and-as in so many of the worst-of-the-worst cases discussed here-citizens keep their opinions to themselves and fear the secret police. ${ }^{9}$

\section{SYRIA AND TUNISIA; EGYPT AND LIBYA}

The authors of two original studies of repression and human rights violations in Syria and Tunisia believed in 2007 that their relatively prosperous, highly literate, reasonably sophisticated authoritarian states would gradually become less brutal and more conscious of the benefits of opening their regimes to new currents of economic and political thought. ${ }^{10}$ Indeed, when the top nominees for the world's most odious nation-states were released in 2007, Tunisia's inclusion (but not Syria's) startled most observers who had not been closely following events inside the country. The global human rights community knew that President Zine al-Abidine Ben Ali's regime held numerous political prisoners, used torture, censored the media, and never tolerated dissent, but Tunisia's cultural closeness to France and its decades of relative calm had lulled most analysts of North Africa into assuming that Ben Ali's subjects were comparatively satisfied. Likewise, many still believed that President Bashar al-Assad, the young ophthalmologist who had succeeded his always scheming father in 2000, was at heart sensibly Western and would shy away from his father's many rapacious excesses. How wrong we were! 
The Syrian government, throughout the first thirteen-plus years of the twenty-first century, has curbed the right of peaceful assembly; prevented freedom of association and trade unionization; routinely practiced torture; held thousands of political prisoners, some of whom mysteriously "disappeared"; condemned dissidents as traitors after unfair trials; shut down opposition websites; and channeled nearly all economic opportunity to relatives or friends of the ruling family. Spying also became a well-practiced art. Syria's ambassador to the United States even admitted being from a "rogue" state that harbored and sponsored terrorists. ${ }^{11}$

Like Syria, Tunisia was a police state, with 150,000 police in a country of 10 million-more proportionally than Britain, France, or Germany. Elections, held periodically to appease international public opinion, were manipulated and opponents routinely brutalized. Civil society was largely prohibited, the media "asphyxiated."

Under Habib Bourguiba, Tunisia's founding president, the impress of authoritarian rule was somehow softened by his founding-father legitimacy and by the absence of overt avarice. The country also became an oasis of relative peace in a turbulent region consumed by strife next door in Algeria, and by coups in Libya and Egypt. Tunisia's comparatively high levels of development (it was the wealthiest country per capita when the worst of the worst were epitomized in 2007) also sanctified Bourguiba’s guidance. Unfortunately, Bourguiba aged and weakened; Ben Ali pushed him out of office in 1987 and proceeded to "cleanse" the country. Ben Ali eliminated Islamists and other rivals, imprisoned critics, and organized a militia of thugs to maintain control. Ben Ali's operatives also micromanaged and overregulated commerce and daily life throughout the country. Bourguiba's mild legacy had been wellobscured by late 2010 .

The cataclysm that erupted in early 2011 in Tunisia and then engulfed Egypt, Libya, the Yemen, and finally Syria demonstrated that the fires of freedom can smolder for decades within oppressed and resentful populations before they finally ignite in the kinds of conflagrations that quickly swept Ben Ali away and, for many months in 2011,2012, and 2013, provided gathering pyres for Assad and his associates. Once widespread urban-located protests commence in earnest, the experiences of the Arab Spring show, military suppression-no matter how callous toward life and injury—rarely quenches the flames. Co-optation sometimes succeeds for a time, as it did in Egypt, but a rapid embrace and legitimation of any protest is surer. Sustainable peace and harmony rarely flows from the barrels of guns, which more often provoke countervailing militant attacks, as in Syria. Thereafter, as in Tunisia, Egypt, Serbia, and Kyrgyzstan, once a crowd realizes that officers and soldiers (being 
common, poorly paid folk) are no longer loyal to the hated regime, the crowd loses its fears and surges forward. The civil war in Syria serves as an unwelcome reminder that a powerful military and a brutal government can delay this process.

That happened in all of the Arab cases. In Libya, however, the counterattack by Gadhafi and his mercenary legions might have overrun Benghazi and retained power for a time were it not for opportune intervention by NATO, Qatar, and the United States and several European countries, especially France. Thus it was that the Western decision to act boldly in Libya, backed by the Arab League and Turkey, permitted a problematic local rebellion of middleclass freedom seekers eventually to triumph decisively over Gadhafi. No one had suspected in 2010 that the autocracies of Tunisia and Egypt would soon be democratized, nor that protesters in Syria and the fractured Yemen would soon follow their Tunisian and Egyptian counterparts. Nor could Gahdafi's demise have been predicted after thirty-five years of idiosyncratic, tyrannical, one-man rule.

\section{THE FIRE NEXT TIME}

The overturning of some of the globe's more repressive regimes-notably Egypt, Libya, and Tunisia — and the indicting of heads of state (Côte d'Ivoire, Libya, and the Sudan); cabinet ministers and officials (Libya, Kenya, and the Congo); and warlords (the Congo) by the ICC means neither the end of impunity for dictators and autocrats nor the end of state-sponsored attacks on civilians. In 2013, the North Koreas, Turkmenistans, Uzbekistans, and Zimbabwes of the world remained active, and their rulers and ruling classes continued freely to abuse citizens and constituents. Eritrea, Equatorial Guinea, and Togo, led by despots, are much as they were. Cameroon, Chad, the Sudan, and Swaziland, in Africa, are almost as badly tainted. So is Laos in Southeast Asia, Kazakhstan in Central Asia, Iran in the Middle East, and Venezuela and Cuba in the Americas. China and Russia both govern arbitrarily and deny or abridge many of the normal freedoms. The list could continue, but at least Burma may have taken a turn for the better, and may conceivably improve its appalling human rights record over time. But hundreds of prisoners remain to be released, exiles remain to be welcomed home, and fully participatory elections have yet to be held.

As the Arab Spring has demonstrated so well, protests against these and any new examples of state repression must usually come from within. Some Tunisians and Egyptians had benefited from building up techniques of nonviolent resistance, learning in part from the popular uprisings in Serbia and Ukraine. ${ }^{12}$ 
And the Libyan, the Syrian, and the Yemeni protest movements would not have occurred absent success in Tunisia and Egypt. The use of new social media forms and methods was also critical to the crowd-amassing techniques in Tunisia and Egypt, later in the Yemen, and finally in sectors of Syria. In Libya, to gather and disburse information, and to mobilize defenders and attackers against Gadhafi and his legions, demanded the imaginative deployment of social media and text messaging. Revolutionary achievements depend now on cell towers and strong signals more than ideology and oratory.

Outsiders can also play a strong role in ensuring the triumph of internal insurrections. In the Yemen, Saudi and United Arab Emirates (UAE) diplomats played a brokering role between President Ali Abdullah Saleh and the various protest movements. The Saudis and the United States also understood more than others, and often more than the Saleh government, where protesters were active and where they were not. Pressure from the Arab League, its sanctions, and European Union sanctions (and refusals to purchase petroleum), were all decisive in weakening the Assad grip on Syria. Turkey's antagonism, barriers to cross-border trade, and willingness to harbor anti-Assad militants were also critical. But in Libya, the people's military victory over Gadhafi and his army could not have happened without the intelligence of regime troop and air movements obtained by NATO and shared with the Libyan transitional forces. The European-and-American blockade of Tripoli and other Gadhaficontrolled ports was also significant, as was the supply of arms and decisive military equipment to the insurgents by France, Qatar, the United States, and others. Some NATO special forces may also have deployed covertly on the ground.

This much is obvious: Libya could not have been freed so readily from Gadhafi's stifling grip without assistance and strong support from the Arab League and the West. But Libya is a very special case. Gadhafi had offended his fellow Arab rulers and most of the powerful nations belonging to the Arab League. After Ben Ali's quick exit from Tunisia and President Hosni Mubarak's ouster from Egypt, Gadhafi's loss of legitimacy was swift. No one, except a few sub-Saharan African client states, saw any virtue in his continued suzerainty. His capture and death, awkward and inhumane as they were, seemed a fit end.

Absent dramatic internal rumblings in Belarus, Turkmenistan, and Uzbekistan, the West is hardly poised to intervene there on behalf of human rights. Only if Russia, in whose neighborhood those states lie, itself decided to champion the oppressed in some or all of those countries could insurgents rely on assistance from either the near- or the far-abroad. Likewise, there is no appetite to upset China by moving against nuclear-armed North Korea, even during times of widespread regime-induced starvation. Even with regard to 
Zimbabwe, where an aging ruler has long defied the preferences of his neighbors and perpetuated a despotic regime that has lost all international credibility and local legitimacy, there is no appetite for externally induced regime change or ruler removal. Only a wave of impermissible atrocities, as Gadhafi was perpetuating in Libya, might move powerful neighbors or outsiders in these and similar cases to act in time, or at all.

\section{WHAT IS TO BE DONE?}

World order may say "Never again" to another Rwandan genocide, but smallscale mass killings are common from Thailand to Ecuador, Mugabe still uses hunger as a weapon against his own people, and President Omar al-Bashir's aircraft strafe non-Arab sections in the south of the newly truncated Sudan and raze the dwellings of opponents in the Blue Nile and Nuba Mountain districts. Can anything now be done in similar weak, failed, and collapsed states to protect the weak and curtail those countries that prey harmfully on their own citizens?

The inhabitants of failed states like Afghanistan, Congo (Kinshasa), and the Sudan are particularly at risk. By definition, such states have lost the monopoly of violence; they are at war with themselves. Such failed and a handful of very weak states are so internally fractured, so illegitimate in the eyes of large numbers of their citizens, and so corrupt that they no longer perform for their inhabitants. That is, their levels of governance are quantifiably low. ${ }^{13}$ It follows that such states demonstrate little respect for fundamental human rights. They prefer the law of the jungle to the rule of law. Most of their human development responsibilities are honored in the breach. Economically, they are deficient, and in most cases (other than once oil-rich Sudan) they do not grow rapidly, leaving their populations in poverty. In many of these states, nonstate actors (warlords) proliferate, and killings, rapes, and other abuses are perpetrated by both the state and its opponents.

No regional or subregional institutions exist to right failed states or the collapsed state of Somalia. Nor are there any effective mechanisms available to prevent weak states from becoming failed states in the manner of Côte d'Ivoire in 2000-2001. British paratroopers are not moving in to restore security and order as they did in Sierra Leone in 2000, as France did in Mali in 2013, as Syria did when Lebanon was a failed state in the 1970s, and as Russia did in Tajikistan in the 1990s. Sometimes the UN has mounted an effective peace enforcement operation, as in Liberia from 2003. But most UN missions, as in Darfur or the eastern Congo, have been holding operations. They have sometimes lacked the mandates, sometimes the troops, and sometimes the political will to prevent failed or weak states from pummeling their own, or permitting 
warlords to do the same. (When the M23 rebel movement captured Goma in 2012, UN troops watched.) In Somalia, the African Union peacekeeping detachment in Mogadishu was for much of 2010 and 2011 too weak to overcome al-Shabaab and project any power beyond the capital city. Only when Ethiopian, Kenyan, and Ugandan troops entered the battle scene in 2012 and 2013 could al-Shabaab be ousted from Kismaayo, Baidoa, and other strategic towns, and a measure of peace be restored to Mogadishu.

Knowing that international peace enforcement and peacekeeping interventions are often ineffective, slow, off the mark, indecisive, and underresourced, coalitions of the willing or unilateral actions have often proved productive. Syria into Lebanon and Russia into Tajikistan have already been noted. Of equal significance, Tanzanian troops ousted Idi Amin from cruelly run Uganda in 1979. Directed by the Economic Community of West African States (ECOWAS), a predominantly Nigerian task force dampened violence in Liberia after 1990. Australia sent soldiers and sailors twice to support peace processes in the Solomon Islands in 2003 and 2006. They were also active in Timor-Leste in 1999, but at the request of the UN. A renegade Lesotho was corralled by South African and Botswanan soldiers in 1998-1999, but at the nominal behest of the SADC. Ethiopian forces eliminated the hegemony in southern Somalia of the Union of Islamic Courts in 2006. It is evident from these and other scattered examples that interventions for legitimate peace-creating purposes have their place in ending despotism and removing abusers from power. Whereas national violators of human rights have traditionally been immune from direct global sanctions because of a misplaced sense of sovereign immunity, their excesses occasionally provoke hard-edged martial responses from powerful neighbors and near-neighbors or from groups of them. After ousting dictators or stanching civil wars, those "invasions" have enhanced the quality of life and education and health opportunities in former despotisms. At the very least, they have prevented tyrants from continuing to abuse their populations.

But it would be unwise to rely on such direct initiatives to safeguard vulnerable peoples across the globe. Thailand never considered saving the Cambodians under Pol Pot. Its neighbors never thought before late 2012 of intervening in the Central African Empire. Nor did France. SADC and South Africa are not crossing national frontiers to impose justice on Zimbabwe. Nor is massive Nigeria prepared to right hideous wrongs in nearby Equatorial Guinea. The Sudan is sovereign within its borders, despite systemic attacks on dissenting peoples along its new southern frontier and in Darfur. The Laotian government is allowed to violate the human rights of its citizens. No one is curbing excesses in Uzbekistan or Kazakhstan, or even in Turkmenistan. Until an indigenous freedom movement arose in Libya, or in Tunisia, outsiders were 
hardly anxious to intervene. Nor, one assumes, did any powerful state even contemplate such adventures.

\section{RESPONSIBILITY TO PROTECT}

The new responsibility-to-protect norm, discussed by the United Nations in 2005 and again in 2009, but never formally accepted or ratified, provides an umbrella rationale under which world order should in theory rescue citizens in countries at risk and intervene in countries that have crossed some red line between general nastiness and wholesale abuse. The latter category could legitimately be restricted, say, to situations where states and rulers are committing crimes against humanity according to The Hague Conventions of 1899 and 1907, the statute of the Nuremberg Tribunal, the 1948 Genocide Convention, the Geneva Conventions of 1949, the additional protocols to the Geneva Conventions in 1977, the statutes of the International Tribunals for Former Yugoslavia and Rwanda, and the 1998 Rome Statute of the International Criminal Court. These instruments regulate human conduct during war and prohibit genocide, ethnic cleansing, enumerated specific crimes against humanity, and all manner of mass and nonmass atrocities. Although imprecise, these prohibitions compose an overarching norm that should be sufficiently robust to hinder renewed attacks on civilians or groups. ${ }^{14}$ Certainly the ICC and the several tribunals can base their own prosecutions (and subsequent judgments) on the various violations of appropriate and decent conduct that are enumerated in the conventions and statutes.

By at least some readings of the Genocide Convention, the UN and member states are "obligated" to prevent and suppress acts of genocide. ${ }^{15}$ But the means to obligate the obligation are not yet available in world order. Nor are thresholds easily defined for genocide or ethnic cleansing, even in those heinous situations where it appears obvious that there has been or that there is about to unfold a "mass destruction" of a human collectivity.

The Rome Statute is much more precise: a crime against humanity is any systematic attack against civilians that includes murder, extermination, enslavement, forcible transfers, imprisonment or severe deprivations of physical liberties, torture, rape, or sexual slavery. Crimes against humanity are always "large" in scale. There is some thought that crimes against humanity must also be premeditated and willful of intent. Because the provisions of the Rome Statute were written for interstate rather than intrastate wars, the more prevalent form of combat in this century, they were not meant to apply to riots and sporadic acts of violence, but they were and are intended to cover protracted armed civil conflicts between governments and nonstate actors. 
Individual rulers and leaders are, according to the Rome Statute, held responsible for crimes against humanity perpetrated by a country's armed battalions or soldiers. The mistreatment of civilians in the Congo, say, is fully covered. In 2012 and 2013, the application of these provisions was being tested in The Hague by both prosecutors and defense attorneys for Gbagbo and other alleged wrongdoers. These several cases brought by the ICC, and earlier trials in The Hague and Arusha before the Yugoslavian and Rwandan panels, presumed that the act of bringing perpetrators of crimes against humanity to justice would ultimately deter others-that the punishment of those who authorized ethnic cleansing or mass-atrocity crimes would cause other potential perpetrators to hesitate before they ordered such crimes against innocent civilians within their own countries.

Whether or not this is in fact occurring-whether or not the malevolent mailed fist of tyranny is being stayed - is difficult to determine at this early stage in the life of the ICC. Possibly in a decade there will be sufficient evidence to demonstrate the efficacy of the ICC, and of its prosecutions. Conceivably, too, it will be the fear of being investigated by prosecutorial teams from the ICC that will deter potential abusers of power. In the Kenyan cases, for example, the suspicion that powerful politicians brought about ethnic attacks in 2008 may chill other equally mendacious political actors in Kenya and in similar African countries in the near future. That Gbagbo was hauled away to The Hague may conceivably compel would-be despots (hardly existing ones) to behave more cautiously and less perniciously. Yet, even if it does, only 139 states have signed the Rome Statute. For nonsignatories (like Libya and Zimbabwe), the ICC cannot indict individuals until such time as the UN Security Council, hoping for Chinese and Russian abstentions rather than vetoes, votes to refer a country case to The Hague. The UN Security Council did so in the case of Libya, but has not yet been asked to do so in the case of Zimbabwe.

This question of sovereignty and the presumed right (according to serial abusers) to rule despotically within a country stands squarely in the way of justice. Moreover, even if we choose to believe that indictments, prosecutions, and judgments curb future war crimes, there will never be sufficient investigators, courts, and funds to combat atrocities through the legal system, domestic and international. Moreover, courts act after the fact. Thus there has long been a need to prevent abuses against civilians by their rulers in real time. World order should have reacted immediately, for example, when the first intimations arrived of a possible genocide in Rwanda. ${ }^{16}$ When the Mugabe regime permitted its people to starve in the millions from 2003 through 2008, world order responses should have been triggered. ${ }^{17}$ When Belarus or Syria 
shoots protesters in the streets, again and again, or when Bahrain abuses its Shia majority, there should be some means of hindering the perpetuation and the proliferation of such crimes against humanity. ${ }^{18}$

In 2001, a Canadian-sponsored international commission proposed that the world order and every nation-state had a "responsibility to protect" its own citizens from grievous harm. ${ }^{19}$ The physical and psychological safety of inhabitants of a country were more important than sovereignty, and overcame claims of sovereignty. Indeed, the commission asserted an overriding right of humanitarian intervention. Violence within a state that shocked "the conscience of mankind" should trigger outside military intervention. Certainly large-scale loss of life or large-scale ethnic cleansing provided "just cause" for military intervention. ("Large-scale" was not defined.)

In 2005, a UN World Summit accepted the R2P norm. Between 2001 and 2005 there had been an avalanche of deaths in Congo and the Sudan (Darfur), thus concentrating the minds of the delegates. The Outcome Document of the Summit obligated world order and individual states to protect groups in harm's way and, if necessary and despite hitherto-sacrosanct borders, to rescue them. The R2P norm of 2005 charged each state with the protection of its citizens. The member states at the summit further promised to assist populations under stress even before attacks begin. Thus the intent of the Outcome Document could be read as a rejection that sovereignty (as construed since the Congress of Westphalia) shielded leaders and regimes from international concern. ${ }^{20}$ But in 2005 the member states did not determine what the UN itself should do.

Nor did they in 2009, when the UN secretary-general and his special preparatory task force attempted to negotiate an operationalization of the R2P norm. How should the UN, in all of its component parts, be mobilized to protect peoples at risk? That essential question was never answered in precise or implementable terms, the proponents of extending the reach of R2P repeatedly being rebuffed by those defending sovereign immunity. Burma, Cuba, Nicaragua, North Korea, the Sudan, Venezuela, and Zimbabwe led the charge against R2P. Russia and China were not anxious to see any change in existing modalities. The strongest backers of converting R2P from a concept into a norm were a clutch of African nations, including South Africa and Nigeria, most South American countries, the nation-states of the developed world, Jordan, Morocco, and Qatar. ${ }^{21}$ But, in 2013, R2P remains an ideal, a set of principles, and an unarticulated premise instead of a norm (unlike the anti-land-mine norm, converted into a treaty) that mandates the protection of civil populations when they are abused by the regimes under which they are governed. 
Gareth Evans, one of the principal inventors and articulators of R2P, argues that the norm should not be thought of as a remedy for human security issues generally. It is not "about solving all the world's problems." Rather, it should be applied in those special cases where mass-atrocity crimes are "clearly being committed," where such crimes are "about to be committed," or where there is a serious risk that such crimes will be committed in the foreseeable future "unless effective preventive action is taken." ${ }^{22}$ Evans and other supporters of $\mathrm{R} 2 \mathrm{P}$ indeed prefer a narrow construction of the norm for fear that any broader application would make it incoherent, and its application haphazard.

In fact, R2P provided a justification for outside intervention in Libya; certainly the US National Security Council persuaded Secretary of State Hillary Clinton and President Obama that the West and the United States were obliged to protect those in Benghazi and eastern Libya who were about to be smashed by Gadhafi and his followers in March 2011. Intervention at that moment saved the lives of many insurgents and, by engaging NATO fully on the side of rebels, turned the tide of the war.

Less dramatically but just as powerfully, former UN secretary-general Kofi Annan employed the concept of R2P in Kenya in 2008 to intervene morally, first to end postelection tit-for-tat killings of ethnic opponents and then to impose a coalition government on those on either side of the ethnic and political divide. Annan, by stature and experience representing world order, could make R2P work. So could French troops and UN interposition in Côte d'Ivoire provide physical and diplomatic cover to Alassane Ouattara, winner of the 2010 presidential election, and ultimately legitimize the removal of Laurent Gbagbo after he refused to give up the presidency. In 2013, France's forcible intervention against al-Qaeda-linked jihadists who had occupied and repressed northern Mali was critical in protecting and liberating indigenous Malians from the depredations of Islamists. In all four cases, there was no Security Council declaration of an R2P emergency. Instead, in keeping with the amorphous and ambiguous normative terrain occupied by R2P, the force of R2P was deployed when and how it could be most influential. ${ }^{23}$

Note, however, that R2P was never enunciated or even alluded to when protesters took to the Tahrir Squares in Tunis and Cairo, when Yemeni soldiers shot protesting students in Sanaa and Taiz, or when Bahrainis shouted against Emir Hamad bin Isa al-Khalifa in Pearl Square. Nor, as conditions worsened by the day, month after month, did world order consciously accept any compelling obligation under R2P to forcibly stop the killings in Homs, Hama, Aleppo, and other Syrian cities, or even to impose a no-fly zone as they had in Saddam-afflicted Kurdistan. 
Clearly the world order, the UN system, the G7, the G20, and regional and subregional organizations know what to do. They all know how to intervene to save lives, but not exactly when, or with what rationale. Sarah Sewall argues that "the United States and the international community should proactively respond to the outbreak of widespread civil massacres with military force as well as other tools of national and international power." She prefers early interference in order to obviate the escalation of state-directed violence against disadvantaged citizens. Acting early is always better than acting late, or not at all, and the costs are far lower. Lives are saved, too. ${ }^{24}$

\section{CURRENT REMEDIES}

Given that Sewall's doctrine is unlikely ever to be embraced by the United Nations, and by the EU and the United States only in limited and very special circumstances (Libya), populations in failed and collapsed states, in weak states, and certainly in the worst of the globe's polities will remain at risk. Mugabe wannabes will continue to kill and maim their opponents and subject large numbers to the trials of hunger. Women of the eastern Congo will continue to be raped, forty a day according to one report. ${ }^{25}$ Burma's military will bomb Kachin and Shan ethnic strongholds, the Chinese will harass and imprison Tibetans and Uighurs, and Uzbekistan will chain its Islamist prisoners ever more tightly.

The world order has still not managed to create consistent tools to curb dictators, to impose civilized methods on primitive and recalcitrant regimes, or to persuade its most odious members to embrace humanity and tread the democratic paths of tolerance and civility. Nor has the UN itself, or most of its members, ever found a voice with which to condemn and shame those who are the worst of the worst. Redress will therefore come episodically and painfully, primarily from within.

\section{NOTES}

1. For precise rather than loose definitions of what constitutes a weak, a failed, or a collapsed state, see Robert I. Rotberg, "The Failure and Collapse of NationStates: Breakdown, Prevention, and Repair," in When States Fail: Causes and Consequences, ed. Robert I. Rotberg (Princeton, NJ: Princeton University Press, 2004), $1-50$.

2. This section, and particularly the checklist, draws heavily on Robert I. Rotberg, "Repressive, Aggressive, and Rogue Nation-States: How Odious, How 
Dangerous?" in Worst of the Worst: Dealing with Repressive and Rogue Nations, ed. Robert I. Rotberg (Washington, DC: Brookings, 2007), 1-39, esp. 5.

3. For a discussion of data methods, see ibid., 4-6.

4. Ibid., 13-34.

5. See Marcus Noland, "North Korea: The Tyranny of Deprivation," in Rotberg, Worst of the Worst, 89-93.

6. See Benedict Rogers, Than Shwe: Unmasking Burma's Tyrant (Chiang Mai, Thailand: Silkworm Books, 2010), 95-99; and Emma Larkin, Everything Is Broken: A Tale of Catastrophe in Burma (New York: Penguin, 2010), 119, 130, 160-63.

7. But see Bertil Lintner, "Realpolitik and the Myanmar Spring," Foreign Policy, November 30, 2011, http://www.foreignpolicy.com/articles/2011/11/30/ democracy_myanmar_china_clinton.

8. Rotberg, "Repressive, Aggressive," 25; John R. Heilbrunn, "Equatorial Guinea and Togo: What Price Repression?” in Rotberg, Worst of the Worst, 223-46.

9. For details, see Martha Brill Olcott, "Uzbekistan: A Decaying Dictatorship Withdrawn from the West," in Rotberg, Worst of the Worst, 250-68.

10. David W. Lesch, "Assessing Repression in Syria," in Rotberg, Worst of the Worst, 269-99; and Clement Henry, “Tunisia's 'Sweet Little' Regime," in Rotberg, Worst of the Worst, 300-324.

11. Thom Shanker, "For Syria's Voice in U.S., Isolation but Not Silence," New York Times, July 29, 2006.

12. See Erica Chenoweth and Maria J. Stephan, Why Civil Resistance Works: The Strategic Logic of Nonviolent Conflict (New York: Columbia University Press, 2011).

13. See definitions of governance and detailed statistics in Robert I. Rotberg and Rachel M. Gisselquist, Strengthening African Governance: The Index of African Governance, 2009 (Cambridge, MA: Kennedy School of Government, Harvard University; and World Peace Foundation, 2009).

14. See Robert I. Rotberg, "Deterring Mass Atrocity Crimes: The Cause of Our Era," in Mass Atrocity Crimes: Preventing Future Outrages, ed. Robert I. Rotberg (Washington, DC: Brookings, 2010), 1-24.

15. For definitions, see Dan Kuwali, "Old Crimes, New Paradigms: Preventing Mass Atrocity Crimes," in Rotberg, Mass Atrocity Crimes, 25-54. Also see Rotberg, "Deterring Mass Atrocity Crimes," 4, for the definition of "ethnic cleansing."

16. See Allison L. Des Forges, "Making Noise Effectively: Lessons from the Rwandan Catastrophe," in Vigilance and Vengeance: NGOs Preventing Ethnic Conflict in Divided Societies, ed. Robert I. Rotberg (Cambridge, MA: World Peace Foundation, 1996), 213-34.

17. Robert I. Rotberg, "Winning the African Prize for Repression: Zimbabwe," in Rotberg, Worst of the Worst, 177; Rotberg, Beyond Mugabe: Preparing for Zimbabwe's Transition (Washington, DC: Center for Strategic and International Studies, 2011). 
18. See Mahmoud Cherif Bassiouni, Report of the Bahrain Independent Commission of Inquiry (Manama: Bahrain Independent Commission of Inquiry, November 23, 2011).

19. The Report of the International Commission on Intervention and State Sovereignty, published as Responsibility to Protect (Ottawa: International Development Research Centre, 2001). See also Gareth Evans, The Responsibility to Protect: Ending Mass Atrocity Crimes Once and for All (Washington, DC: Brookings, 2008), 38-48.

20. See Matthew C. Waxman, Intervention to Stop Genocide and Mass Atrocities (New York: Council on Foreign Relations, 2009), 10.

21. Claire Applegarth and Andrew Block, "Acting against Atrocities: A Strategy for Supporters of R2P," in Rotberg, Mass Atrocity Crimes, 128-29.

22. Gareth Evans, "Implementing the Responsibility to Protect: The Need to Build on the 2005 Consensus" (speech at the UN General Assembly, New York City, July 23, 2009), available at www.gevans.org/speeches.

23. For Kenya, see Daniel Branch, Kenya: Between Hope and Despair, 19632011 (New Haven, CT: Yale University Press, 2011), 277-84.

24. Sarah Sewall, "From Prevention to Response: Using Military Force to Oppose Mass Atrocities," in Rotberg, Mass Atrocity Crimes, 160.

25. Amber Peterman, Tia Palermo, and Caryn Bredenkamp, "Estimates and Determinants of Sexual Violence Against Women in the Democratic Republic of Congo," American Journal of Public Health 101, no. 6 (2011): 1060-67.

\section{REFERENCES}

Applegarth, Claire, and Andrew Block. "Acting against Atrocities: A Strategy for Supporters of R2P." In Rotberg, Mass Atrocity Crimes, 128-58.

Bassiouni, Mahmoud Cherif. Report of the Bahrain Independent Commission of Inquiry. Manama: Bahrain Independent Commission of Inquiry, November 23, 2011.

Branch, Daniel. Kenya: Between Hope and Despair, 1963-2011. New Haven, CT: Yale University Press, 2011.

Chenoweth, Erica, and Maria J. Stephan. Why Civil Resistance Works: The Strategic Logic of Nonviolent Conflict. New York: Columbia University Press, 2011.

Des Forges, Allison L. "Making Noise Effectively: Lessons from the Rwandan Catastrophe." In Rotberg, Vigilance and Vengeance, 213-34.

Evans, Gareth. "Implementing the Responsibility to Protect: The Need to Build on the 2005 Consensus." Speech at the UN General Assembly, New York City, July 23, 2009. Available at www.gevans.org/speeches.

- The Responsibility to Protect: Ending Mass Atrocity Crimes Once and for All. Washington, DC: Brookings, 2008. 
Heilbrunn, John R. "Equatorial Guinea and Togo: What Price Repression?" In Rotberg, Worst of the Worst, 223-46.

Henry, Clement. "Tunisia's 'Sweet Little' Regime.” In Rotberg, Worst of the Worst, 300-324.

International Commission on Intervention and State Sovereignty. Responsibility to Protect. Ottawa: International Development Research Centre, 2001. http:// responsibilitytoprotect.org/ICISS\%20Report.pdf.

Kuwali, Dan. "Old Crimes, New Paradigms: Preventing Mass Atrocity Crimes." In Rotberg, Mass Atrocity Crimes, 25-54.

Larkin, Emma. Everything Is Broken: A Tale of Catastrophe in Burma. New York: Penguin, 2010.

Lesch, David W. "Assessing Repression in Syria." In Rotberg, Worst of the Worst, 269-99.

Lintner, Bertil. "Realpolitik and the Myanmar Spring." Foreign Policy, November 30, 2011. http://www.foreignpolicy.com/articles/2011/11/30/democracy_ myanmar_china_clinton.

Noland, Marcus. "North Korea: The Tyranny of Deprivation.” In Rotberg, Worst of the Worst, 89-114.

Olcott, Martha Brill. "Uzbekistan: A Decaying Dictatorship Withdrawn from the West." In Rotberg, Worst of the Worst, 250-68.

Peterman, Amber, Tia Palermo, and Caryn Bredenkamp. "Estimates and Determinants of Sexual Violence Against Women in the Democratic Republic of Congo." American Journal of Public Health 101, no. 6 (2011): 1060-67.

Rogers, Benedict. Than Shwe: Unmasking Burma's Tyrant. Chiang Mai, Thailand: Silkworm Books, 2010.

Rotberg, Robert I. Beyond Mugabe: Preparing for Zimbabwe's Transition. Washington, DC: Center for Strategic and International Studies, 2011.

- "Deterring Mass Atrocity Crimes: The Cause of Our Era." In Rotberg, Mass Atrocity Crimes, 1-24.

- "The Failure and Collapse of Nation-States: Breakdown, Prevention, and Repair." In When States Fail: Causes and Consequences, edited by Robert I. Rotberg, 1-50. Princeton, NJ: Princeton University Press, 2004.

—, ed. Mass Atrocity Crimes: Preventing Future Outrages. Washington, DC: Brookings, 2010.

—. "Repressive, Aggressive, and Rogue Nation-States: How Odious, How Dangerous?” In Rotberg, Worst of the Worst, 1-39.

- ed. Vigilance and Vengeance: NGOs Preventing Ethnic Conflict in Divided Societies. Cambridge, MA: World Peace Foundation, 1996.

- "Winning the African Prize for Repression: Zimbabwe." In Rotberg, Worst of the Worst, 166-92.

ington, DC: Brookings, 2007. 
Rotberg, Robert I., and Rachel M. Gisselquist. Strengthening African Governance: The Index of African Governance, 2009. Cambridge, MA: Kennedy School of Government, Harvard University; and World Peace Foundation, 2009.

Sewall, Sarah. "From Prevention to Response: Using Military Force to Oppose Mass Atrocities." In Rotberg, Mass Atrocity Crimes, 159-74.

Shanker, Thom. "For Syria's Voice in U.S., Isolation but Not Silence." New York Times, July 29, 2006.

Waxman, Matthew C. Intervention to Stop Genocide and Mass Atrocities. New York: Council on Foreign Relations, 2009. 


\title{
CHAPTER 7
}

\section{State Collapse and Local Response in Somalia}

\author{
Ken Menkhaus
}

Somalia has been the site of an extraordinary political drama. For more than twenty years, the central government there has been in a state of complete collapse. An estimated eight million people have been living without a state for two decades. For Somalis under the age of thirty, or 73 percent of the total population, state collapse is the only political order they have ever known. If and when a posttransition government is established, most of the Somali population will be learning for the first time what a central government can and should do.

In 2011, a transitional federal government (TFG) existed in Somalia, but mainly on paper. Most of the capital of Mogadishu is divided into militia fiefdoms, and the countryside is a mosaic of different local authorities, including the now-weakened jihadi group al-Shabaab. The TFG oversaw the transition and selection process of a new federal government that formed in August 2012. What is important to remember is that a declaration of a posttransition government has not changed the fact that most of the country will remain beyond the reach of the new government for some time to come. Most of the country and parts of the capital itself will remain under the de facto control of autonomous strongmen, self-proclaimed regional states, clan militias, and al-Shabaab.

What this means is that most local communities in Somalia will remain on their own when it comes to basic services associated with the state, including security, law and order, market regulation, and basic common goods. Somalis are not alone in this predicament. Many tens of millions of people in fragile 
or failed states live more or less beyond the meaningful reach of a central government.

Journalists and analysts who cover these "stateless" zones often gravitate toward one of two camps. One depicts areas of state collapse as sites of "Mad Max anarchy," where warlords and armed criminals rule and prey on helpless citizens. The second school of thought depicts these areas through a libertarian lens, celebrating the unfettered entrepreneurism of local businesses, the privatization of everything from seaports to passports, and the freedom from government taxes and regulations.

There is a grain of truth in both of these perspectives on life in a collapsed state, but both are also gross distortions of the reality on the ground. Living in a collapsed state is neither a nightmare of Mad Max anarchy nor a libertarian paradise. It is instead a messy and complex operating environment for families and businesses, but one in which they learn to cope and adapt. And it is one in which communities quickly construct a variety of systems and informal political orders to provide for themselves some degree of law and order - what some of us have termed "governance without government."

What does this "governance without government" look like in Somalia, and what role might it play in the country's ongoing task of state revival?

\section{GOVERNANCE WITHOUT GOVERNMENT}

The sudden collapse of the Somali central government in January 1991 was accompanied by uncontrolled predatory militia violence that produced massive displacement and casualties, and a famine that claimed 240,000 lives. Teenage gunmen terrorized communities, and traditional authorities were unable to control them. Not surprisingly, most observers concluded that Somalia constituted a zone of Mad Max anarchy.

But in a relatively short period of time, local communities began to forge informal arrangements to provide some degree of predictability and security for themselves. That they were so quick to do so serves as a reminder of a powerful observation about zones of state failure: in many cases, people and communities are not passive victims in the face of state collapse and criminal violence. The result was that by 1995, when the illfated United Nations peace-enforcement mission left Somalia, a patchwork quilt of local political orders had emerged in neighborhoods, towns, and villages across much of the country. This assortment of local arrangements was hardly ideal - it was fluid, patchy, variable in capacity and legitimacy, chronically contested, vulnerable to armed spoilers, and illiberal in the kind of justice it dispensed. But these local arrangements have endured 
and evolved over the past fifteen years and in some cases have provided local communities with better basic governance than exists in neighboring states. It is commonly believed that the capacity of Somali communities to reassert some degree of law and order was due to the revival of traditional authority and customary law. It is true that clan elders succeeded in regaining some control over their kinsmen, and that "xeer," or customary law, remains the principal mechanism for resolving disputes, compensating victims of crime, and managing interclan relations. But the rise of informal governance in Somalia was more complex than just a revival of customary law. Clan elders could not have done this on their own.

The assertion of order involved a hybrid coalition of actors with a shared interest in establishing basic security and rule of law. These other actors included professionals, who guided elders through the new and complex problems that customary law could not address; Muslim clerics, who set up local, clan-based sharia courts as a complement to customary law; women's market-vendor groups and other civic organizations that were able to mobilize populations, reach across conflict lines, and shame militiamen; aspiring local politicians, who saw opportunities to advance their own ambitions by supporting local governance; and an emerging business class, which underwrote local sharia courts and police forces in order to provide for themselves a more conducive commercial environment. Potential spoilers, including armed gangs and militias, were sometimes co-opted as deputized local police or protection forces. This was not always possible, but in many instances young gunmen were happy to take up a more respectable, salaried job in a local security unit rather than face the dangers and stigma of operating a militia checkpoint.

In other cases, law and order was established by militia leaders who, in order to advance their economic or political ambitions, saw benefits in recasting themselves as "governors" rather than "colonels." The crudest of these polities were little more than warlord fiefdoms, a reminder that the legitimacy of informal governance systems can range widely from one location to the next.

The capacity of Somalia's local polities in the post-1995 period also varied significantly. Some were little more than protection rackets, providing basic security for a fee. Others provided more-robust rule of law and dispute mediation-typically parties to a dispute were afforded the choice of customary or sharia law, so the two were not seen as rival systems. Almost everywhere, clan elders were relied upon to manage endemic land disputes and provide a critical role as witnesses to property sales, acting as guarantors that deeds were legitimate. This was a very important role for the emerging private sector. In a few places, informal governance systems pushed beyond security and rule of law into more advanced governance roles. In several towns, committees of 
clan elders regulated the allocation of all contracts, employment, and rentals that international aid agencies introduced into the area, as a means of ensuring proportional allocation by clan and preventing conflict over resources. Many towns organized fund-raising and volunteer labor in order to provide a public good that, due to its cost, constituted a "collective action" problem, such as a damaged road or bridge. In other locations, committees of clan elders served as regulatory bodies to determine, for instance, the fair price of electricity sold by a local business group that operated a generator and ran lines to customers' homes.

This "regulatory commission" role pointed to the fact that the private sector was stepping in to provide many of the services normally associated with the state. In Mogadishu, private entrepreneurs ran electrical grids and underground piped-water systems to paying customers, operated private airports and seaports, provided basic and advanced medical services, and established private schools. The most advanced and inexpensive cellular telecommunication system in Africa arose in Somalia in the late 1990s, thanks to competing businesses. And Somalia's numerous remittance companies provided trusted, efficient money transfers and other quasi-banking roles. A small group of businesspeople also assumed control of core sovereign roles of the state, such as control over the exchange rate and circulation of Somali shillings.

Local nonprofit groups, many underwritten by Somalia's large diaspora, also competed to provide schools and health services. This included some of the largest universities in Somalia, such as the University of Mogadishu and the Somali Institute of Management and Administration Development. Local civil groups, including NGOs, self-help groups, women's market-vendor groups, and, above all, mosques, continued to serve as a critical source of basic welfare for families in need. This was a role the Somali government had never been able to play prior to the 1990 s.

In a number of towns, these governance arrangements were formalized into municipalities, some of which constituted the most effective and impressive form of administration in the country. Mayors had the advantage of presiding over a political unit that, unlike informal governance, was recognizable to international donors and so could tap modest amounts of foreign assistance to help underwrite delivery of services including road repair, water systems, and urban planning. Towns also tended to be sites of residence and business for multiple clans, offering greater opportunities for functional collaboration on matters of shared interest.

In a few cases, local governance in the 1995-2006 period grew to an even larger scale in the form of regional state administrations. The biggest and most successful of these, Somaliland, is a secessionist state with a fully developed 
government, parliament, court system, and security sector operating on a modest annual budget of about $\$ 35$ million. In the northeast of the country, the nonsecessionist state of Puntland emerged in the late 1990s. Like Somaliland, it benefits from customs revenues on an active seaport and has established a modestly effective formal administration and police force.

These local governance arrangements are quite complex, in a constant state of flux, and hence very challenging for Somalis to navigate. Working effectively in this environment, whether as a businessperson, elder, politician, or civil leader, requires a level of political acumen that outsiders often fail to appreciate.

\section{RECENT CHALLENGES}

Since 2006, armed hostilities, foreign military occupation, jihadism, internal displacement, and humanitarian crises have taken a toll on local governance systems. Civil society leaders across the board, from prominent elders to educators to human rights advocates, have been hammered by political violence. Political threats and assassinations have become epidemic in scale, leading to the death or exodus of many of the most powerful social voices in local governance. In the past year, growing numbers of civil society leaders began returning to Somalia after seeking refuge abroad, but the once powerful civic networks that constituted such an important part of local political orders have been weakened. Clan elders have also been subjected to new levels of political manipulation in national consultations and nomination processes, eroding their credibility among the public. Some business leaders divested from wartorn Mogadishu and invested instead in neighboring Kenya, while those who remained in Somalia have had to pay taxes to either al-Shabaab, the transitional federal government, or both, leaving them less willing and less able to underwrite informal authorities as well.

\section{INFORMAL GOVERNANCE UNDER AL-SHABAAB}

By 2008, most of southern Somalia had fallen under the control of the radical Islamist group al-Shabaab. The group imposed direct administrative oversight in the largest urban areas under its control, such as Kismaayo and portions of Mogadishu, but lacked the means to create a "state within a state" across all of southern Somalia. Instead, it outsourced day-to-day governance to existing authorities, replaced elders and other local authorities deemed untrustworthy, and posted young al-Shabaab militia in villages to monitor local authorities. One area of governance al-Shabaab did retain for itself was the imposition of 
law and order. Criminals, as well as individuals accused of moral wrongdoing such as adultery, faced severe punishment under al-Shabaab, including amputations and stonings.

Clan elders and other local authorities living under al-Shabaab's rule were and remain marginalized and constrained, but by many accounts they have still been able to articulate community grievances to al-Shabaab commanders and exercise some influence over militia leaders. This was most in evidence during the worsening humanitarian crisis that culminated in the 2011 famine. Al-Shabaab leaders with clan constituencies in their areas of control came under sustained pressure to allow international food-aid deliveries, producing serious tensions within al-Shabaab.

In "liberated areas" - zones where African Union peacekeepers, Kenyan and Ethiopian forces, and their local proxies have pushed out al-Shabaabsystems of informal governance have been slow to bounce back, in part because the armed militias that have replaced al-Shabaab often come from other clans and regions, and are therefore beyond local control. But local authorities in liberated areas have found ways to reassert themselves, most notably by insisting on the right of the local community to appoint its own government. This has pitted local authorities against the TFG, which has insisted on the right to name its own governors across the country. For leaders of local political orders, both al-Shabaab and the TFG are viewed as outside threats

\section{HYBRID GOVERNANCE AND FORMAL STATE STRUCTURES}

In both of the most successful regional states, secessionist Somaliland and autonomous Puntland, traditional authorities - that is, clan elders-have been formally incorporated into government deliberations. The TFG has done the same, employing clan elders as representatives in a national constituent assembly that was tasked with selecting a new parliament and approving a provisional constitution. The most interesting example of "hybrid governance" -incorporating traditional authorities into formal government-has occurred in Somaliland, where elders' roles are enshrined in an upper house, or "guurti," of a bicameral parliament. This was done in part to build popular trust and confidence in the nascent government and in part to influence and co-opt the clan elders. It is this latter dynamic that worries some critics of hybrid governance, who see in it a real danger of manipulation of traditional authorities, leading to a decline in their legitimacy.

A somewhat less controversial form of hybrid governance involving partnership between emerging state authorities and informal authorities can be seen in judicial functions. Throughout the Somali-inhabited East Horn, in- 
cluding eastern Ethiopia and northern Kenya, the vast majority of criminal cases and disputes are handled through either customary or sharia law, not the formal court system. Somalis have a strong preference for compensational rather than punitive justice and have greater confidence in clan elders than in judges and the court system. In Somaliland, Puntland, Djibouti, Ethiopia, and Kenya, this has led to an awkward situation in which whole communities rely on an extralegal, unconstitutional process to handle serious criminal offenses. In a growing number of cases, formal governments are exploring ways to harmonize customary, sharia, and civil legal systems, pointing toward the creation of a hybrid judicial system. In practice, this is already commonplace in Somalia, where clan elders frequently work with local police to arrest and detain criminal suspects.

\section{LOCAL ORDERS AND THE STATE}

The protracted weakness of formal state structures in Somalia, contrasted with the ubiquitous presence of more-effective informal governance systems, raises an unavoidable question: Is there a role these local political orders can play in state-building in Somalia?

There are four different schools of thought on the relationship between informal governance systems and the state.

The first holds that informal governance has no significance to state-building. This has been a dominant view among state-building programs that focus exclusively on formal state institutions and processes in Somalia. For many of these actors, informal political orders are invisible and inconsequential.

The second considers informal governance significant but negative- that is, it poses a threat to state-building. From this perspective, subnational polities and informal political orders are rivals to the state and serve as active impediments to the expansion of state authority. Leaders of local political orders have a vested interest in perpetuating their autonomy and are spoilers that states must overcome. In Somalia, nationalists fear that substate polities are enshrining clan enclaves. Many others object to legitimation of any informal political order that enforces unconstitutional and illiberal laws, noting that both sharia and customary law do not afford equal rights to women and fall well short of due process and other minimal legal benchmarks. This school of thought opposes any proposal to create hybrid political arrangements that include informal authorities.

The third sees informal governance as significant and positive, but temporary. Many observers recognize that in a weak or failed state, informal governance systems are the only source of security and rule of law that millions 
of citizens can count on. This is a view of informal governance as a form of a coping mechanism. Embracing a "Do no harm" ethos, this school of thought argues for policies that recognize and respect informal governance systems during the long interim period required before state-building efforts yield a police force, judiciary, and public administration that the public can trust. At that point, the argument goes, clan elders, customary law, and other features of informal governance will gradually fade in importance.

The fourth school of thought argues that informal governance plays a significant role in the construction of a new, more indigenous "mediated" state in Somalia. Such a role for informal governance systems in state-building is possible only if one conceives of a different kind of central government, one that may not conform to the template derived from Western political institutions. Some argue that Somalia is already embarking down a road toward a new, more indigenous state that involves hybrid governance arrangements not so much out of choice as out of necessity.

Somalia's posttransition government is likely to be very weak for some time to come, and its only means of extending its authority will be to do what it has already done: negotiate relations with nonstate and substate entities in areas beyond its control. This is the so-called mediated-state model, in which a central government that "has the competence to know the limits of its competence" allows local authorities to mediate relations between the state and its citizens, and outsources to the private sector, nonprofits, and local polities many functions normally associated with a central government. The TFG's reluctant relations with subnational polities Puntland and Galmadug, for instance, are vintage examples of a mediated state, as are its tense relations with powerful local politicians in Mogadishu, who are at once members of parliament and warlords preventing the TFG police from entering their neighborhoods. Such a path toward state-building is messy, fluid, conflictual, and not at all amenable to most state-building aid programs. But it is a much more realistic model of how weak states seek to claim, and gradually build, authority over their territories. 



\title{
POSTSCRIPT
}

\author{
INGo TRAUSCHWEIZER
}

Some three years after the conference that brought these scholars together and generated the chapters you have just read, their arguments appear equally timely and pressing. We decided not to update the chapters to reflect events of the past three years in detail; sadly, the general themes and issues remain pertinent and the conclusions remain largely pessimistic. Since the 2011 Baker Peace Conference, the civil war in Syria has widened and taken on horrific dimensions, the revolution in Egypt has turned sour and the political crisis remains to be resolved, the Middle East in general appears no more stable now than it did then, and the same could be said for other regions of the world. As I am writing, South Sudan is in the news. Newsmakers tend to pay attention to poor countries mainly in times of crisis, and they have a hard time keeping up. There are success stories, notably Colombia's war on drugs and insurgents, but crisis seems to be the mode of our time; and failed states and fragile societies remain at the center of crises, either as cause or as effect.

The most pressing question of this moment, in the winter of 2013-2014, is whether the West should intervene forcefully in Syria, even though the recent notion of an American- or United Nations-led military intervention has been set aside in favor of diplomatic efforts. However, it is not at all clear what either diplomatic or military efforts could accomplish in the medium term. In the short term, hardly anyone in the West would object to the ouster of Bashar al-Assad. But then what? The opposition is deeply divided, fragmented even; and regional actors such as Saudi Arabia, Israel, and Iran, as well as global actors such as the United States and Russia, would not find common ground. Moreover, Islamist fundamentalist groups, perhaps only loosely combined under the roof of the "Islamic State of Iraq and the Levant," offer a challenge that 
none of these external powers could find tolerable unless they were invested in an instable Syria that poses a threat to the West and to the global order of the past centuries that the West has underwritten. Surely military intervention, though it may stop the slaughter in the short term, has little to offer by way of hope for a stable Syria. On the other hand, as Robert Rotberg argues, the West has a responsibility to protect the people who are innocent victims. Humanitarian ideals and political and strategic circumstances do not come into ready alignment. Those who favor military intervention on humanitarian grounds need to consider the long-term commitment and ramifications, while those who oppose it have to address whether it is ethical to stand by and watch the deaths of civilians on the evening news.

Similarly, the future of Afghanistan remains in doubt, with the withdrawal of American and NATO forces looming in the near future. Here, too, civil society appears too fragmented to uphold a state in the modern sense of the term. It is very difficult to imagine an Afghan government in Kabul that could hold and maintain a monopoly of violence and enforce law and order in all corners of the country. That could have been said about Somalia, too; yet, as Ken Menkhaus suggests, local structures can fill functions we usually associate with the state, and society can serve as the host of popular sovereignty. What may complicate matters in Afghanistan is that it remains of great concern to its neighbors and thus will be watched closely not only by the United Statesindeed, perhaps least closely by the United States if we took the history of the 1990s for a guide—but also by Pakistan, which has little to gain from a stable Afghan government that may lean toward India and Iran rather than Pakistan and China. Perhaps the Afghan crisis, in one way or another running since the 1970s, has been equally homemade and propelled by external forces. Yet it is safe to say that very little has changed in the long-term outlook on Afghanistan's future since the attempts of the Obama administration to repeat the relative success of the surge of armed forces in Iraq. In Afghanistan that did not work, but even if it had, long-term stability cannot result from military means or even from a more broadly conceived counterinsurgency and nation-building effort, which requires a legitimate national government. In that regard, Afghanistan today bears resemblance to the South Vietnam of the early 1970s.

What these examples show, and what other case studies in this volume underscore, is a crisis in sovereignty and, therefore, a crisis of the modern state itself. As noted earlier, Max Weber's definition of the state no longer applies readily in large parts of the world. Perhaps it never did, since the chronologies of decolonization and failing states appear to overlap in the Cold War era. Western observers were then heavily conditioned to view the world in terms 
of great power confrontation, dating back to a mind-set that took shape not in 1945 but had evolved since the mid-seventeenth century. Western observers today may still be too heavily wedded to the notion that the state makes war and that nonstate actors can be contained by military and political means that seemed to work throughout modern history. What if we are experiencing a transitional age between modernity and whatever may follow? History offers some hope, for after the upheaval of the seventeenth century-global in scale, as Geoffrey Parker points out in a magisterial new study — came relative stability, albeit at great cost as the West amassed wealth and other parts of the world either fell behind or remained underdeveloped. ${ }^{1}$ But no matter one's sense of history, these basic questions remain for present and future: Are failed or failing states and fragmented societies an indicator of flaws in the modern international order that can be fixed? Or are they a sign of things to come? And what past do we turn to for guidance or what other prognosticators do we apply?

\section{NOTES}

1. Geoffrey Parker, Global Crisis: War, Climate Change and Catastrophe in the Seventeenth Century (New Haven, CT: Yale University Press, 2013). 



\section{CONTRIBUTORS}

David Carment is a professor of International Affairs at the Norman Paterson School of International Affairs, Carleton University; and Fellow of the Canadian Defence and Foreign Affairs Institute. His books include Who Intervenes? Ethnic Conflict and Interstate Crisis (Ohio State University Press, 2006, with Patrick James and Zeynap Taydas); and Peacekeeping Intelligence: New Players, Extended Boundaries (Routledge, 2006, with Martin Rudner).

James M. Carter is an associate professor of history at Drew University, where he specializes in American foreign relations, the Vietnam War, the United States and East Asia, the Cold War, modernization theory, political economy, and nation-building. His book Inventing Vietnam: The United States and State Building, 1954-1968 (Cambridge University Press) appeared in 2008.

T. David Curp is an associate professor of history at Ohio University. He is an expert on the contemporary history of Eastern Europe and the Balkans. His book A Clean Sweep: The Politics of Ethnic Cleansing in Western Poland, 1945-1960 (Rochester University Press) appeared in 2006. His essays and articles have appeared in Nationalities Papers, Polish Review, and European History Quarterly.

Vanda Felbab-Brown is Senior Fellow in Foreign Policy at the Brookings Institution. She specializes in international and internal conflicts and their management and nontraditional security threats, including organized crime and illicit economies. Among her many publications are Aspiration and Ambivalence: Strategies and Realities of Counterinsurgency and State-Building in Afghanistan (Brookings, 2013); and Shooting Up: Counterinsurgency and the War on Drugs (Brookings, 2009).

Jonathan M. House is a former career army officer and political-military analyst for the Joint Chiefs of Staff and currently the William A. Stofft Professor 
of Military History at the US Army Command and General Staff College. His books include Combined Arms Warfare in the Twentieth Century (University Press of Kansas, 2001); A Military History of the Cold War, 1944-1962 (University of Oklahoma Press, 2012); and a number of collaborative efforts with David Glantz, most recently, The Gates of Stalingrad: Soviet-German Combat Operations, April-August 1942; and Armageddon in Stalingrad: SeptemberNovember 1942 (both University Press of Kansas, 2009).

Kenneth J. Menkhaus is a professor of political science at Davidson College. His research focuses on development, conflict analysis, peace operations, state failure, state-building, and political Islam at the Horn of Africa. He is the author of more than fifty articles, book chapters, and monographs, including Somalia: State Collapse and the Threat of Terrorism (Routledge, 2004); "Governance without Government in Somalia," in International Security (2007); and "State Fragility as Wicked Problem," in PRISM (2010).

Steven M. Miner is a professor of history and the director of the Contemporary History Institute at Ohio University. He specializes in recent Russian and Soviet history. His books include Between Churchill and Stalin: The Soviet Union, Great Britain, and the Origins of the Grand Alliance (University of North Carolina Press, 1988 and 2010); and Stalin's "Holy War": Religion, Nationalism, and Alliance Politics, 1941-1945 (University of North Carolina Press, 2003).

Robert I. Rotberg is the former director of the Program on Intrastate Conflict, Conflict Prevention, and Conflict Resolution at Harvard University's John F. Kennedy School of Government and president emeritus of the World Peace Foundation. He is the author and editor of numerous books on US foreign policy, Africa, Asia, and the Caribbean, including When States Fail (Princeton University Press, 2003); and Transformative Political Leadership: Making a Difference in the Developing World (University of Chicago Press, 2012).

Yiagadeesen (Teddy) Samy is an associate professor at the Norman Paterson School of International Affairs, Carleton University. Samy, a development economist, has authored numerous publications on aid and development, including a recently coauthored volume on fragile states with David Carment, Security Development and the Fragile State (Routledge, 2009). He and Carment have written articles on fragile states that have appeared in the Journal of Confict Resolution and Conflict Management and Peace Science. 
Ingo Trauschweizer is an associate professor of history at Ohio University. His book The Cold War U.S. Army: Building Deterrence for Limited War (University Press of Kansas) appeared in 2008; and he has published several articles and chapters on modern military history, transatlantic relations, and international security in contemporary history. 

A

Abkhazia, 57

Abu Ghraib, 69. See also Iraq

Afghanistan,

and al-Qaeda, 18-20

and counterinsurgency, 89, 91, 101,

106-7, 112-13

and criminal activities, 96-97, 99, 101, $106-8,110,115$

as failed state, 131

future of, 152

and Global War on Terror, vii, x, 17,

$20,53,59,91,101,106-7$

and government contracts, xiii, 66-68, 77

and India, 12

and mujahideen, 9

and Pakistan, 8-9, 12

and Taliban, 20, 106-7

and Uzbekistan, 127

African Union, 91, 132, 147

Agency for International Development

(AID or USAID), 65-66, 70, 75,

84, 88. See also USAID

airfields, 72-74, 76, 83

airpower, xiv

airstrikes, 91

Aleppo, 136

Al Fallujah, 70. See also Iraq

al-Qaeda

in Bosnia, 36

in Mali, 136

and 9/11 attack, 90

as non-state actors, 57 in Pakistan, 91

in Yemen, 16-20

al-Shabaab, 132, 142, 146-47

American International Contractors, Inc., 67

American Revolution, 50, 54, 60-61

Amin, Idi, 120, 132

Amnesty International, 121

Andaman Sea, 123

An Najaf, 70

Annan, Kofi, 136

Arab League, 129-30

Arab Spring, 35, 101, 119, 124-25,

128-29

Aristide, Jean-Bertrand, 13, 16

arms makers, 77

army

British, 50, 59, 61

French, 56

in insurgencies, 50-51, 59

Iraqi, 66

Libyan, 130

North Vietnamese, 51

Pakistani, 9

US, 49, 59-62, 69, 79-83, 85-86, 88

Yugoslav People's, 30

Army of the Republic of Vietnam, 55

Arusha, 134

Asia-Pacific Theater, vii, 90

Aspin, Les, 63, 64, 79

Assad, Bashar al-, 92, 127, 128, 130,

151

Augustine, Norman, 64, 79, 85

Aung San Suu Kyi, 123, 124 
authority, legitimacy, and capacity (ALC), $5,11,15-16,19,22,25$

Awlaki, Anwar al-, 18

B

Bahrain, 16, 20, 135-36

Bahrain Independent Commission, 139

Baidoa, 132

Balkan wars, 101

Bashir, Omar al-, 131

Battle of Mogadishu (1993), vii

Bechtel Group, 66

Belarus, 122, 126, 130, 134

Ben Ali, Zine al-Abidine, 127

Benghazi, 129, 136

Berdymukhammedov, Gurbanguly, 122

Berna, Don, 95

Bhutto, Benazir, 8

Bin Laden, Osama, 18

Blackwater USA, 66

Bokassa, Jean-Bedel, 120

Bosnia-Herzegovina, v, xi-xii, 28, 41-42, 44-45

Bosniaks, 30, 35-36, 42

Bosnian Croats/Croatians, xi, 30-31, 37, 42

Bouazizi, Mohammed, 35

Bourguiba, Habib, 128

Brown, George R., 75

Brown and Root, 64, 66, 72, 75-77, 80, 83

Burma, xv, 120-24, 129, 135, 137-38, 140

Bush, George W., 58, 66, 67-68, 82, 85

business, $\mathrm{x}, 66,77-78,93,143-44$

businesspeople, 145, 146

C

CACI International, 69

Calderón, Felipe, 94, 109, 110, 113

Cameroon, 129

Carter, Jimmy, x

Castro, Fidel, 52, 120

Center for Public Integrity, 66, 79-80, 85,88

Central Africa, x, 120, 132
Central African Empire, 120, 132

CEOs, 63

Chad, 129

Chávez, Hugo, 14

Chechnya, 31, 41, 46, 90

Cheney, Richard, 64, 66, 68, 79, 88

Chiang Kai-shek, 51

China, 56, 90, 92-93, 122-23, 125, $129-30,135,138,140,152$

CH2M Hill, 67

Ciudad Juárez, 94, 109, 113

civilian(s)

abuses against, 134, 152

aid, 19

attacks on, 129, 133-34

casualties, 54

counterparts to military, 106

distinction between combatants and, 90

purposes, 35

resources, 62

state, viii

targets, $\mathrm{x}$

vulnerability, 91

workers, 80

civil war,

American mitigation efforts, 90

in Bosnia, 28-30, 40, 42, 46

in China, 51

in Colombia, 90

economic causes of, 108, 113

in Greece, 51

in Karachi, 93

in Libya, viii

as "man-made" calamity, 3

peacekeeping operations in, 101, 132

in relation to other sources of violence and instability, 6

in Syria, viii, xv, 129, 151

in Yemen, 16, 18

Clausewitz, Carl von, 52, 59, 61

client state, $8,17,130$

Clinton, Bill, 31, 63, 79

Clinton, Henry, 53, 59

Clinton, Hillary, 19, 123, 124, 136, 138, 140 
Coalition Provisional Authority (CPA), 69

Coke, Christopher "Dudus," 95, 110

Cold War

containment, 72

and corporations, 64, 72, 78

decolonization and failing states during, 152

and military-industrial complex, xiii, 63-64

nature of, ix, $x$

post-Cold War, vii-viii, xiii, 6, 39,

63-64, 89-91

collapse

of foreign aid, 13

of fragile states, xi, 19

of Guatemala’s judicial system, 96

of legitimacy, ix

of order, 106

of peace processes, 101

of regime, viii, xiv, 57

of Somalia, 131, 142-43

of state, v, xii, xiv-xv, 3, 5, 119, 131, $137,140,142-43$

Colombia, xiv, 90, 94-96, 110,114, 151

colonialism, vii-viii, 53, 55, 58

combat

interstate, 133

in Iraq, 76

mechanized, 50, 56

potential US-Iranian, 89

combatants, xii, 90

Communists

Chinese, 51-52

Greek, 51

Vietnamese, xii, 55

compound warfare, xii, 50-51, 56, 59, 61

Congress (US), 41, 44, 65, 67-68, 70, 74, 80-81, 84-86

Congress of Westphalia, 135

corruption perceptions index, 14, 121

cost-benefit analysis, 107-8

Côte d'Ivoire (Ivory Coast), 103, 124, 129, 131, 136

counterinsurgency

in Afghanistan, 40, 91, 101, 107, 152

in Colombia, 90, 95 costs of, 55

and crime, 104-7, 111

in Greece, 55

and Internet and electronic devices, 56

and Israeli Defense Forces, 56

in Malaya, 55

methods and theories, xii, 52, 54-56,

58-60, 99, 104-5

in Pakistan, 91

as response to instability, xii, xiv

and United States, 55, 59, 89-91

in Vietnam, 51, 55, 59

See also insurgency

counternarcotics, 104

counterterrorism, xiii, 90-92, 101, 103

Country Indicators for Foreign Policy

(CIFP) project, 4, 8-9, 25-27

crime

atrocity crimes, 134, 136, 138-41

against civilians, 134

conflict nexus, 104-5

financing, 15

in fragile states, 22, 25, 98-99

in Haiti, 15

against humanity, 133-36

in Karachi, 93

in Latin America, 110

and low-intensity conflict, 89, 93, 100

organized, 14, 31, 97, 99, 100, 102,

105, 107, 109-13

in postconflict country, 101-2

responses to, xiv, 93-108

street, 99-101, 105

syndicates, $\mathrm{x}$, xiv

and terror, 103

terror nexus, 103

in Vietnam, 74

victims of, 144

war, 35, 134

war on, xvi

Croatia, 28, 30-31, 37, 40, 43, 46. See also

Bosnian Croats/Croatians

Custer Battles (company), 69

cyber

attacks, 91

sabotage, 91 
cyber (continued)

space, xiv

war, 92

D

Darfur, 131-32, 135

Dayton Accords (1995), xii, 29, 31, 34-35, 40, 45

decolonization, 50, 152

democratization, 11, 19, 126

demodernization, 31-32

Department of Defense, 49, 66, 81

Department of State, 49, 123

desecularization, 36-37, 43-44

Desert Storm campaign, 90

Deutch, John, 79

Djibouti, 148

Doctors without Borders, 121

Dodik, Milorad, 34, 41, 42, 46

drug trafficking organizations (DTOs), 94

Dubai process, 12

Duke of Wellington, 50

Duvalier, François (Papa Doc), 120

Du Yuesheng, 100

DynCorp, 66, 77

E

economic

activities, 15, 17, 97

agendas in civil wars, 108

assistance (to South Vietnam), 88

aid, 74

capacity, 3-5, 17

causes of civil war, 108, 113

corruption, 38

decline, viii, xiv, ix

distribution of power, 105

environment, 99

experts, 105

functions of violence, 114

growth (development), ix, 7, 13-14,

16-17, 21-23, 26, 32, 84, 96, 100

impact (of Vietnam War), 85-86

incentives, 107

inflation, 74

infrastructures, 123 instability, xi, 20

networks (illegal), 104

opportunity, 26, 98, 128

performance, 15-16, 25

policies, 15

power, 55, 126

Priorities (Council on), 84

problems, 13, 20

production (illegal), 100

profit motivations, 90

prosperity, 91

reform, 31

sanctions, 93

survival, 99

thought, 127

unrest, 57

See also economy

Economic Community of West African

States (ECOWAS), 132

economy

Bosnia's, 33

drug, 97, 101, 110

formal, 13

of fragile states, $x i$

illicit, 96-99, 101-2, 104-5

informal, 7

Iraqi, 68

legal, 104

mismanaged, 3

political, 40, 44, 79, 86

postcolonial, 58

shadow, 74

troubled, 12,16

US, 78

US aid, 75

See also economic

Egypt, viii, 16, 20, 53, 56-57, 101, 122, $124,127-30,151$

election(s)

in autocratic or authoritarian states, 24

in Belarus, 126

in Bosnia, 34

in Burma, 123, 129

in Côte d'Ivoire, 136

in Haiti, 22-23 
in Jamaica, 110

in Pakistan, 11

postelection killings in Kenya, 136

in Tunisia, 128

in Yemen, 19

in Zimbabwe, 124-25

See also reelection

embargoes, 30-31, 101

Equatorial Guinea, 112, 115, 120, 122, $125,129,132,138,140$

Eritrea, 129

ethnic-cleansing projects, xii

ethno-national, 34, 36, 40

European Union, 29, 33, 37-38, 40, 44, $46,91,130$

extralegal,

power brokers, 105

unconstitutional process, 148

\section{F}

Facebook, 56. See also social media

Fajardo, Sergio, 95

favelas (slums), 94, 109-10, 112, 114

First World War, xvi-xvii, 68

Fluor Corporation, 67, 77

fragile states,

aid toward, 24

assessment of, 21

disorder in, 7

Haiti as a, 3, 8, 12, 15, 22

insurgencies within, 53

and legitimacy problem, 7

malleability of term, xi

in Middle East, 4, 20

Pakistan as a, 3, 8-9, 12

populations in, 5

rebuilding, 21

recommendations for policymakers about, 24-25

similarities, xi

in South Asia, 4

in sub-Saharan Africa, 4

and violence, 6

what constitutes, xi, 3-4

Yemen as a, 3, 8, 20

France, 127-32, 136
G

Gadhafi, Mu'ammar, 19, 52, 92, 105, 126, 129-31, 136

Galmadug, 149

Gates, Robert, 56, 60-61

Gaza Strip, 57

Gbagbo, Laurent, 124, 134, 136

Geneva Conventions (1949 and 1977), 133

Genocide Convention (1948), 133

Germany, 79, 86, 128

Ghana, 103

Global War on Terror, 8, 10. See also

Afghanistan; Iraq

Gnassingbé, Faure, 125-26

Golding, Bruce, 95

Goma, 132

Government Accountability Office

(GAO), 70

Government of National Unity, 124

gross domestic product (GDP)

of Afghanistan, 97

and basic human rights and good governance, 122

of Bosnia, 33

of Haiti, 12, 14

as measure of capacity, 6

of Sinaloa (Mexico), 97

of Yemen, 17

Grupamento de Policiamento em Áreas

Especiais (GPAE), 94

guerrillas, xii, 50-53, 59-61, 95

Guevara, Che, 51

Guinea-Bissau, 102

Gulf states, 17

Gulf War, 71, 90. See also Iraq

$\mathbf{H}$

Hague, The, 124, 133-34

Conventions of 1899 and 1907, 133

Haiti, xi, 3, 8, 10, 12-16, 23, 26-27, 56, 96,120

Halliburton, 66, 68-69, 77, 79-82, 85-87

Hama, 136

Hamas, 57

Hamdi, Fadia, 35 
Hasan-e Șabbāḥ, 50

health care, $14,18,74,98,100$

Hemispheric Opportunity through

Partnership Encouragement

(HOPE) Act, 13

Hezbollah, 56-57, 89

high representative, 30-32, 34, 37-38

HIV/AIDS, 5

homeland, 15, 90

Homs, 136

human development index (HDI), 12, 122

humanitarian

aid, $\mathrm{x}$

crises, 146-47

extremism, 30

ideals, 152

instincts, viii

intervention, xi-xii, xvi-xvii, 38, 91, 100, 103, 135

realpolitik, 31

human rights

appeal of, xiv

challenge posed to, xii

in Belarus, 126, 130

in Bosnia, 28-29

in Burma, 123, 129

in Equatorial Guinea, 125

in fragile or failed states, 7, 120, 122, 131

intervention in the name of, xii, 132

in Laos, 132

in Pakistan, 10

regime, viii, xii, $x v$

and Report of the International

Commission on Intervention and

State Sovereignty, 91

in Saudi Arabia, 21

in Somalia, 146

and state legitimacy, 8

in Syria, 127

in Tunisia, 21, 127

in Turkmenistan, 130

in Uzbekistan, 127, 130

in Yemen, 3

Human Rights Watch, 121

Hussein, Saddam, 65-66, 69, 90, 101, 120

hybrid warfare, 56, 60
I

Iberian Peninsula, 50

illegal

behavior, 99

contracts, $68,75,80$

currency manipulations, 84

economies, 98, 100, 102-4

fishing, 102

poppy cultivation, 108

reentering countries, 15

illiberal, 143, 148

Indo-Chinese, 55

insurgency

actors in, 54

in Afghanistan, 40, 91, 101, 107, 152

in Colombia, 90, 95

and crime, xiv, 93, 104-7

forms of, 49, 55-57

future of, 57-59

in Greece, 55

in Iraq, 58, 70

isolated, 55

and Israeli Defense Forces, 56

in Malaya, 55

in Pakistan, 91

theories of, 50-52

and United States, 55, 59, 89-91

in Vietnam, 51, 55, 59

See also counterinsurgency

international community, 39, 41-42, 44, $101,102,105,107-8,137$

International Covenant on Civil and

Political Rights, 120

International Covenant on Economic,

Social, and Cultural Rights, 120

International Criminal Court (ICC), 124-26, 129, 133-34

International Network for Children and

Families (INCAF), 24

International Tribunals for Former

Yugoslavia and Rwanda, 133

Internet, 56, 121, 125

Inter-Services Intelligence (ISI), 94

interstate

transportation, 69

war, x, xiv, 89-90, 92, 133 
intrastate warfare, $x, 93,133$

Iran, 31, 36, 42, 56, 71, 89, 92-93, 120, $122,129,151-52$

Iraq

army of, 50, 66

contract work in, xiii, 63, 65-71, 76-77, 79-82

corruption in, 69

insurgency in, 58-59, 89-91

Iraqi Freedom, Operation, 90

Islamist fundamentalists in, 151

post-invasion state-building, 65-71, 79

and Saddam Hussein, 65-66, 69, 90,

101,120

war in, vii, xiii, 19, 56, 58-59, 65, 71, 152

Irrawaddy River, 123

irregulars, 50, 54

Islam

in Balkans, 43, 46

Bosnian, 36, 42

radical, 42, 46

Wahabi interpretation of, 52

in Yugoslav successor states, 43, 45

See also Islamic; Islamists

Islamabad, 57

Islamic

Courts Union, 90

networks, 46

radicalization, 36

revival in post-Socialist Bosnia and

Herzegovina, 43-45

social and cultural activism, 36

Union of Islamic Courts, 132

See also Islam; Islamists

Islamists

in Mali, 136

regime (radical), $\mathrm{xv}$

in Somalia, 90, 146

in Syria, 151

in Tunisia, 128

in Uzbekistan, 127, 137

See also Islam; Islamic

Israel, 56-57, 89, 151

Israel Defense Forces (IDF), 56

Izetbegović, Alija, 30, 40, 42

\section{J}

J. A. Jones Construction, 72, 83

Jamaica, xiv, 26-27, 94, 95, 110, 112, 115

jihad, 42, 46, 142

jihadism, 90, 146

jihadists,

as a general label in counterinsurgency, 58

in Mali, 136

recruitment, 36

in Yemen, 18

Johnson, Lyndon B., 76

judicial

functions, 147

independence, 121

institutions, 32

reforms, 110

system, 14, 96, 148

junta, 122-24

K

Kachin, 137

Kamchatka, 39

Karachi,11, 93-94, 109, 114

Karadžić, Radovan, 35

Karimov, Islam, 127

Karzai, Hamid, 106-7

Kashmir, 9

Kazakhstan, 129, 132

Kellogg Brown and Root, 66, 80

Kekic, Laza, 33, 41, 45

Khalifa, Hamad bin Isa al-, 136

Khomeini, Ayatollah, 120

Kim Jong Il, 120, 126-27

Kinshasa, 131

Kismaayo, 132, 146

Kosovo, xii, 31, 33-34, 37

Kurdistan, 136

Kyrgyzstan, 128

L

land-grabbing, 93

law

and order, xv, 142-44, 147, 152

customary, xv, 144, 148-49 
law (continued)

enforcement, 93-94, 96, 98-100, 103, $107,111,113-14$

illiberal, 148

imposition of, 32

international, 5, 38, 79, 88

natural, 122

rule of, ix, 3, 6-7, 17, 21, 33, 102,

111-12, 115, 120-21, 131, 144, 148

sharia, 144,148

vacuum of, 79, 81, 84, 88

See also legal; illegal; extralegal

Lawrence, T. E., 50

legal

benchmarks, 148

businesses, 93

drug economy, 97

economy, 98, 100, 102, 104

employment (livelihood), 98-100, 104

government, 54

international imprimatur, 35

issues, 33-35

rulings, 125

systems, xii, 7, 14, 134, 148

territory, 6

See also illegal; extralegal

Lesotho, 132

libertarian, 143

Long March, 100

Loyalists (British), 54

Lukashenko, Aleksandr, 126-27

M

macroeconomic, 13

Mad Max anarchy, 143

Malaya, 55

Mali, 103, 119, 131, 136. See also northern Mali

Mao Tse-tung, xii, 50-52, 59, 61, 100

Marian shrine, 37

Marion, Francis, 50

Marxism-Leninism, 18, 49

mass-atrocity crimes, 134, 136

Matryoshka doll, 28
Mbasogo, Teodoro Obiang Nguema, 120, 124-26

Medellín, 94-94, 110, 114

Medjugorje, 37

Mercy Corps, 121

microcredit, 100

microeconomic, 97

military

aid, 9, 19, 73-74

apparatus, 8-9

assistance, 19, 55, 84

commanders, xiv

and defense contractors, xiii, $62-88$

effort(s), xiii, 90, 151

equipment, 130

expenditures, 7

force(s), xiv-xv, 29, 39, 67, 94-95,

100, 104, 106, 137, 139, 141

intervention, ix, xiii-xiv, 91, 135,

151-52

missions, xiii

and "new wars," vii

operation(s), ix, 41, 44, 64, 90, 101,

106

professional, ix

revolution, xvi-xvii

spending, 18,78

superiority, 9

threats, viii

victory, 31, 130

Military-Industrial Complex, v, xiii, 62$64,77,79,87$

militia, xv, 6, 50, 54, 128, 142-44,

$$
146-47
$$

Millennium Development Goals (MDGs), 5,10

Miloševi, Slobodan, 29, 31

ministate, 28

Mladić, Ratko, 35

Mogadishu, vii, 132, 142, 145-46, 149.

See also Battle of Mogadishu;

Somalia

money laundering, 69, 110

Mostar bridge, 37

Movement for Democratic Change

(MDC), 124-25 
M23 rebel movement, 132

Mubarak, Hosni, 19, 130

Mugabe, Robert, 120, 124-26, 131, 134, 137-38, 140

Mujahideen, x, 9, 36

Muslim-Croat, 28, 40, 46

$\mathbf{N}$

Napoleonic Wars, 50

National Security Council, 65, 136

nation-building, xii-xiii, 8, 63, 71-72, 74, $79,82,86-87,152,155$

nation-state, vii, xiv, 55, 75, 119-22, 127, $135,137,140$

Ne Win, 124

New Iraqi Army (NIA), 66

Niyazov, Saparmurad, 120, 122, 126

nongovernmental organization (NGO), ix, 28-29, 35-38, 140, 145

nonstate actor, vii, 6, 57, 89-92, 95-96, 99, 111, 114, 131, 133, 149, 153

nonviolent, 129, 138-39

North Africa, xv, 20, 22, 127

North Atlantic Treaty Organization (NATO), x, 29, 31, 39-40, 53, 91, 101, 105, 129-30, 136, 152

northern Mali, 136. See also Mali

Northrop Grumman, 66, 77

North Vietnamese Army, 51

North Waziristan, 10. See also South Waziristan

North-West Frontier Province, 10

Nuba Mountain, 131

Nuremberg Tribunal, 133

O

Oder River, 39

Office of the High Representative, 30-31, 34, 37-38

offshore, xiv, 91, 105, 125

Organization for Economic Cooperation and Development (OECD), 23, 33

organized-crime groups, 99, 107, 111

Ossetia, 57

Ouattara, Alassane, 136

overpopulation, 21
P

patriot, 39, 54, 124

peace-building, 28, 31-32

Peace Implementation Council (PIC), 32

peacekeeping, vii, xiv, 41, 44, 78, 91, 101, 103-5, 107, 111, 113, 132, 155

peacemaking, vii, 29, 35

Perry, William, 79

Peters, Ralph, 53

piracy, x, 99, 101, 108

police

in Afghanistan, 67

in Bosnia, 31

in Brazil, 94, 109, 112, 114

in Columbia, 94-95

in Iraq, 66-67, 70

in Jamaica, 94-95

in Mexico, 94, 110

military police, 105

in Pakistan, 57

paramilitary police, 59

police force, 100, 105, 121, 125, 144, 146, 148-49

police man and/or woman, 35, 54

police state, 128

reform, 100

secret police, 127

policymakers, vii, xi, xiv, 4, 7-8, 24, 31

Pol Pot, 120, 126, 132

Port-au-Prince, 14

post-Cold War

era, viii, 78

policies, 39

See also Cold War

postconflict, 32-33, 40, 101-2

postinvasion, 65-66

postwar, xvi-xvii, 29-31, 44, 65-67

power brokers, 31, 1046, 124

prewar, 31

Primero comando da capital, 99

Privatized Military Firms (PMFs), 79, 88

protesters

in Bahrain, 136

in Belarus, 126, 134-35

in Egypt, 136

in Syria, 129, 134-36 
protesters (continued)

in Tunisia, 136

in Yemen, 129-30, 136

protostates, 99

Puntland, 99, 146-49

Q

Qatar, 129-30, 135

$\mathbf{R}$

rapporteurs, 121

Raymond International and Morrison-

Knudsen (RMK), 72, 75, 82-83

Reagan, Ronald, x, 64

realpolitik, 31, 138, 140

reelection, 13. See also election

regime ancien, 105

relief

efforts, 70

organizations, 36, 121-22

repressors, 54, 120, 122

Republika Srpska, 28, 33-34, 37, 40, 42

responsibility-to-protect (R2P) intervention, $\mathrm{xv}, 91,119,133$

Revolutionary Armed Forces of Colombia (FARC), 95

Rome Statute of the International

Criminal Court, 133-34

Rumsfeld, Donald, 65-66, 75, 81

Russia,

and Belarus, 126

and China, 93, 129-30, 135

and freedoms, 129-30

non-Russian groups, 52

occupation of Afghanistan, 9

Russia-Georgian conflict, 56-57

and Syria, 151

and Tajikistan, 131-32

and United Nations, 134-35, 151

Rwanda, 90-91, 131, 133-34, 138-39

$S$

Saada region, 18

Salafi, 90

Salazar, Alonso, 95,

Saleh, Ali Abdullah, 17-20, 130
Sanaa, Yemen, 18, 136

São Paulo, 94, 99, 109, 113-14

Sarajevo, 28-30, 111-12

seaports, 83, 143, 145

Second World War, vii, 39, 50, 52, 63, 100

secretary of state, 19, 123, 136

Seko, Mobuto Sese, 126

Sells, Michael, 37, 43, 46

semi-protectorate, 31-32

September 11, vii, 9, 20, 52, 90

Shan, 137

shantytowns, 94, 99

sharia, 144, 148

Shia, 135. See also Shiite

Shiite, 16, 18, 50

Shining Path, 100

Sinaloa, 97

Social Democrat, 34

social media, 56, 125-26, 130. See also

Facebook

socioeconomic,

goods, 98-99

policies, 100, 111

services, 98

structures, 105

sociopolitical, ix, 31

Somalia

and African Union, 132, 147-48. See also African Union

and business, 145

diaspora, 145-46

local politics, 142-44, 148-49

and piracy, 108. See also piracy

and radicalism, 90-91, 132146

and rebel groups, viii, 90-91, 142

and stability, $\mathrm{x}, \mathrm{xv}, 5,132,142-43$

state-building, 148-49

and United Nations, 100, 143

and United States, 56, 100

Somali Institute of Management and

Administration Development, 145

Somaliland, 145-48

South China Sea, 92

Southern African Development

Community (SADC), 125, 132 
South Vietnam

and Afghanistan, 152

government, 54

and insurgency, 55

military construction, 83-84, 86, 88

nation-state, 75

and Tet offensive, 51

South Waziristan, 10. See also North

Waziristan

spillover, 93, 97

Srebrenica, 29

Sri Lanka, 9

Stalin, Joseph, 52, 156

state-building

in Afghanistan, 101

in Bosnia, 32-41, 45-46

and combating crime, 99

corporations, 7

risks to, 21-23, 106

in Somalia, 148-49

statelet, 28

in Vietnam, 71-76

State Peace and Development Committee, 122-23

strongmen, 142

sub-Saharan Africa, xi, 4, 20, 130

substate, 148-49

sugarcane, 13

superpower, 90

suzerainty, 130

Swaziland, 129

\section{$\mathbf{T}$}

Tajikistan, 131-32

takfiri terrorism, 49

Taliban, 10, 20, 57, 91, 106-7, 112, 115

taxpayers, 10

Taylor, Charles, 101

terrorism, xiv, 6-7, 26-27, 49, 60, 90, 93, 100-1, 103, 112-14, 156

Tet offensive, 51

text messaging, 130

Thailand, 9, 131-32, 138, 140

Than Shwe, 123-24, 139, 140

Thein Sein, 123

Third World, x, xvi-xvii
Timor-Leste, 132

Tishkov, Valery, 31, 41, 46

Tito (Marshal), 33

Tivoli Gardens, 95

Togo, 103, 122, 125-26, 129, 138, 140

transitional federal government (TFG), $142,146-47,149$

Transparency International, 121

Tsvangirai, Morgan, 125

Tuđman, Franjo, 29-31, 40

Turkistan, 120

Turkmenistan, 122, 125-26, 129-30, 132

U

Uighurs, 137

UN (United Nations),

and Bosnia, 29-31, 37

Development Program, 26-27, $121-22$

General Assembly, 139

International Commission against Impunity in Guatemala, 96-97, 110-11, 115

Office on Drugs and Crime

(UNODC), 110-11, 115

and peacemaking, vii

post-Cold War policies, 39-40, 137

Protection Force (UNPROFOR), 37-38

Security Council, 134, 136

and Somalia, 143

World Summit 2005, 135

and Zimbabwe, 125

Unidade de Policía Pacíficadora (UPP), 94. See also Grupamento de Policiamento em Áreas Especiais (GPAE)

Union of Islamic Courts, 132

United Arab Emirates (UAE), 130

United States

and Afghanistan, vii, 19, 53, 67-68,

$77,91,101,106-7,127,152$

and Bosnia, 28, 31, 41

and counterinsurgency, 52-57, 89-91, 101

and crime, 15, 49, 58, 89, 93-106, 110 
United States (continued)

and drug trafficking, 49, 93-102, $107-8,110$

and interstate war in the twenty-first century, 55-57, 90-92

intervening in civil wars, viii-x, 28 , 136-37, 151

intervention in Libya, 19, 92, 105, 130,136

and Iraq, 65-71, 77, 91, 101

and NATO, 40, 53, 91, 101, 105,

129-30

and Saudi Arabia, 130, 151

and September 11, vii, 9, 90

and terrorism, vii, 10, 18-20, 57-59,

$90,103-7,128$

and United Nations, 31, 40, 137

in the Vietnam War, xiii, 51, 54-55,

$59,63,71-78,83-84,88$

way of war, vii-viii, xiii, 50-51, 55, 57,

59, 63-64, 71-72, 89, 91

Uribe, Álvaro, 95

USAID (US Agency for International

Development), 65-66, 68, 70, 75, 84,88

USS Cole, 18

Uzbekistan, 122, 126-27, 129-30, 132, 137-38, 140

V

Verheugen, Günter, 29, 40, 46

vetoes, 134

Vietcong (VC), 51, 83, 85

Vietminh, 51

Vietnam Builders, 73, 77, 83

Vietnamese

communists, xii, 55

laborers, 72-73, 76

nationalists, 72

North Vietnamese Army, 51

refugees, 84,86

South Vietnamese government, 54

workforce, 83

Vietnam War, xii, xiii, 60, 61, 63, 77, 82-88, 155

Vinnell Corporation, 66, 69
W

Wahhabi sect, 52

warlords, viii, x, 91, 99, 101, 106-7, 111, $115,129,131-32,143,149$

War on Terror, 8,10

wartime, 30-31, 33

war-torn, 41, 46, 90, 146

Washington Group International, 66, 72, 77

watchdogs, 67

Waxman, Henry, 68, 80-81

Waxman, Matthew C., 81, 139, 141

Weber, Max, vii, 125, 152

Weiner, Myron, 9, 26-27

Wellesley, Arthur, 50

West Africa, 102-3, 111-15, 125, 132

West/Western

and Bosnia, xii, 29-30, 42-43

commentators, 52, 152-53

community, 39-41

economic prosperity, 91

and empire-building, vii

governments, 91, 149

and Libya, 130, 136

policies and policymakers, vii, 29, 149

states' monopoly on violence, vii

and Syria, 151-52

and threats to international order, viii

Western forces, 50, 54, 56

and World War II, 39

and Yemen, 18

Wikileaks, 35

workforce, 72-73, 83

World Health Organization, 122

World War I, xvi-xvii, 68

World War II, vii, 39, 50, 52, 63, 100

Y

Yemen

economy, 17-19

legitimacy challenges, 8, 17

political authority, 17

and protests, 124, 128-30, 136

and stability, $\mathrm{x}-\mathrm{xi}, 3,8,16$

taxation system, 17

and terrorism, 17 
Yugoslavia, viii, xi, 30-32, 36, 39-42, 44, 46, 133-34

Yugoslav People’s Army (JNA), 30

Z

Zagreb, 30

Zimbabwe, xv, 24, 120, 122, 124-25, 129,

131-32, 134-35, 138, 140
Zimbabwe African National Union-

Patriotic Front (ZANU-PF),

124-25

Zinni, Anthony, ix-x, xvi-xvii, 28, 35, 42,46 


